\title{
REVITALIZING ENVIRONMENTAL FEDERALISM
}

\author{
Daniel C. Esty* \\ INTRODUCTION
}

Politicians from Speaker Newt Gingrich to President Bill Clinton, cheered on by academics such as Richard Revesz, are eagerly seeking to return authority over environmental regulation to the states. ${ }^{1}$ In the European Union, localist opponents of environmental decisionmaking in Brussels rally under the banner of "subsidiarity."2 And in debates over international trade liberalization, demands abound for the protection of "national sovereignty" 3 in environmental regulation. All of these efforts presume that a decentralized approach to environmental policy will yield better results than more centralized programs. This presumption is misguided.

While the character of some environmental concerns warrants a preference for local control, a sweeping push for decentralized regula-

* Yale Law School and Yale School of Forestry and Environmental Studies; formerly Deputy Chief of Staff and Deputy Assistant Administrator for Policy, Planning and Evaluation at the U.S. Environmental Protection Agency. A.B. 1981, Harvard; M.A. 1983, Oxford; J.D. 1986, Yale. - Ed. Thanks to Bruce Ackerman, Akhil Amar, Richard Andrews, Steve Charnovitz, André Dua, Robert Ellickson, William Eskridge, William Fischel, Damien Geradin, Michael Gerrard, Michael Graetz, Howard Kunreuther, Reid Lifset, Roberta Romano, Carol Rose, James Salzman, Josh Sarnoff, Peter Schuck, Peter Swire, and Jonathan Wiener for comments on earlier drafts. Thanks to Jamie Art, Georgie Boge, Katie Genslea, Karen Krub, Todd Millay, Shalini Ramanathan, and Will Wade-Gery for research assistance.

1. See, e.g., Bill Clinton, State of the Union Address (Jan. 24, 1995), in WEEKLY Compilation of Presidential Documents, Jan. 30, 1995, at 99; Contract WITH AMERICA 133 (Ed Gillespie \& Bob Schellhas eds., 1994); NEwT GINGRICH, TO RENEW AMERICA 9 (1995); Richard L. Revesz, Rehabilitating Interstate Competition: Rethinking the "Race to the Bottom" Rationale for Federal Environmental Regulation, 67 N.Y.U. L. REv. 1210 (1992); see also John H. Cushman, Jr., Senate Panel Votes to Cut E.P.A. Budget, N.Y. Times, Sept. 12, 1995, at A21; Jane Fritsch, Threat to Cut E.P.A. Budget Reflects a New Political Shift, N.Y. TIMES, Aug. 24, 1995, at A1.

2. See, e.g., Cliona J.M. Kimber, A Comparison of Environmental Federalism in the United States and the European Union, 54 MD. L. REv. 1658 (1995); Koen Lanaerts, The Principle of Subsidiarity and the Environment in the European Union: Keeping the Balance of Federalism, 17 FORDHAM INTL. L.J. 846 (1994).

3. See Joel P. Trachtman, L'Etat C'est Nous: Sovereignty, Economic Integration and Subsidiarity, 33 HARV. INTL. L.J. 459 (1992); Steve Charnovitz, Environmentalism Confronts GATT Rules, J. WORLD TRADE, Jan. 1993, at 37. 
tion cannot be justified. Not only are some problems better dealt with on a national (or international) basis, but each environmental issue also presents a set of subproblems and diverse regulatory activities, some of which are best undertaken centrally. While the current decentralization rage represents thinking that has come full circle in the past thirty years, ${ }^{4}$ this article urges not another 180-degree turn but rather a break with unidirectional conclusions about the proper governmental level for environmental policymaking. In trying to stabilize the "environmental federalism" debate, ${ }^{5}$ I argue that what is required is a multitier regulatory structure that tracks the complexity and diversity of environmental problems.

Part I reviews how environmental protection efforts can go awry. ${ }^{6}$ It makes clear that under the environmental rubric falls a diverse set of public health and ecological harms that range widely in scope, duration, severity, and ease of prevention or abatement. It also shows that each separate regulatory problem presents a unique set of technical and analytic challenges, potential "structural" or jurisdictional mismatches encompassing important "choice of public" questions, and public choice

4. From a presumption that environmental problems were largely a state or even a local matter, the pendulum swung in the 1960 s and 1970 s to a conclusion that many issues required centralized policy responses. However, arguments in favor of a more decentralized regulatory structure have been advanced since the enactment of the first national environmental regulatory programs in the United States. See, e.g., C. Boyden Gray, Regulation and Federalism, 1 YALE J. ON REG. 93 (1983); Wallace E. Oates \& Robert M. Schwab, Economic Competition Among Jurisdictions: Efficiency Enhancing or Distortion Inducing, 35 J. PUB. ECON. 333 (1988); Revesz, supra note 1; Harry N. Scheiber, American Federalism and the Diffusion of Power: Historical and Contemporary Perspectives, 9 U. TOL. L. REV. 619 (1978).

5. The term "federalism" has been ascribed more than one meaning. In some uses, it implies a structure of shared power among national, state and local levels of government. See Morton Grodzins, Centralization and Decentralization, in A NATION OF STATES 1, 21 (R. Goldwin ed., 1963). But see Scheiber, supra note 4. In other contexts, federalism (or more particularly "new federalism") is used to suggest a governmental structure with power decentralized away from national authorities. For an introduction to environmental federalism, see Robert V. Percival, Environmental Federalism: Historical Roots and Contemporary Models, 54 MD. L. REv. 1141 (1995). Given the current sweeping support for environmental devolution, my argument for a balance between centralization and decentralization, of necessity, devotes considerable attention to rebutting the claims of decentralizers. But this focus should not be mistaken for support of a presumption in favor of centralized regulation.

6. Environmental policies often fall short of society's goals and expectations. But the argument for state-based regulation cannot rest solely on the claim that federal environmental programs have functioned poorly. Instead, the policy flaws in federal environmental programs must be specified and the logic of state regulation identified. Indeed, to sharpen the focus of this article, I stipulate at the outset to the need for better environmental policy tools and strategies - especially more use of market mechanisms. This article thus seeks to explain how and why we suffer regulatory failures and to examine whether decentralization will ameliorate these problems. 
concerns. Simplistic notions of regulatory reform - including attempts to establish a single, appropriate level of governmental intervention are doomed to fail. Grounded in the hard realities of environmental policymaking, Part I sets the stage for later arguments highlighting the significant degree to which current decentralization theory assumes away the very issues that make regulatory intervention necessary in the environmental domain.

Part II describes the environmental federalism debate to date. It reviews the political arguments made in support of national environmental laws in the late sixties and early seventies, including Professor Richard Stewart's influential 1977 articles $^{7}$ advancing the theoretical case for federal regulation. It then turns to the abundant "second-generation" environmental federalism literature that questions many of the claims about the advantages of federal regulation that underlie "firstgeneration" thinking. Building on Charles Tiebout's seminal analysis of jurisdictional competition, it considers the work of William Fischel, Wallace Oates and Robert Schwab, and the recent work of Richard Revesz and many others who argue that decentralized environmental regulation offers significant social welfare advantages over more centralized policymaking. ${ }^{8}$ Some commentators go so far as to argue that decentralized regulation should be considered "presumptively beneficial." 9

7. See Richard B. Stewart, The Development of Administrative and Quasiconstitutional Law in Judicial Review of Environmental Decisionmaking: Lessons from the Clean Air Act, 62 Iowa L. Rev. 713 (1977) [hereinafter Stewart, Development]; Richard B. Stewart, Pyramids of Sacrifice?: Problems of Federalism in Mandating State Implementation of National Environmental Policy, 86 YALE L.J. 1196, 1210-20 (1977) [hereinafter Stewart, Pyramids]; see also SuSAN Rose-ACKerMaN, Pollution and Federalism, in Controlling Environmental Policy: The Limits of Public LAW IN GERMANY AND THE UNITED STATES 37-54 (1995) (refining the case for regulatory federalism).

8. See Charles M. Tiebout, A Pure Theory of Local Expenditures, 64 J. PoL. EcoN. 416 (1956); William A. Fischel, Fiscal and Environmental Considerations in the Location of Firms in Suburban Communities, in FISCAL ZONING AND LAND UsE Controls 119 (Edwin S. Mills \& Wallace E. Oates eds., 1975); Oates \& Schwab, supra note 4; Revesz, supra note 1; see also WILliam J. BAUMOL \& WALlaCE E. OATES, THE TheORY OF ENVIRONMENTAL POlicy (2d ed. 1988); Gingrich, supra note 1; Jagdish N. Bhagwati, Trade and the Environment, AM. ENTERPRISE, May/June 1993, at 42; James E. Krier \& Mark Brownstein, On Integrated Pollution Control, 22 ENVTL. L. 119, 126-27 (1992); James E. Krier, The Irrational National Air Quality Standards: Macro- and MicroMistakes, 22 UCLA L. REV. 323 (1974); John Cushman, Senator, in Fury, Advances Regulatory Bill, N.Y. TIMES, Apr. 28, 1995, at A16.

9. See Revesz, supra note 1, at 1253; see also GINGRICH, supra note 1, at 9. Even politically "moderate" groups, such as the Democratic Leadership Council, have made a presumption in favor of decentralization a central tenet of their reform proposals. See Debra S. KNOPMAN, Second Generation: A New Strategy fOR EnViron- 
Part III critiques the second-generation orthodoxies using the theoretical framework developed in Part I. It begins by asking, for example, if we really want every state or hamlet to determine for itself whether polychlorinated biphenyls create additional cancer risks greater than $10^{-6}$, and if so, at what cost these risks are worth worrying about. Sound environmental policies depend on good science, which, in turn, requires a level of investment in sophisticated technical analysis that many smaller jurisdictions are in no position to make. Given such capacity problems and the significant economies of scale in environmental analysis, Part III contends that across-the-board decentralization is unlikely to yield better results and may court disaster by weakening the scientific underpinnings of our policies.

Part III next makes clear that many environmental policy deficiencies arise from "structural failures" that occur when the scope of environmental effects does not match the jurisdiction of the regulating authority. Regulators tend to ignore extrajurisdictional harms (or benefits), which results in a skewed regulatory cost-benefit analysis. While some welfare loss arises because states are forced to pay for nationally mandated levels of environmental protection that their citizens would not have chosen, these "internalities" are relatively easy to fix without wholesale decentralization. Externalities - which occur when physical, economic, and psychological harms spill across jurisdictional lines pose a greater policy difficulty. As Part III points out, insofar as the central reason for environmental regulation is to mitigate the impact of market failures that emerge from uninternalized externalities, drawing more lines on the map only multiplies the potential for transboundary spillovers.

Part III also assesses the applicability of regulatory competition theory in the environmental realm and finds it limited. Many environmental problems exhibit threshold effects, time lags, and uncertainties that obscure the benefits of addressing them, especially in contrast with the visible and tangible gains of economic growth and jobs. While economists downplay fears of a race to the bottom, politicians cannot escape the image, in Ross Perot's memorable words, of a "giant sucking sound" as U.S. factories and jobs go down the drain to jurisdictions with more lax environmental standards and lower compliance costs. ${ }^{10}$ The slow and silent accumulation of greenhouse gases leading to cli-

MENTAl Protection (1996). Much of Revesz's article is more nuanced than this quotation suggests, but his opening challenge and conclusion are provocatively stark. Revesz himself seems to have begun to back away from this position. See Richard L. Revesz, Federalism and Interstate Externalities, 144 U. PA. L. REV. 2341 (1996).

10. Ross Perot, SAve Your Job, Save Our Country 41 (1993). 
matic change and agricultural declines thirty years from now on someone else's political watch is far less likely to be taken seriously by politicians obsessed with today's poll numbers and next year's elections. As Part III illustrates, the prospect of systematic miscalculations in the tradeoffs between environmental and economic goals makes the stateversus-state competitive dynamic likely to unleash welfare-reducing strategic behavior rather than efficiency improvements.

Finally, Part III focuses on whose views should "count" in the policy calculus. Modern Americans have a complex community identity with regard to environmental issues that makes this "choice of public" question nontrivial. Does the Grand Canyon, for example, belong only to Arizonans, or is it the birthright of all Americans? Devolution may neither improve the representativeness of environmental decisionmaking in any meaningful way nor reduce "public choice" distortions in the policymaking process. In making this observation, Part III ultimately recasts the second-generation arguments for decentralization as a set of policy rationales that sometimes will be salient within an overall argument for a multilevel regulatory structure designed to obtain the issuespecific advantages of both centralization and devolution.

The article concludes with a call for a presumption against presumption. It suggests that the challenge is to find the best fit possible between environmental problems and regulatory responses ${ }^{11}$ - not to pick a single level of government for all problems. The optimal environmental policy level and approach will depend on the problem at hand and what sorts of regulatory failures are most significant.

\section{Toward Optimal EnVIRONMENTAL Regulation}

Before delving into the question of what level of government is best positioned to address environmental issues, it is important to establish why environmental regulation ${ }^{12}$ is needed at all, what problems it seeks to correct, and how governmental intervention designed to improve social welfare might fall short. With a clear picture of optimal environmental regulation in mind and a firm understanding of how policy

11. See Steven Breyer, Regulation and Its Reform (1982) (making a similar argument that social goals and regulating strategies must be aligned).

12. My use of the term "regulation" should not be read to imply any preference for "regulations" per se (particularly not "command and control" technology mandates) as the means by which environmental goals are achieved. Indeed, in many cases, market mechanisms, such as pollution charges or emissions allowance trading mechanisms, will be superior to any traditional system of regulation. As used in this article, the terms "regulations" or "regulatory" thus should be read loosely to apply to all environmental policy strategies and instruments. 
failures arise, we then can assess the relative merits of decentralized and centralized regulatory structures.

\section{A. Starting Points}

Harms to the environment represent a diverse set of physical, biological, and chemical threats to human health or to the health of ecosystems on which we depend for sustenance or about which we care because of some other sociological, historical, or aesthetic reason. In short, such harms pose a threat to social welfare. ${ }^{13}$ This is not merely because environmental quality is an element of well-being, but also because environmental resources - air, water, and land - are inputs in all processes of production, if only as a place to dispose of waste. As a result, if social welfare is to be maximized by allocating resources with optimal efficiency, environmental resources must be valued properly in light of full social marginal costs. ${ }^{14}$

As externalities, environmental harms represent a threat not only to allocative efficiency and social welfare maximization, but also to the security of property. While not every spillover intrudes on the spillee's enjoyment of his land, those that do raise an issue of property rights. Whether or not one believes in a natural right to a clean environment, ${ }^{15}$ a longstanding norm of behavior, embodied in the common law of nuisance, protects property owners from unreasonable and uncompensated

13. While some ecological commentators argue that there is an independent moral obligation to protect the natural environment, see, e.g., ALDO LEOPOLD, A SAND COUNTY AlmanAC (1949), I do not rely on this ethical claim, but rather on a more traditional utilitarian view of environmental protection as an element of quality of life and therefore of social welfare. In this regard, Gifford Pinchot, one of the founders of the American conservation movement, offers a useful definition of the goal: "the foresighted utilization, preservation, and/or renewal of forests, waters, lands, and minerals, for the greatest good of the greatest number for the longest time." GifFORD PiNCHOT, BREAKING NeW GROUND 505 (Island Press 1987) (1947).

14. See, e.g., BAUMOL \& OATES, supra note 8; Maureen L. Cropper \& Wallace Oates, Environmental Economics: A Survey, 30 J. EcON. LITERATURE 675, 676 (1992). Value cannot, of course, be determined extrinsically from the political or regulatory process itself. See, e.g., MARK SAGOFF, THE Economy OF THE EARTH (1988); Howard Latin, Good Science, Bad Regulation, and Toxic Risk Assessment, 5 YALE J. ON REG. 89, 90 (1988). Without gainsaying the significance of the political dimension of the environmental policymaking process, I believe that disputes over the inherent value of resources explain only a small fraction of the nonoptimal environmental policies in place. As discussed below, other failures in the regulatory process represent a far bigger problem.

15. See William H. Rodgers, Jr., Bringing People Back: Toward a Comprehensive Theory of Takings in Natural Resources Law, 10 ECOLOGY L.Q. 205 (1982); see also Joseph SaX, Mountains Without HandRails: Reflections ON THE NaTIONAL PARKS (1980). 
spillovers. ${ }^{16}$ Our sense of justice and fairness thus is offended when pollution harms go uncompensated or uncontrolled. ${ }^{17}$

More fundamentally, efficiency cannot be discussed without establishing the boundaries of property rights, which in turn requires normative assumptions about what constitutes an environmental harm or an externality. ${ }^{18}$ Does $A$ have a right to use his land in a way that affects $B$ ? We generally answer this question by reference to the "reasonableness" of $A$ 's activities - a definition drawn from the common law of nuisance and derived from community standards of normal behavior and land use. ${ }^{19}$

This endpoint, however, is not entirely satisfactory. First, although community standards may evolve, they often lag behind knowledge about harms, especially in the environmental realm, where scientific understanding is constantly improving. ${ }^{20}$ Second, if an environmental harm

16. See RESTATEMENT (SECOND) OF TORTS $\$ \S 821-22$ (1978). For a historical discussion of the importance of the security of property, see Carol M. Rose, A Dozen Propositions on Private Property, Public Rights, and the New Takings Legislation, 53 WASH. \& LeE L. Rev. 265 (1996).

17. See Frank I. Michelman, Property, Utility and Fairness: Comments on the Ethical Foundations of "Just Compensation" Law, 80 HARv. L. REV. 1165, 1218-24 (1967); see also Robert C. Ellickson, Bringing Culture and Human Frailty to Rational Actors: A Critique of Classical Law and Economics, 65 CHI.-KENT L. REv. 23 (1989) (suggesting that the importance of "vested" rights is often underestimated in law and economics analysis). One can argue that utility depends, in part, on the fulfillment of public expectations that include preserving the sanctity of property. In this case, a good environmental regime protects property rights as a dimension of social welfare. Alternatively, protecting property rights may be seen as an absolute good and therefore as a limitation on the pursuit of welfare maximization. See JEAN JACQUES RousSEAU, DisCOURSE ON THE ORIGIN OF INEQUality 44 (Donald A. Cress trans., Hackett Publishing Co. 1992) (1754) ("The first person who, having enclosed a plot of land, took it into his head to say this is mine . . . was the true founder of civil society."); ADAM SMTTH, LeCTURES ON JURISPRUDENCE, REPORT OF 1762-63 (R.L. Meek et al. eds., 1979); see also Carol M. Rose, Property as the Keystone Right?, 71 NOTRE DAME L. REV. 329 (1996). In either case, the virtue of a regulatory regime depends in part on its success in protecting property rights.

18. See Stephen Cheung, The Myth of Social Cost, CATo PAPER \#16, Cato Institute (1980); Guido Calabresi, The Pointlessness of Pareto: Carrying Coase Further, 100 YAle L.J. 1211 (1991); Ronald H. Coase, The Problem of Social Cost, 22 CHEMTECH 1 (1992) (discussing the normative underpinnings of externalities).

19. See Robert C. Ellickson, Alternatives to Zoning: Covenants, Nuisance Rules and Fines as Land Use Controls, U. CHI. L. REv. 681, 729-31 (1972) [hereinafter Ellickson, Alternatives to Zoning]; Robert C. Ellickson, Takings Legislation: A Comment, 20 HARv. J.L. \& PUb. POlY. (forthcoming 1996); see also William A. FisChel, Regulatory Takings: LAw, Economics AND Politics 351 (1995); Donald Whitman, First Come, First Served: An Economic Analysis of "Coming to the Nuisance," 9 J. LEG. STUD. 557 (1980).

20. At one time, for example, lead was not known to be harmful, and normal behavior included allowing lead smelters to operate without pollution controls. Once the harmfulness of lead emissions was established, so too I believe was the existence of an 
spans more than one community, reliance on communal standards of normal behavior may be inadequate, as there may be no agreement on such standards between communities. Finally, the harm from environmental insults often rises nonlinearly because of threshold effects. If the harm from the one thousandth emitter is greater than that from the first, economic efficiency - marginal cost pricing - demands that the later emissions increments be priced higher than the earlier ones. ${ }^{21}$ Thus, in addition to grounding property rights on community norms, which might be summed up as "do unto others as you would have them do unto you," the boundaries of reasonable activity must also be - and in practice are - defined by a scientifically derived "do no harm" principle. $^{22}$

\section{B. The Need for Regulation}

If property rights over environmental resources were clearly defined and enforced ${ }^{23}$ and the transaction costs of negotiating their purchase and sale were negligible, then a free market for environmental resources would produce environmental-harm-internalizing, welfaremaximizing, ${ }^{24}$ fair outcomes. ${ }^{25}$ There would be no environmental problems to be solved, and hence no need for regulation. Private party

infringement of the property rights of those facing spillovers from smelters, regardless of the fact that it might have taken some number of years for community standards to catch up with the evolving epidemiological understanding of lead. Of course, "elite" recognition of such harms is likely to lead "mass" perception of a new externality, creating policy stress such as currently exists with regard to wetlands and endangered species protection. See, e.g., Bettina Soderbaum, Revaluing Wetlands, OECD OBSERVER, Feb.-Mar. 1996, at 47-50 (noting that half of the available wetlands worldwide have been destroyed because of the misconception that wetlands are useless).

21. Marginal cost pricing may raise equity issues insofar as some people will perceive unfairness to the extent that later polluters will be asked to pay more than earlier ones for the same measure of emissions.

22. Harm here is defined as anything more than de minimis welfare loss. There are many examples in which property rights are delimited not by prevailing community standards but by the identification of harm. See, e.g., Penn Central Terminal v. City of New York, 438 U.S. 104 (1978) (holding that no one has a right to use their property in a manner that harms others). A Calabresian principle of lodging rights in ways that maximize welfare also would argue for a definition of externalities derived from measurable harm rather than from community behavioral norms. See GuIDo CAlabresI, THE Cost OF ACCIDENTS: A LegAL AND ECONOMIC ANALYSIS (1970).

23. See Harold Demsetz, Toward a Theory of Property Rights, 57 AM. ECoN. REV. 347 (1967).

24. See R.H. Coase, The Problem of Social Cost, 3 J.L. \& Econ. 1 (1960) (observing that efficiency can be achieved regardless of who holds the property rights).

25 . "Fair" in this context refers only to the issue of respecting property rights. A broader fairness issue - whether the initial endowment of rights is equitable - remains open and is not addressed in this article. 
exchanges and a simple framework of tort and contract rules to ensure that established rights could be vindicated would define a sufficient environmental protection regime.

Because of the nature of environmental problems, however, the relevant property rights are often poorly defined, ${ }^{26}$ and the transaction costs of negotiating their sale and purchase are frequently high. ${ }^{27}$ Both circumstances entail market failures and a concomitant need for environmental regulation. The specific souices of such failures are enumerated below.

\section{Technical Transaction Costs}

Some costs associated with addressing environmental harms are the product of technical uncertainty. Even when property rights to environmental resources are clearly defined, the value of these resources is not easily reduced to monetary figures that can be compared and exchanged. A person holding a property right against pollution may not know - or be able to know - the terms on which he rationally would trade all or some of that entitlement. Not only are infringements of property rights hard to detect given the invisibility of many pollutants, but individuals also cannot easily judge what risks of public health or ecological damage are posed by pollution. Told that a particular exposure creates $10^{-5}$ risk of death, people do not know what value to place on the harm they are suffering and thus how much compensation to seek. $^{28}$

26. See Carol M. Rose, Rethinking Environmental Controls: Management Strategies for Common Resources, 1991 DUKE L.J. 1; see also RICHARD A. POSNER, AN ECONOMic ANAlysis of LAw (4th ed. 1992); Peter L. Kahn, The Politics of Unregulation: Public Choice and Limits on Government, 75 CORNELL L. REV. 280 (1990). For more on the reasons why one might want property rules in some cases and liability rules in others, see Guido Calabresi \& A. Douglas Melamed, Property Rules, Liability Rules and Inalienability: One View of the Cathedral, 85 HARV. L. REV. 1089 (1972); Ellickson, Alternatives to Zoning, supra note 19; Frank I. Michelman, Pollution as a Tort: A Non-Accidental Perspective on Calabresi's Costs, 80 YALE L.J. 647, 667-83 (1971); A. Mitchell Polinsky, Controlling Externalities and Protecting Entitlements: Property Right, Liability Rule, and Tax-Subsidy Approaches, 8 J. LEGAL STUD. 1 (1979); Susan Rose-Ackerman, Inalienability and the Theory of Property Rights, 85 COLUM. L. Rev. 931 (1985).

27. See, e.g., Calabresi, supra note 18, at 1215; Robert L. Rabin, Environmental Liability and the Tort System, 24 Hous. L. REV. 27 (1987) (discussing regulation via tort system); Stewart, Pyramids, supra note 7, at 1212.

28. See Mark Landy et al., The Environmental Protection Agency: ASKING THE WRONG QUESTIONS 283-88 (1990) (arguing that environmental risks are very imperfectly understood); Rabin, supra note 27 (discussing problems of identification, boundaries, and sources of environmental pollution); Palma J. Strand, Note, The Inapplicability of Traditional Tort Analysis to Environmental Risks: The Example of 
Resolving such uncertainties is complicated by the diversity of pollution problems and the risk of "information overload" that they create. Particulates in the air, organic wastes in water, and most solid wastes disposed of on land can be seen as "flow" pollution that degrades relatively rapidly and for which the environment has some assimilative or absorptive capacity. Pollutants of this type pose a threat only when they are concentrated spatially and temporally. "Stock" pollutants, on the other hand, such as some radioactive materials, heavy metals, certain toxic chemicals, and other bioaccumulative substances, degrade much more slowly. Because the environment has little or no absorptive capacity for these substances, they have an additive or cumulative effect that makes connecting particular proportions of observed harms to specific sources of pollution difficult. In addition, assumptions about how much harm certain environmental problems cause are constantly changing as scientists uncover new harms, new pathways of exposure to old harms, new connections between emissions and public health or ecological injuries, and new ways to reduce the risks from environmental threats. Moreover, the ability of science to measure ever smaller amounts of pollution adds to the fluidity of environmental knowledge.

On top of this causal complexity, individuals face the additional difficulty of putting an appropriate value on the harms caused by pollution. While contamination at low levels may not be harmful, many pollutants exhibit threshold effects such that initial increments of emissions cause no harm while exposure beyond a certain point causes damage. ${ }^{29}$ Furthermore, as epidemiologists, toxicologists, and ecologists recognize, for every pollutant there exists a unique dose-response function that results in a distinct pattern of deleterious effects on human health or ecological resources.

Deriving cumulative and net harms from pollutants heightens the technical complexity of environmental policymaking. Many pollutants interact with each other and with other substances. For example, radon, a naturally occurring radioactive gas found in the basements of millions

Toxic Waste Pollution Victim Compensation, 35 STAN. L. REv. 575 (1983); William D. Nordhaus, Locational Competition and the Environment: Should Countries Harmonize Their Environmental Policies 5-8 (1994) (discussion paper No. 1079, Cowles Foundation for Research and Economics, Yale University) (discussing the heterogeneity of pollution with respect to time, space, cost, and economic impact).

29. Pezzey usefully distinguishes between "effluent" and "pollution," the former reflecting emissions up to the threshold of harm, the latter describing emissions beyond the assimilative capacity of an ecosystem. See John Pezzey, Market Mechanisms of Pollution Control: "Polluter Pays," Economic and Practical Aspects, in SustaINABle EnVironmental Management: PRINCIPLes and Practice 190 (R. Kerry Turner ed., 1988). 
of homes in America, produces much more serious lung-cancer risks for smokers than it does for nonsmokers. Similarly, some pollutants cause multiple harms. For example, chlorofluorocarbons (CFCs) not only cause depletion of the ozone layer but are also greenhouse gases. A pollutant may also evince both harmful and helpful effects simultaneously. Sulfur dioxide, for instance, causes potentially serious respiratory harm as a ground-level air pollutant but appears to cool the upper atmosphere, thus counteracting the risk of global warming.

Technical transaction costs are driven up further by the wide range of exposure routes through which environmental harms arise. Environmental scientists devote a great deal of effort to tracing the "fate and transport" of chemicals. Some pollutants, such as sulphur dioxide, spread relatively uniformly through the environment into which they are injected. Other forms of pollution, such as toxic substances disposed of on land, tend to concentrate geographically and mix nonuniformly with the surrounding environment.

Progress in addressing the most obvious sources of pollution (the emissions from major factory smokestacks and effluent pipes) means that our residual pollution problems are more diffuse, less visible, and more technically challenging. As the emissions from thousands of smaller sources (such as bakeries, dry cleaners, and garages), "nonpoint" sources (such as runoff from farms or lawns), and the cumulative effects of millions of individual environmental impacts (such as auto emissions) become more central, the prospect of individual property holders being able to vindicate their rights through a nonregulatory, contract-tort regime becomes less and less likely.

Regulation, of course, does not eliminate these various technical uncertainties, ${ }^{30}$ but it does allow for broad-based scientific activities that benefit from economies of scale and for collectively derived best approximations about environmental harms. Regulation thereby dramatically reduces technical transaction costs.

30. There is, of course, a debate over how objective science, and thus technical analysis, can be. Huber argues a strong positivist line. See Peter Huber, Galileo's REVENGE: JUNK SCIENCE IN THE COURTROOM 221 (1991). Jasanoff, in contrast, rejects the idea that science represents an objective reality waiting to be uncovered. See Sheila Jasanoff, The FifTh Branch: Science Advisors as Policymakers 12-14 (1990). Similarly, Latin suggests that we drop the pretense that regulatory decisions have a purely scientific or rational underpinning and acknowledge that they are also matters of political choice. See Howard Latin, Good Science, Bad Regulation and Toxic Risk Assessment, 5 YAlE J. ON REg. 89, 90 (1988); see also Peter A. Schuck, Multi-Culturalism Redux: Science, Law, and Politics, 11 YAle L. \& POLY. ReV. 1, 1516 (1993) (arguing that "the contingent, socially constructed, and validated, resourceconstrained character of scientific paradigms and propositions ... is an important antidote to the more transcendent, universal pretensions of certain conceptions of science"). 


\section{Administrative and Strategic Transaction Costs}

Assume now that in addition to fully defined property rights over environmental resources, technical transaction costs are zero. The fate, transport, and ecological and public health effects of every pollutant are known to all affected parties. A second set of transaction costs that derive from the dynamics of bargaining becomes evident. People do not arrive at terms readily in complicated multiparty exchanges, even if a range of universally acceptable outcomes exists. Holding out, free riding, and other strategic actions may preclude an efficient outcome. ${ }^{31}$ Regulation reduces these strategic transaction costs by selecting and enforcing preferred outcomes directly. ${ }^{32}$ In addition, regulation reduces or eliminates the administrative costs of negotiating an exchange of rights or suing to vindicate rights with respect to private parties. ${ }^{33}$

\section{Legal Uncertainty or Poorly Defined Property Rights}

Drop the initial assumption of clearly established individual property rights over environmental resources, and a further argument for regulation emerges. Not only are the transaction costs of delineating property rights substantial - indeed, prohibitive in some cases - but the lack of established rights can also lead to direct system failures as non-rights-holders take advantage of the confusion to do as they please.

31. See Avinash Dixit \& Barry Nalebuff, Thinking Strategically (1991); HowARD RAIFFA, ThE ART AND SCIENCE OF Negotiation (1982); see also Richard A. Epstein, Holdouts, Externalities, and the Single Owner: One More Salute to Ronald Coase, 36 J.L. \& ECON. 553, 582-84 (1993).

32. See Thomas W. Merrill, Trespass, Nuisance, and the Costs of Determining Property Rights, 14 J. LEGAL STUD. 13, 24-25 (1985) (arguing that courts apply judgmental entitlement-determination rules in nuisance cases, in which the barriers to private transactions would be relatively high, while they apply mechanical entitlement-determination rules that facilitate private bargaining in trespass cases, in which the barriers are relatively low); see also SENATE COMM. ON GovernMENT AFFAIRS, STUdY OF Federal Regulation, S. Doc. No. 95-91, at 7 (1978); Richard B. Stewart \& JAMES E. KRIER, ENVIRONMENTAL LAW AND PoliCy 198-324 (2d ed. 1978) (discussing the failure of private litigation in dealing with environmental problems); George J. Stigler, The Economists' Traditional Theory of the Economic Function of the State, in The Citizen ANd The STate 103, 110 (1975); Robert Ellickson, Public Property Rights: A Government's Rights and Duties When Its Landowners Come Into Conflict With Outsiders, 52 S. CAL. L. Rev. 1627, 1632-43 (1979); Richard B. Stewart \& Cass R. Sunstein, Public Programs and Private Rights, 95 HARV. L. REv. 1193, 1236-37 (1982).

33. If the cost of bringing a legal action exceeds the likely recovery for an environmental injury, the existence of the property right may be clear, but that right will not be vindicable due to the transaction costs. Many environmental injuries inflict small harms on many people such that individually no one has enough of a stake in bringing the harm-causer to justice to justify the legal costs involved. 
Without clear rules, a Hobbesian state of nature takes hold. ${ }^{34}$ Polluters pollute with impunity, and the strong seize commonly held resources without restraint. ${ }^{35}$ Government failure - or, more precisely, the absence of a functioning legal regime - compounds the market failure.

a. The Problem of the Commons. Some natural resources, such as the atmosphere, are inherently "public goods" and simply not susceptible to division into private property holdings. ${ }^{36}$ Other environmental resources, such as national parks, while not intrinsically public, have a long history of being collectively "owned." 37 When shared resources become scarce, a familiar dynamic - the tragedy of the commons takes hold. ${ }^{38}$ Because, by definition, individuals do not pay the full marginal cost of the public goods that they acquire, each person has an incentive to overconsume. Without clear property rights and allocation rules, the resulting overconsumption leaves the participants worse off then they would have been had they agreed on an appropriate resource division among themselves. ${ }^{39}$ Powerful individuals or groups, moreover, may seize disproportionate shares of limited public goods and enrich

34. See Thomas HobBes, Leviathan (1885). Hobbes argues generally that a centralized government (the Leviathan) is required to quell the decentralized "state of nature," which inevitably will lead to the destruction of man if not stopped.

35 . Theoretically, the state of nature favors the strong, not necessarily polluters. Thus, one could envision circumstances whereby, in the absence of clear property rights, lower-than-efficient pollution levels would result, enforced by a powerful state with low-pollution preferences. For example, the United States might force Mexico to close factories along the border although the harm suffered in the United States was very minor (for instance, unsightly plumes of steam). In practice, however, the unclearrights scenario almost always favors polluters or consumers of public goods. This result follows because, in the absence of property rights to which deference must be given, other legal norms apply - notably, the belief that "possession is nine-tenths of the law" and that exercising force in the absence of a clear claim of right is unseemly if not immoral.

36. A property rights regime can be established for emissions into the atmosphere. See, for example, the sulfur dioxide (acid rain) allowance trading system set up under the Clean Air Act of 1990, 42 U.S.C. § 7651 (1995).

37. Many Americans consider their ownership interests in such resources to be part of the national patrimony, making privatization problematic and management as a public resource preferable. See, e.g., Christopher K. Leman \& Robert H. Nelson, The Rise of Managerial Federalism: An Assessment of Benefits and Costs, 12 ENvTL. L. 981, 1001-02 (1982); Carol M. Rose, The Comedy of the Commons: Custom, Commerce, and Inherently Public Property, 53 U. CHI. L. REV. 711 (1986). Of course, not all traditionally publicly held resources are created equal. It may well be that the federal government need not retain all of the land it currently holds.

38. Although the understanding of this problem as the tragedy of the commons is relatively new, the problem of scarcity and its effect on property rights can be traced to Locke and Blackstone. See Rose, supra note 16, at 267-70.

39. For the classic version of this problem, see Garrett Hardin, The Tragedy of the Commons, 162 SCIENCE 1243, 1244-45 (1968); see also Gordon Tullock, Federalism: Problems of Scale, 6 PUB. CHOICE 19, 25-28 (1969). 
themselves unfairly at the expense of the rights others hold to a share of the commons. The need for collective action to respond to this "prisoners' dilemma" dynamic is now well understood and represents a strong argument for regulation..$^{40}$

b. The "Reasonableness" of Externalities. Even if all property is privately owned, disputes over environmental harms will persist. As noted above, when $A$ spills something onto $B$ 's property, there will often be some uncertainty over whether $A$ has a right to emit or $B$ has a right not to be polluted. Although historically the touchstone has been the reasonableness of the intrusion, ${ }^{41}$ property rights often will be in dispute because there is no bright-line definition of what is reasonable. Moreover, reasonable levels of pollution may evolve over time as new harms emerge, conditions become more crowded (and once-reasonable emissions intermingle with other emissions, cumulatively becoming unreasonable), and science advances our knowledge of harms such that activities that once seemed relatively innocuous are deemed harmful and unreasonable. Thus, even in a seemingly simple case, disputes as to who holds rights may arise.

As in the case of the uncontrolled commons, the absence of clear property rights leads to a Hobbesian Rule of the Strong. The results likely will be unsatisfactory because the default rule (polluters seize the property rights) violates our underlying norm against uncompensated spillovers. Of course, the outcome in this case need not be inefficient if Coasian bargaining results in the pollutee paying the polluter to reduce emissions to an optimal level. ${ }^{42}$ But regulation may produce a superior

40. See Mancur Olson, The logic of Collective Action: Public GOODS AND THE THEORY OF GROUPS (1965); see also JOHN STUART MILL, ON LIBERTY (Viking Penguin 1982) (1859) (observing that no function of government is less optional than the regulation of forests, waters, etc.). But see Demsetz, supra note 23 (suggesting that the clarification of private property rights will help to address the collective action problem).

41. Restatement (SECOND) OF TORTS $\S \S 821-22$ (1978). This legal principle - effectively placing property rights with potential pollution victims - represents a powerful moral intuition that has had status as a behavioral norm for centuries. See Rose, supra note 16.

42. A real-world example of this phenomenon can be seen in the environmental relationship between China and Japan. China's coal burning results in considerable sulfur dioxide emissions that have measurable (multibillion dollar) impacts on Japan. Nothing prevents Japan from asserting a property right not to be disturbed by this transboundary harm. See Declaration on the Human Environment: Report of the United Nations Conference on the Human Environment, U.N. Conference on the Human Environment, at 5, U.N. Doc. A/CONF.48/14/Rev.1 (1972), reprinted in 11 ILM 1416 (1972); Rio Declaration on Environment and Development, U.N. Conference on Environment and Development, at 5, U.N. Doc. A/CONF.151/5 (1992), reprinted in $31 \mathrm{ILM} \mathrm{874,} 876$ (1992). However, given that there is no mechanism for vindicating these property rights 
outcome by establishing the boundaries of permitted behavior and thereby ensuring that the results are fair as well as efficient.

The following chart summarizes the potential shortcomings of a common law approach to controlling environmental harms. If property rights are not defined or transactions costs are not low, we end up with economic inefficiency and welfare loss, or a violation of basic property rights, or both. In either case, governmental intervention offers the promise of improved results. ${ }^{43}$

\section{Chart A: Property Rights and Transaction Costs}

\begin{tabular}{|c|c|c|}
\hline & Clear Property Rights & Property Rights not Clear \\
\hline $\begin{array}{c}\text { No or Low } \\
\text { Transaction } \\
\text { Costs }\end{array}$ & $\begin{array}{l}\text { - rights respected } \\
\text { - bargaining produces } \\
\text { efficient results } \\
\text { - no need for regulation }\end{array}$ & $\begin{array}{l}\text { - unlear rights lead to default rule } \\
\text { (polluters seize property rights) } \\
\text { - Coasian bargaining may nevertheless } \\
\text { produce efficient results } \\
\text { - government intervention needed to } \\
\text { ensure fair results }\end{array}$ \\
\hline $\begin{array}{c}\text { High } \\
\text { Transaction } \\
\text { Costs }\end{array}$ & $\begin{array}{l}\text { - rights may not be } \\
\text { vindicable } \\
\text { - transaction costs make } \\
\text { bargaining to efficient } \\
\text { results unlikely } \\
\text { - regulation may lead to more } \\
\text { efficient and fair results }\end{array}$ & $\begin{array}{l}\text { - unclear rights leads to default rule } \\
\text { (polluters seize property rights) } \\
\text { - bargaining to efficient results } \\
\text { unlikely } \\
\text { - need regulation to achieve efficient } \\
\text { and fair results }\end{array}$ \\
\hline
\end{tabular}

\section{A Typology of Environmental Regulatory Failures}

While regulatory approaches to environmental problems can improve social welfare, the specific regulatory strategies undertaken often fall short of the optimum. To maximize utility, environmental regulations must be pushed to the point - and only to the point - where the benefits of an additional dollar of pollution prevention or control equal

in the international realm, any such assertion by Japan is essentially useless. As a result, Japan's rights effectively do not exist, and China by default claims the right to pollute. Japan therefore is forced to subsidize Chinese sulfur dioxide abatement through a "Green Aid" program aimed at getting the Chinese to install scrubbers on their power plants. See Peter Evans, Japan's Green Aid, ChINA Bus. Rev., July-Aug. 1994, at 3943.

43. Within a single jurisdiction, property rights may be relatively clear and vindicable so that transaction costs become the dominant variable determining the optimal response to environmental harms. When, however, we move from an island jurisdiction to a multiple-jurisdiction world, we raise the specter of property-rights uncertainties and further strain the possibility that a decentralized tort- and contract-based approach to environmental harms will be adequate. 
the costs of the activities undertaken. ${ }^{44}$ Viewed another way, "least social cost" environmental regulation should minimize the sum of pollution abatement expenditures (including regulatory costs) and losses inflicted by unabated pollution harms. ${ }^{45}$ With this objective in mind, three broad categories of regulatory failure and welfare loss can be discerned: technical deficiencies, structural mismatches, and public choice problems.

\section{Technical Deficiencies in Regulation}

Technical welfare losses arise for two distinct reasons. First, the information on which regulatory decisions rest can be incomplete or inaccurate. How much acid-rain-causing $\mathrm{SO}_{2}$ has been emitted may be measured incorrectly or miscalculated. Similarly, the public health or ecological risks arising from a particular environmental harm may be misunderstood or miscalculated. What level of exposure to sulfates causes respiratory disease? How much acid rain will cause trees to die? Mistakes in answering such questions represent a weakness in technical capacity. In such cases, more accurate data, scientific analysis, risk assessment, or cost-benefit calculations would improve the technical content of regulation and thus would result in more accurate environmental resource pricing. ${ }^{46}$

A second type of technical welfare loss consists of the administrative costs of regulation. This set of technical costs has two conceptually distinct components. First, for any given level of technical capacity, regulatory systems may have differing administrative costs. For instance, federal bureaucrats and state bureaucrats may both be able to

44. This utilitarian goal, as discussed earlier, should be pursued subject to the constraint that property rights are respected. See supra text accompanying notes 15-17.

45. For a thorough review of the economics of environmental regulation, see BAUMOL \& OATES, supra note 8. Least social cost analysis implies that benefits and costs can be quantified at least roughly and then compared. As discussed supra note 30, some commentators argue that science is so uncertain and subjective and that individuals and communities vary so widely in their risk valuations that all environmental policy decisions are political and thus that cost-benefit analyses are of limited value. Yet some aspects of policy analysis are objective - for example, measurements of pollution; this means that better technical analysis will reduce the scope of policy uncertainty and thus the sphere in which political judgment is required.

46. It is important to realize that this category of regulatory failure is broad enough to encapsulate various "political" or quasi-normative incapacities, particularly with regard to how much value to place on policy interventions. For instance, a community may believe that controlling a certain risk is worth on average $\$ 2$ million per life saved. A regulator, even trying in good faith to discern the community's values, may not have the technical capacity to arrive at the $\$ 2$ million figure. Some "technical" failures - particularly in cost-benefit analysis - will thus be hard to distinguish from "public choice" or political failures. See infra text accompanying notes 79-89. 
determine what level of benzene in the air is safe to breathe and to do so in the same amount of time, but federal bureaucrats have higher wages, making the federal system more costly. Alternatively, the federal officials may work longer or faster, thus producing more regulatory output per dollar invested, making the federal system more cost-effective from an administrative point of view. Second, a tradeoff exists between improved technical content and the costs associated with running a regulatory system that achieves greater precision. For example, although equating the marginal cost and benefit of pollution control for every person in the country on an individual basis - such as by specifying individualized benzene standards for the air around each household would minimize welfare losses associated with divergences between policy outcomes and individual preferences, it would come at a vast administrative cost. Thus, additional welfare losses arise from failures to regulate with optimal specificity. ${ }^{47}$

Although technical failure can occur at any stage of the regulatory process, ${ }^{48}$ the effects of "early" mistakes may be compounded and hence more serious. Some errors will result in total regulatory failure, while other mistakes will affect only the level of response. ${ }^{49}$ The biggest errors, which occur when causal connections are misunderstood or when risks are misjudged by multiple orders of magnitude, are more likely to arise from the "technical" end of the regulatory process (such as faulty data collection and analysis) than from "political-technical"

47. There is a significant body of literature that addresses the optimal specificity of regulations and the tradeoffs between uniform standards and regulatory diversity. See, e.g., Richard A. Posner, AN ECONOMic ANAlysis of LAw 367-70 (4th ed. 1992) (arguing that the key question is whether the benefits of particularization outweigh the costs); Isaac Ehrlich \& Richard Posner, An Economic Analysis of Rulemaking, 3 J. LEGAL STUD. 257, 262 (1974); see also Colin Diver, The Optimal Precision of Administrative Rules, 93 YALE L.J. 65 (1983).

48. Technical failure, as understood here, can occur simultaneously within one, some, or all of these elements:

1. Problem identification

2. Data collection

3. Fate and transport analysis

4. Epidemiological and ecological studies

5. Risk assessment

6. Policy design and alternatives development

7. Cost-benefit analysis

8. Implementation and enforcement

9. Evaluation

49. For example, mistaken fate-transport or epidemiological analyses can lead regulators to target the wrong cause of harm, whereas using a \$20 million figure per value of life saved versus the actual community value of $\$ 2$ million simply results in a standard being set ten times too high. 
activities (such as using the wrong "values" in a cost-benefit calculation). ${ }^{50}$

\section{Structural Mismatches}

Environmental regimes also risk structural failure unless the regulating entity adds up all the costs and benefits of a proposed policy. In particular, if some of the cost-bearers or beneficiaries of an environmental action fall outside the borders of the regulating jurisdiction, their interests in the policy outcome may not be taken into account. ${ }^{51}$ Whenever the scope of an environmental harm does not match the regulator's jurisdiction, the cost-benefit calculus will be skewed and either too little or too much environmental protection will be provided. Chart B shows how structural mismatches can be broken down into four basic forms: (1) negative externalities; (2) positive externalities; (3) internalities; and (4) potential takings.

Negative externalities result when the jurisdiction of the regulating entity is too small and harms accrue beyond the boundaries of the regulator. When such a mismatch occurs, and external harms are disregarded, the cost-benefit calculation undertaken by the regulator will understate the costs of the emissions, and underregulation (too much pollution) results. Transboundary pollution spillovers represent the classic negative externality. Positive externalities arise when an activity, such as protecting a tropical forest, produces benefits that accrue beyond the regulating jurisdiction..$^{52}$ In this case, because the regulator ignores the potential welfare gains of the extrajurisdictional beneficiaries, too little of the public good is provided.

50. Specifically, although disputes over the value of a human life saved might range across an order of magnitude and although some value clashes might even rise to two orders of magnitude, scientific estimates (for example, the likelihood that a certain chemical exposure will cause harm) often vary by many orders of magnitude and may even result in "directional" errors.

51. See, e.g., John B. Braden, The Economics of Environmental Policy-Making in a Multi-Level Government Structure, in RECENT ECONOMIC AND LEGAL DEVELOPMENTS IN European Environmental Policy 49-74 (Filip Abraham et al. eds., 1995).

52. Forests, for example, provide carbon sequestration benefits that reduce the risk of climate change across the entire planet. In addition, many forests support biological diversity, which benefits all humankind. For a discussion of various kinds of positive externalities in the environmental context, see DANIEL C. ESTY, GREENING THE GATT: TRADE, ENVIRONMENT AND THE FUTURE 125-26 (1994). 
Chart B: Structural Mismatches

I. Negative Externality

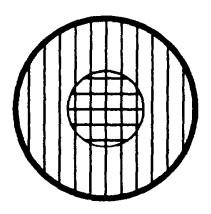

II. Positive Externality

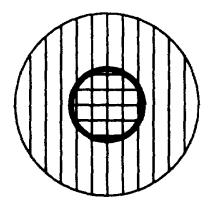

III. Internality
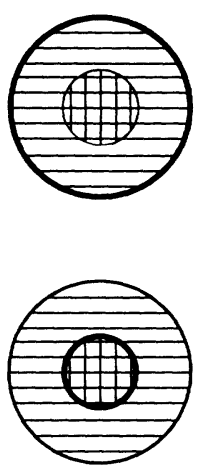

IV. Potential Taking

$-\quad=$ Scope of environmental effect

$-\quad=$ Scope of regulating effect

\|\|\|\|$=$ Cost Bearers
$\underline{\equiv}=$ Beneficiaries 
When the jurisdiction is broader than the scope of the public good in question, internalities may arise because majoritarian voting denies an optimal level of public goods to a subjurisdiction. ${ }^{53}$ Such a mismatch arises, for example, if a neighborhood wants to build a park and is willing to pay for it, but is voted down by the other citizens of the town who fear higher taxes. ${ }^{54}$ Similarly, internalities arise if a subjurisdiction would opt out of acquiring a particular public good but is forced to pay for an unwanted level of environmental protection by a decision made at a higher level of government. An example of this type of structural mismatch would be a requirement that local water suppliers install nationally specified drinking-water pollution controls. ${ }^{55}$

The fourth type of mismatch arises when the regulating entity provides benefits broadly but concentrates costs unfairly on a narrow group. Assuming that the cost-bearers have done nothing to justify a disproportionate burden, their property rights may be infringed. ${ }^{56}$ Indeed, the problem of a potential taking is not a structural mismatch but rather a question of protecting property rights against majoritarian and utilitarian overreaching.

Externalities and internalities could be dealt with by clarifying who holds the property rights if transaction costs were low and bargaining could be undertaken. If, however, transaction costs are high, then regu-

53. See Mancur Olson, Jr., Strategic Theory and Its Applications - The Principle of "Fiscal Equivalence": The Division of Responsibilities Among Different Levels of Government, 59 AM. ECON. REV. 479, 482 (1969) (observing that "internalities" exist when a public good reaches only a subset of the population in a jurisdiction). As Olson notes: "In a situation of this type and a democratic political system with voting by majority rule, the provision of a collective good for a local area will hurt more people than it helps, even if Pareto optimality would have required that the collective good be produced." Id.

54. My categories of regulatory failure obviously blur at the margins. For example, the defeated park could be seen as a case in which local preferences diverge from those of the broader jurisdiction. The situation could also be seen as a public choice problem because the welfare loss arises from a disjunction between the wishes of those in the subjurisdiction and the policy program imposed on them from a higher level. But of those I call this a structural mismatch and instead reserve the public choice rubric for cases in which the problem arises not as a result of a jurisdictional misalignment between the scope of a public good and the boundaries of the regulating entity, but rather because of distortions in the translation of the public's desires into policy within a properly defined jurisdiction.

55. See Safe Drinking Water Act, 42 U.S.C. § 300g-3 (1994).

56. Seizing a private property owner's land to create a public park would, for example, constitute a taking and require compensation under the Fifth Amendment to the Constitution. Who should be compensated and by how much is, of course, a matter of considerable controversy. See, e.g., FISCHEL, supra note 19; Frank Michelman, Property, Utility, and Fairness: Comments on the Ethical Foundations of "Just Compensation" Law, 80 HARV. L. REV. 1165 (1967); Rose, supra note 16. 
lation is necessary and welfare maximization requires that the jurisdiction of the regulating authority - or at least the scope of costs and benefits factored into the regulatory calculus - be coterminous with the extent of the harm to be prevented or the good to be provided. To achieve optimality, externalities require some form of centralization and internalities require some degree of decentralization.

In general, internalities will be easier to fix than externalities. Partial devolution (a tax just on the neighborhood that will benefit from the park) can make the scope of the costs and benefits match. Although inertia must be overcome, no one has to act against his own fundamental interests to achieve a solution. In contrast, internalizing externalities requires getting outsiders to cooperate. Insofar as those groups that are externalizing costs or receiving positive spillovers currently enjoy something for free, they have no incentive to pay. ${ }^{57}$ For example, fertilizer use by Massachusetts farmers greatly affects the quality of water in the Connecticut River. Connecticut, however, has had little success in getting the upstream farmers to change their behavior. Not only does Connecticut have no direct authority over the Massachusetts polluters, but the upstream farmers also balk at bearing the costs of control - in reduced yields or higher fertilizer-application costs - when they will receive little benefit. Similarly, although Americans seem quite willing to insist that Brazil protect its rainforests, they are much less excited about paying for the biodiversity, oxygen production, carbon sequestration, and other conservation benefits that they receive from Brazil.

The need for an overarching governmental response to externalities does not, of course, settle the question of what sort of regulatory regime should be put in place. One answer is a centralized regulatory system. But multijurisdictional spillovers also might be addressed by collaboration among decentralized governments. Whether a collaborative regime rather than a centralized one will be sufficient to address the collective action problem turns on a number of factors: (1) the existence of common environmental norms; (2) the direction of the spillovers in question; and (3) the ease with which property rights can be exchanged or vindicated. .8

At the outset, collaboration depends on the existence of common environmental norms that make determinations about the boundaries of

57. Unless, of course, the externalities go both ways, in which case today's winner may be tomorrow's loser. This changes the game to a prisoner's dilemma and provides sufficient reciprocity to support collective action solutions.

58. The problem of getting optimal interjurisdictional environmental policy through collaboration mirrors the difficulty of using a common law approach to address environmental harms in the first place. See supra text accompanying notes 23-43. 
property rights possible. Absent, for example, an agreed-upon standard of reasonableness in the nuisance context across the jurisdictions in question, there is no basis for deciding whether an externality exists. ${ }^{59}$ In the terminology of game theory, there is no zone of agreement among the parties.

The direction of the flow of harms will also affect the likelihood of achieving effective interjurisdictional cooperative policies. If spillovers go both ways, each party has an incentive to collaborate in the pursuit of collective-action solutions that establish a workable control regime. $A$ limits its emissions onto $B$ so $B$ will control its spillovers onto $A$. When, however, the flow of harms is substantially unidirectional, the problem takes on a zero-sum flavor that makes collaboration much more difficult. If the flow is always from $A$ to $B$, why should $A$ control its emissions? In such nonreciprocal cases, environmental norms clash with other norms in ways that may make collaboration more difficult. For example, if the pollution flows from the stronger to the weaker party, the tendency of the strong to advance its own self-interest may override its commitment to the control of transboundary environmental harms. ${ }^{60}$ The United States, for instance, long refused to acknowledge Canadian claims about acid rain. Of course, if the harm flows from the weaker party onto the stronger, the no-transboundary-pollution norm is more likely to hold because the power relationship reinforces the environmental rules. ${ }^{61}$

59. To see the importance of common norms, consider the difficulty of getting China and the United States to agree on a unified approach to the problem of climate change. In the negotiations, the United States might declare that transboundary emissions of greenhouse gases must be controlled or compensation paid. The United States might cite the longstanding common law of nuisance or the "no transboundary spillovers" norm embodied in Principle 2 of the Rio Declaration. The Chinese, however, will respond that the fundamental principle must be that poor nations should be allowed to do what they must to develop quickly. They might cite the law of necessity or the "right to develop" in the Rio Declaration in support for their norm.

60. The commitment to vague norms, such as not allowing transboundary pollution harms, may break down in confrontation with the demands of self-interest. Indeed, in the environmental realm, where norms are often weak or ambiguous, normative dissonance is a common problem. U.S. enthusiasm for the enforcement of a no-spillover rule in the international domain, for example, appears to have been tempered by the recognition that the United States is a major international net polluter. Interestingly, China's rapid economic rise and the accompanying increase in its transboundary emissions may soon put the shoe on the other foot for the United States and convert Americans into advocates for real enforcement of the no-transboundary-spillovers norm.

61. The unidirectional flow may result in "too much" control because there is no prospect of the stronger party being saddled with excess costs when the circumstances are reversed. Thus, for instance, Mexico agreed to install scrubbers on a number of its power-generating stations along the U.S. border even though the plants complied fully 
Finally, the possibility of interjurisdictional nonregulatory collaboration depends on the presence of mechanisms both for the exchange of property rights and for their enforcement at relatively low cost. In particular, common tort and contract rules must exist or courts must be willing to execute judgments from other jurisdictions. Obviously, the prospects of establishing this sort of legal collaboration depend greatly on the relationship among the jurisdictions at issue. When the entities in question are U.S. states, strong links make interjurisdictional coordination conceivable. When the jurisdictions cross international lines, however, the transaction costs of case-by-case collaboration are likely to be much higher and the probability of making such a regime work correspondingly lower. Although there might be a potential zone of agreement between or among the parties, the cost of finding it may be prohibitive.

Regulation, of course, does not eliminate these difficulties. But the shift to a more centralized policy regime facilitates negotiations by focusing on general principles and rules rather than on case-specific outcomes. Because the parties do not know their precise future environmental positions, the process benefits from something of a Rawlsian veil of ignorance that supports principled decisionmaking. ${ }^{62}$

If spillovers from one jurisdiction to another represent a serious issue, decentralized collaborative policy responses are likely to be suboptimal for the same reasons that common law approaches to environmental problems do not work: high transaction costs and unclear property rights. Whenever we create multiple regulatory jurisdictions in an attempt to better tailor policies to local needs and desires, our ability to limit transjurisdictional pollution to an efficient level and to protect property rights diminishes. At the very least, the gains from reduced internalities must be offset against the losses from increased externalities.

Agreement on the principle that externalities generally justify some degree of regulatory centralization does not, however, solve the policy problem. There remains the issue of what sorts of externalities create structural failures and how best to respond to them.

with Mexican environmental laws and the only violation was of U.S. visibility standards. See ESTY, supra note 52, at 187.

62. See Roger Fisher \& William Ury, Getting to Yes: Negotiating AGREEMENT WITHOUT GIVING IN (1981) (spelling out the advantages of negotiating about principles rather than positions). Of course, in some cases the parties do know their specific future positions and thus will negotiate principles with their own needs in mind. For example, the Chinese government cannot be expected to negotiate rules about climate change that fail to reflect China's heavy dependence on coal. 
a. Physical Spillovers. Transboundary pollution represents the paradigmatic externality. The physicality of the spillover and the tangibility of the harm make vivid the potential threat to allocative efficiency and to property rights, and clearly justify regulation if transaction costs are high. The more widespread the physical risks posed by a given pollutant, the larger the scope of governmental activity must be to account for every affected property interest. Thus, the extent of the externality - the harm caused or benefit provided - represents a critical determinant of the scale of the optimal governmental response. To be structurally adequate, an environmental policy must encompass the costs and benefits felt by all potential victims and cost-bearers. ${ }^{63}$

b. Economic Externalities. While physical-pollution spillovers represent the classic externality, structural issues do not arise solely from the physical reach of environmental harms. ${ }^{64}$ From a utility-maximizing perspective, parties suffering from economic ${ }^{65}$ or psychological spillovers also should have their interests factored into the regulatory calculus. For example, if a landowner allows industries located on her property to forego the use of costly pollution-reducing technologies, other landowners may be affected. Even if the resulting pollution does not spill onto their land, they face a choice between adopting a similar policy and suffering the environmental effects, or rejecting it and suffering potential competitiveness effects. The use of environmental resources in the first instance has external economic effects on other parties, even when no pollution actually travels. ${ }^{66}$

63. This matching principle is widely accepted with regard to physical spillovers. See Olson, supra note 40, at 48, 53-57 (noting that political boundaries must be coterminous with the scope of a public good to ensure optimal investment in the collective good); see also BAUMOL \& OATES, supra note 8; Revesz, supra note 1, at 1250-53; Stewart, Pyramids, supra note 7.

64. Stewart, for example, identifies three sorts of externalities beyond traditional pollution spillovers: resource externalities (for example, wasteful consumption of resources by others), preservation externalities (for example, when resources consumed in one jurisdiction deprive others of "nonuse values" they might have enjoyed), and competitiveness externalities (for example, when states set suboptimal environmental standards due to fears of job loss and industrial dislocation). See Richard B. Stewart International Trade and the Environment: Lessons from the Federal Experience, 49 WASH \& LEE L. REV. 1329, 1340-41 (1992).

65. See EsTY, supra note 52; infra note 134 (explaining that the main impact of the race to the bottom is on the environmental policymaking dynamic and not on industry competitiveness per se).

66. Indeed, it was problems of this sort that motivated the first U.S. federal environmental laws. Specifically, Senator Ed Muskie feared that Maine pulp mills, which were subject to relatively stringent environmental controls, might suffer in competition with mills in the less rigorously regulated West. See ESTY, supra note 52, at 22, for a legislative history of these competitiveness arguments. 
Some commentators argue that such economic externalities are somehow less "real" than physical spillovers. Revesz, for instance, makes a theoretical distinction between "technological (or real)" externalities, such as pollution from an upwind state, and "pecuniary externalities," in which "one individual's decisions affect the financial circumstances of the other, but there is no misallocation of resources." 67 When an increase in the number of shoes demanded increases the price of leather and thus affects the welfare of handbag buyers, Revesz argues that there is no real externality present. He claims that this is simply a market-clearing mechanism which is by definition welfare-optimizing, assuming a free market for leather, shoes, and handbags. Nevertheless, a range of real externalities exists that goes beyond physical pollution spillovers. ${ }^{68}$

Many pollution-control or resource-use decisions have economic impacts that cannot be dismissed simply as a function of welfareenhancing resource reallocation. California's adoption of auto emissions standards that exceed national requirements may reflect the fact that Californians stand to benefit greatly from lower emissions and to pay relatively little of the extra pollution control costs that will be borne largely by out-of-state automakers. ${ }^{69}$ In this case, there is no market mechanism to ensure that California's action is nationally welfareenhancing. Californians may pay part of the bill for their more stringent pollution controls through higher prices for cars, but consumers elsewhere may also be forced to pay increased prices, essentially subsidizing California's reduced-pollution benefits. ${ }^{70}$ In particular, we have no guarantee that the benefits to California outweigh the sum of the costs imposed both inside and outside of California. An excessively narrow understanding of "real" externalities, such as that provided by Revesz, misses such cases."

c. Psychological Externalities: The "Choice of Public" Issue. In some cases, the harm suffered by people beyond the borders of the reg-

67. Revesz, supra note 1 , at 1223 . In support of this distinction, see BAUMOL \& OATES, supra note 8 , at $21-23,155-234$.

68. See Stewart, supra note 64 , at $1340-41$.

69. See E. Donald Elliott et al., Toward a Theory of Statutory Evolution: The Federalization of Environmental Law, 1 J.L. ECON. \& ORG. 313 (1985).

70. If the extra price for the "California car" were fully borne by Californians that is, internalized - there would be no efficiency problem, but given national marketing programs and other constraints, automakers end up selling California cars at a discount.

71. For further arguments defining various types of economic spillovers, see Steve Charnovitz, Trade Measures and the Design of International Regimes, 5 J. ENVT. \& DEV. 153 (1996). 
ulating jurisdiction is neither physical nor economic, but rather is psychological..$^{72}$ Americans deplore the killing of whales in international waters. Europeans, in large numbers, express outrage at the use of painful leghold traps to capture beaver and mink for furs. The welfare loss in these cases is undeniable. The question is whether those suffering the harm have a legitimate interest in the policy decision made elsewhere. More precisely, do they have a right to have their feelings factored into the policy calculus?

Whether an externality exists, and thus whether a regulatory process that disregards psychological harms has failed structurally, depends on the reach of the property rights in question..$^{73}$ If those with legitimate claims are ignored, the regulatory calculus will be off-kilter. ${ }^{74}$ In the case of public goods or resources, the question of legitimate interests and thus of "missing voices" among those with property rights may be even murkier. If a public resource belongs to us and is to be managed in our interests, who is "us"?

Frequently the boundaries of an environmental resource are not fixed. Who, for example, holds legitimate interests vis-à-vis the Grand Canyon? Even if we accept that an environmental resource must be, or should be, publicly held and managed, there remains an issue about the proper management entity. Part of the current environmental controversy in the United States centers not only on whether public lands and other environmental resources should be owned and managed privately as opposed to by the government, but also on the appropriate scope of the decisionmaking community. ${ }^{75}$ Resource managers could represent:

72. See Richard Blackhurst \& Arvind Subramanian, Promoting Multilateral Cooperation on the Environment, in THE GREENING OF WORLD TRADE ISSUES 247 (Kym Anderson \& Richard Blackhurst eds., 1992); Walter P.J. Wils, Subsidiarity and EC Environmental Policy: Taking People's Concerns Seriously, 6 J. ENVTL. L. 85 (1994).

73. Permitting unusual or irrational psychological harms to drive regulatory policy seems especially troubling. Beyond the property rights issue, such concerns reflect a fear that our regulatory decisions might be distorted by inaccurate data on psychological harms and a worry that psychological harms might be overstated. Indeed, without a "willingness to pay" mechanism to check the reality and depth of such harms, there exists a moral hazard problem of potentially significant proportions because those claiming injury have little reason to report accurately on their welfare losses and much reason to exaggerate. Nevertheless, as Michael Gerrard notes, while fears of living near a hazardous waste dump or a nuclear waste depository may be irrational, the disutility is real. See Michael B. Gerrard, Whose BACKyARD, Whose Risk 100-07 (1994).

74. See John D. Graham \& Jonathan BaERT Wiener, RisK Versus RisK 230-32 (1995) (discussing the similar problem of "omitted voices" in risk analyses).

75. Another issue is the decisionmaker's location. Some of the current publiclands management concern reflects dissatisfaction with the concentration of day-to-day decisionmaking in Washington, D.C., and a belief that it would be better undertaken by those "on the scene." But decentralizing control to avoid micromanagement from 
(1) the narrow class of citizens who physically use the resource; (2) members of the town in which the common property is located; (3) the citizens of the state; or (4) the entire country.

Community identity is fixed in neither time nor space. Given the threshold effects and lag times that characterize many resource-use and environmental problems, the temporal dimension of environmental protection is often significant. Some of the CFCs released into the atmosphere in the 1980s still will be eating away the ozone layer at the end of the twenty-first century. Present generations may ignore or discount growing public health or ecological harms at the expense of future generations. ${ }^{76}$ Spatial extensions of our sense of community also may be important in light of ever broader transportation networks and communication systems. People today live and work in different communities and sometimes even different states or countries. In addition, the mobility of society means that many people have friends, relatives, and important ties to places quite removed from their immediate surroundings. Moreover, many people live in several communities, states, and even countries over the course of their lives. All of these dimensions of mobility create an expanded sense of community and therefore of political identity. ${ }^{77}$ As a result, "we" become "they," and vice versa. Media coverage of environmental news, which is increasingly national or even international, further expands political identity. ${ }^{78}$

Washington and to ensure that federal authorities coordinate with state and local officials should not be confused with having central government resources managed for the benefit of the state in which they happen to be located. Just as federal money in New York banks is managed for the benefit of the national treasury and not for the welfare of New Yorkers, federal lands should be managed for the American public at large. As a separate matter, one might consider selling federal lands that do not have national significance.

76. Thus, in some cases, as Edith Brown Weiss and other commentators have noted, the relevant political constituency should be expanded to include future generations. See EDITH BROWN WEISS, IN FAIRNESS TO FUTURE GENERATIONS: INTERNATIONAL LAw, COMMON PATRIMONY, AND INTERGENERATIONAL EQUITY (1989). The problem arises because bequest motives may not be strong enough to ensure that the current populace adequately represents the interests of future generations. See, e.g., Peter A. Diamond, A Framework for Social Security Analysis, 8 J. PuB. ECON. 275 (1977). But see Harold P. Green, Legal Aspects of Intergenerational Equity Issues, in EQUITY Issues IN RADIOACTIVE WASTE MANAGEMENT 189 (Roger E. Dasperson ed., 1983) (arguing that the absolutism of some laws overvalues the future).

77. My argument is not that people should be more "communitarian," but simply that they, as a matter of fact, perceive themselves to be part of various communities. See Michael J. Sandel, Democracy's Discontent: America in Search of A Public Philosophy (1996); Michael J. SANDEl, Liberalism and the Limits OF JUSTICE 59-65 (1982).

78. See Daphne Abeel, Ideas, The Media, Christian Sci. Monitor, Dec. 7, 1984, at 34; James R. Campbell, Newspapers: The Battle for Time, UNITED PRESS 
The relevant political community is not, of course, inexorably expanding. Individuals' sense of community and political identity can shrink as well as expand. The claims of some self-styled constituents may be rejected by others as the views of outsiders. Furthermore, "distant" parties should not necessarily see their preferences prevail. It is clear, however, that in environmental policymaking, the sphere of affected interests may expand or contract depending on an evolving definition of community. Moreover, these two considerations intertwine: as more externalities or internalities are perceived, political identity may change accordingly; and as political identity changes, new structural inadequacies may come to light. In attempting to maximize environmental social welfare, we should be careful not to conclude too hastily that we know the precise boundaries of the appropriate community and thus whose costs and benefits should "count."

\section{Public Choice Problems}

Added to the problem of the right "choice of public" is the problem of public choice. The two issues are conceptually distinct. The former is essentially a matter of clarifying whose interests should count in the regulatory process. The latter, however, may exist even though the choice of public issue has been resolved, correctly or otherwise. Optimal regulation depends on the public's political preferences being faithfully and accurately translated into policy outcomes.

Environmental regulation has several features that generate public choice issues. Notably, the costs of environmental regulation are generally more concentrated and tangible than the benefits. ${ }^{79}$ Costs are often borne by particular industries or enterprises, and are translated readily into monetary terms. Benefits, however, accrue to the general public in

INTL., Apr. 24, 1989; Tom Curley, One Million New Readers Added in 1989, USA ToDAY, Jan. 8, 1990, at 13A.

79. This asymmetry has long been recognized. See JAMES BUCHANAN \& Gordon Tullock, The Calculus of Consent (1962); Bruce Ackerman, Beyond Carolene Products, 98 HARV. L. REV. 713, 723-26 (1985) (observing the advantage concentrated interests have over diffuse ones); see also Roger G. Noll, Economic Perspectives on the Politics of Regulation, in HANDBOOK OF INDUSTRIAL ORganizaTION 1265 (Richard Schmalensee \& Robert D. Willig eds., 1989) (stating that "large, heterogeneous groups with relatively small per capita stakes . . . will be disadvantaged relative to small, homogeneous groups with high per capita stakes"). When the reverse is true - that is, the benefits of controls are concentrated and the costs diffuse - the opposite public choice problem, a NIMBY ("not in my backyard") situation, may arise, resulting in systematic overregulation. See, e.g., James T. Hamilton, Missing the Mark(et) in Siting Hazardous Waste Facilities, 1 DuKE ENVTL. L. \& POL. F. 11 (1991). 
ways that are hard to discern and monetize..$^{80}$ These asymmetries in information and the concentration of regulatory costs and benefits may give rise to asymmetries of political activity and influence between polluters and pollutees or between common-resource users and the public owners of these resources. ${ }^{81}$ Because these asymmetries may be more significant at the state and local levels, ${ }^{82}$ decentralization may represent a strategy to advance deregulation for the benefit of certain special interests. $^{83}$

For most people, moreover, environmental quality comprises only a limited dimension of their welfare. Economic prosperity and material well-being are far more important determinants of their quality of life. Thus, few people vote or choose where to live on the basis of environmental factors alone ${ }^{84}$ The resulting "bundling" of issues at election time works against the seamless translation of the public's environmental views into environmental policy. ${ }^{85}$ In addition, unlike taxing and spending decisions and the issues in some other regulatory domains, the public has a hard time discerning its own interests in the environmental realm. Simply put, people can tell if the roads or schools are meeting their needs, but they cannot assess the adequacy of a residue standard of seven parts per million for the pesticide EBDC. The more uncertain, technically complex, and nonintuitive the policy choice, and the greater the difficulty in reducing the decision to easily understood dollar terms, the higher the risk of special interest distortions.

80. Thus, the technical complexity and inherent uncertainty of environmental regulation, see supra text accompanying notes $28-30$, intersects with public choice problems to create additional regulatory failures. The particular obscurity of the political process in the environmental domain creates an especially wide opening for special interest intervention and distortion of the regulatory process.

81. See Daniel A. Farber, Economic Analysis and Just Compensation, 12 INTL. REV. L. \& ECON. 125, 130-31 (1992) (noting that landowners have greater power than the public at large).

82. See Stewart, Pyramids, supra note 7, at 1213; see also Warren L. Ratliff, The De-Evolution of Environmental Organization, J. LAND, RES,. \& ENVTL. L. (forthcoming 1997).

83. See, e.g., RosE-ACKERMAN, supra note 7, at 159-73 (arguing that the decentralization thrust in the Reagan Administration represented no grand theory of optimal regulation but rather a simple desire to help business interests).

84. See Joseph Kalt \& Mark Zupan, Capture and Ideology in the Economic Theory of Politics, 74 AM. ECON. REv. 279, 281-85 (1984); see also Noll, supra note 79, at 1270-72.

85. Bundling of issues tends to dilute the impact of any one issue. See, e.g., James D. Gwartney \& Richard E. Wagner, Public Choice and the Conduct of Representative Government, in PUblic Choice AND Constitutional Economics 3, 10, 19 (James D. Gwartney \& Richard E. Wagner eds., 1988); Robert D. Tollison, Rent Seeking: A Survey, 35 KYKLOS 575, 594 (1982). 
The threshold effects and time lags associated with pollution exacerbate these problems. Governmental officials rarely are eager to pay the political price for spending money today to fix a problem that will emerge, if at all, at some future date. From a politician's perspective, there is little incentive to impose costly controls on greenhouse gas emissions that must be borne today when the benefits will not show up until $2050,{ }^{86}$ let alone in time to claim credit in the next election two or four years hence. ${ }^{87}$ When pollutants have very long lifetimes, ${ }^{88}$ intergenerational equity and additional public choice issues emerge.

In sum, environmental protection involves a wide range of problems demanding an equally diverse set of response strategies. Arguments that decentralization or any other "silver bullet" environmental reform might set us on the right course misapprehend the nature of the policy challenge. ${ }^{89}$ Environmental problems are complicated and messy, as are the best solutions.

\section{Decentralization vs. Centralization: The Debate To DATE}

This Part identifies the origins and current state of the environmental federalism debate. Section II.A traces the development of centralized environmental regulatory initiatives and of the arguments marshaled in their support. Section II.B discusses the second-generation response to centralized environmental regulation and examines the five core secondgeneration arguments in support of decentralization.

86. Of course, how significant the problem of climate change will prove to be remains uncertain and thus creates a further reason for politicians to disregard the problem.

87. In economic terms, politicians have a high discount rate. The difference between the discount rates of the public and of political leaders is one of the systemic public choice problems associated with environmental regulations. See, e.g., W. Kip Viscusi, Equivalent Frames of Reference for Judging Risk Regulation Policies, 3 N.Y.U. ENVTL. L.J. 431, 437 (1995) (arguing that the time lag between asbestos regulation and benefits "substantially reduce[s] . . value and the relative attractiveness of the regulation").

88. Some CFCs and greenhouse gases persist in the atmosphere for hundreds of years, and radioactive wastes may be harmful for thousands of years. See, e.g., Owen Davies, Air Repair, OMNI, June 1993, at 62, 94; A.R. Ravishankara et al., Atmospheric Lifetimes of Long-Lived Halogenated Species, 259 SCIENCE 194 (1993).

89. To the academic reader, this point may seem banal. But this article is written against the backdrop of a political debate over the proper locus for environmental regulation in which some of the loudest voices are calling, without nuance, for total decentralization. See, e.g., GiNGRICH, supra note 1, at 9 ("We must replace our centralized, micromanaged, Washington-based bureaucracy with a dramatically decentralized system ...."); see also H.R. 473-480, 104th Cong. (1995) (legislation sponsored by Congressman Tom DeLay abolishing wholesale Federal Clean Air regulation). 


\section{A. First-Generation Thinking: The Development of and Arguments for Centralization}

Until quite recently, the harms that accrued from air and water pollution were addressed not by environmental regulation but through the most decentralized of control mechanisms: nuisance law. ${ }^{90}$ Beginning in the 1880s and 1890s, a number of cities, including Chicago, New York, and Pittsburgh, adopted "smoke abatement" ordinances. ${ }^{91}$ Garbage dumping also became subject to local regulation..$^{92}$ These early attempts at environmental regulation reflected the recognition that common law private nuisance actions could not respond efficiently to the pollution problems of an industrial society. ${ }^{93}$

Although some states adopted air and water pollution laws as early as the end of the nineteenth century, state regulation of environmental problems did not begin in earnest until the post-World War II industrial boom. ${ }^{94}$ The state regulatory efforts of the 1950s and 1960s, however, did little to stem the flow of pollution, ${ }^{95}$ and by the mid-60s, the

90. Tort-law based, case-by-case, pollution-harm determinations made through private nuisance lawsuits represent the ultimate decentralization of "regulation." See, e.g., Madison v. Ducktown Sulphur, Copper \& Iron Co., 83 S.W. 658 (1904); St. Helen's Smelting Co. v. Tipping, 35 L.G.Q.B. 66, 11 H.L. Cas. 642, 13 Wkly. Rep. 1083 (1865); Aldred's Case, 9 Co. Rep. 57 b., 77 Eng. Rep. 816 (K.B. 1611). Public nuisance cases involving states rather than individuals represent the first step toward centralization of the response to environmental harms. See Georgia v. Tennessee Copper Co., 206 U.S. 230 (1907); Missouri v. Illinois, 200 U.S. 496 (1906).

91. See Robert V. Percival et al., EnVironmental Regulation: Law, Science, AND Policy 103-04 (1992); Arnold W. Reitze, Jr., A Century of Air Pollution Control Law: What's Worked; What's Failed; What Might Work, 21 ENVTL. L. 1549, 1576 (1991).

92. See Martin V. Melosi, Garbage in the Cities: Refuse, Reform and THE ENVIRONMENT, 1880-1980 (1981); Christopher Niemczewski, The History of Solid Waste Management, in THE ORgANIZATION AND EFFICIENCY OF SOlID WASTE MANAGEMENT (Emanuel S. Saras ed., 1977).

93. The difficulty with reliance upon tort remedies as a pollution control strategy was remarked upon as early at 1862 by the British House of Lords Select Committee on Injury From Noxious Vapours, which noted: "partly in consequence of the expense such actions occasion, partly from the fact that where several works are in immediate juxtaposition, the difficulty of tracing the damage to any one, or of apportioning it among several, is [so] great as to be all but insuperable." House OF LORDS SELECT COMM. ON INJURY FROM NOXIOUS VAPOURS, 1862 REPORT v (1862), reprinted in [1862] 14 Parl. Papers 1, 3, quoted in Joel Franklin Brenner, Nuisance Law and the Industrial Revolution, 3 J. LEGAL STUD. 403, 425 (1974).

94. Oregon created the first state environmental (air pollution control) agency in 1952. In 1955, the California legislature charged the State Department of Public Health with establishing air pollution standards. See Health \& Safety Code, ch. 1312, sec. 1, $\S 425,1955 \mathrm{Cal}$. Stat. 2385, repealed by ch. 1545, § 1, 1967 Cal. Stat. 3679.

95. See Environmental Protection Agency, National Air Pollution TRENDS, 1900-1992, at ES-4 (1993) [hereinafter EPA]. 
demand for more centralized regulation was growing. ${ }^{96}$ In 1963, Congress adopted the first Clean Air Act, ${ }^{97}$ authorizing the Secretary of the Department of Health, Education, and Welfare, as it was then called, to establish advisory air quality "criteria" and to convene "conferences" when interstate pollution endangered public health or welfare. ${ }^{98} \mathrm{Simi-}$ larly, the Water Quality Act of 1965 required states to adopt federally approved water quality standards for any body of water that moved across state boundaries.99

These federal efforts to support and prod state-level environmental regulation produced unsatisfactory results. Air and water quality around the country continued to deteriorate. ${ }^{100}$ Congressional hearings in the late 1960s and early 1970s spelled out three broad reasons for further centralizing environmental regulation: interstate spillovers of pollution; ${ }^{101}$ the poor performance of states as environmental regulators; ${ }^{102}$

96. The first federal environmental programs tended simply to support state regulation. See, e.g., Federal Water Pollution Control Act of 1948, Pub. L. No. 80-845, 62 Stat. 1155 (current version at 33 U.S.C. $§ 1251$ (1995 \& Supp. 1996)) (supporting research on water pollution and providing grants to states to support water pollution control programs); Air Pollution Control Act of 1955, Pub. L. No. 84-159, 69 Stat. 322 (current version at 42 U.S.C. $§ 7401$ (1995)) (providing funds for research and technical assistance to states); Motor Vehicle Act of 1960, Pub. L. No. 86-493, 74 Stat. 162 (federal research into air pollution from automobiles); Tom Jorling, The Federal Law of Air Pollution Control, in Federal Environmental Law 1058 (Erica L. Golgin \& Thomas G.P. Guilbert eds., 1974); Percival, supra note 5, at 1155-57.

97. Pub. L. No. 88-206, 77 Stat. 392 (1963) (codified as amended in scattered sections of 42 U.S.C. $\$ \S 7401-7671$ (1994)).

98. See Pub. L. No. 88-206, 77 Stat. 392, 395-96 (1963) (codified as amended in scattered sections of 42 U.S.C. $\$ \S 7401-7671$ (1994)).

99. See Water Quality Act of 1965, Pub. L. No. 89-234, 79 Stat. 903 (codified at 33 U.S.C. § 466, transferred to $\S \S 1151-1160$, and subsequently omitted by Pub. L. No. 92-500, \& 2, 86 Stat. 816 (1972)).

100. See EPA, supra note 95; JoHN C. EsPosrto, VANISHING AIR 118-51 (1970); Joshua D. Sarnoff, The Continuing Imperative (But Only from a National Perspective) for Federal Environmental Regulation, 7 DUKE ENVTL. L. \& POLY. F. (forthcoming 1997); see also Frank J. Barry, The Evolution of the Enforcement Provisions of the Federal Water Pollution Control Act: A Study of the Difficulty in Developing Effective Legislation, 68 MiCH. L. REV. 1103 (1970).

101. See, e.g., Air Pollution, 1967: Hearings Before the Subcomm. on Air and Water Pollution of the Senate Comm. on Public Works, 90th Cong. 993 (1967) (testimony of Lewis C. Green of the Missouri Air Conservation Commission):

[A]ir pollution is a problem that rarely falls within ready-made political boundaries. In any metropolitan area both the social costs incurred in failing to control it and the benefits to be derived from regulation within a single political subdivision inevitably spill over into other jurisdictions . . . . The necessity for . . . uniformity is rather generally agreed upon.

Many other similar remarks can be found in the environmental hearing reports of the 1960 s and 1970s.

102. See, e.g., id. at 796 (statement of Dr. Ivan L. Bennett, Jr., Deputy Director Office of Science and Technology, Executive Office of the President) ("[T]he states 
and interstate competitiveness effects arising from differing environmental standards. ${ }^{103}$ Based on the Congressional consensus established on these points, the Clean Air Act of $1970^{104}$ and the Clean Water Act of $1972^{105}$ shifted the center of gravity for environmental regulation from the states to the federal government. Additional federal statutes followed: the Federal Environmental Pesticide Control Act of 1972, ${ }^{106}$ the 1974 Safe Drinking Water Act ${ }^{107}$, the 1976 Resource Conservation and Recovery Act, ${ }^{108}$ and the 1980 Comprehensive Environmental Response, Compensation, and Liability Act. ${ }^{109}$

Other forces also spurred centralization. Elliott, Ackerman, and Millian suggest, for example, that the federalization of environmental law may have reflected industry preferences for unified national standards that would preempt varying state requirements. ${ }^{110}$ Rose-Ackerman identifies additional strategic incentives facing a number of actors who supported centralized environmental regulation over disjointed state processes. ${ }^{111}$ Finally, presidential politics - the positioning of the Senate's leading environmentalist, Ed Muskie of Maine, as a challenger to

simply have not moved . . . [ [T]he incentive of matching grants has not succeeded in bringing about the results that it had been hoped would be achieved."). The suggestion that states might choose low environmental standards as a matter of policy was not recognized at all.

103. See, e.g., S. REP. No. 91-1196 (1970); Air Pollution, 1970: Hearing on S.3229, S.3466, S.3546 Before the Senate Subcomm. on Air and Water Pollution of the Senate Comm. on Public Works, 91 st Cong. 487 (1970). Rep. Abner J. Mikva of Illinois observed, for example, that "[w]hen states are competing daily to attract new industry, it is unrealistic to expect that strict enforcement of antipollution regulations - which imposes financial burdens sometimes higher than taxes themselves - will occur." Air Pollution Control and Solid Wastes Recycling: Hearings Before the Subcomm. on Public Health and Welfare of the House Comm. on Interstate and Foreign Commerce, 91st Cong. 487 (1970); see also BAUMOL \& OATES, supra note 8, at 14-35; Revesz, supra note 1 .

104. Pub. L. No. 91-604, 84 Stat. 1676 (codified as amended in scattered sections of 42 U.S.C. $\S \S 7401-7642(1994))$.

105. Pub. L. No. $92-500,86$ Stat. 816 (codified as amended in scattered sections of 33 U.S.C. $\S \S 1251-1376(1994))$.

106. Pub. L. No. $92-516,86$ Stat. 973 (codified as amended at 7 U.S.C. $\S \S 136-$ 136y (1994)).

107. Pub. L. No. 93-523, 88 Stat. 1660 (codified as amended at 40 U.S.C. $\S \S 300 \mathrm{f}-300 \mathrm{j}(1994))$.

108. Pub. L. No. 94-580, 90 Stat. 2795 (codified as amended in scattered sections of 42 U.S.C. $\$ \S 6901-6987$ (1994)).

109. Pub. L. No. 96-510, 94 Stat. 2767 (codified as amended in scattered sections of 42 U.S.C. $\S \S 9601-9675$ (1994)).

110. See Elliott et al., supra note 69, at 326-27.

111. See Susan Rose-Ackerman, Does Federalism Matter? Political Choice in a Federal Republic, 89 J. Pol. ECON. 152 (1981); see also Jerry L. Mashaw \& Susan Rose-Ackerman, Federalism and Regulation, in THE REAGAN REgulatORY STRATEGY 111, 122-27, 133-36 (George C. Eads \& Michael Fix eds., 1984). 
President Richard Nixon in 1972 - helped to ensure that a strong federal Clean Air Act moved through the Congress. ${ }^{112}$

The legal literature caught up with the centralization policy trend in 1977 with the publication of two seminal articles by Richard Stewart. ${ }^{113}$ Stewart identified four core rationales for centralized environmental law: (1) to address the tragedy of the commons and achieve national economies of scale; (2) to overcome disparities in effective political representation; (3) to correct market failures arising from pollution externalities (including physical, "psychic," and economic spillovers); and (4) to obtain the advantages of pursuing moral ideals and the "politics of sacrifice" on a national plane. ${ }^{114}$

Stewart's argument begins with the prisoners' dilemma dynamic, ${ }^{115}$ now better known in the environmental context as the "race to the bottom." He observes as follows:

Given the mobility of industry and commerce, any individual state or community may rationally decline unilaterally to adopt high environmental standards that entail substantial costs for industry and obstacles to economic development for fear that the resulting environmental gains would be more than offset by the movement of capital to other areas with lower standards. ${ }^{116}$

The tendency not to adopt strict environmental controls or to move toward lax environmental requirements derives from the fact that governments act strategically. Regulators and the politicians who appoint them perceive that by cutting environmental standards and stealing a march on other jurisdictions in the competition for new investment,

112. See Elliott et al., supra note 69 , at 327-28.

113. See Stewart, Pyramids, supra note 7; Stewart, Development, supra note 7. Debates over how much to centralize or decentralize government activity in general go back much further, particularly in political science literature. See ALEXIS DE TOCQUeVILle, Democracy in America 163 (Phillips Bradley ed., Henry Reeve \& Francis Bowen trans., Alfred A. Knopf 1945) (1835) (comparing governance of "centralized nations" and "confederations"); PAUL E. PETERSON ET AL., WHEN FEDERAlism Works 1-7 (1986); see also Robert A. DAHL \& Charles E. LindBlom, Politics, Economics and Welfare (1953); Paul E. Peterson, City Limits 338, 66-92 (1981); James Fesler, Centralization and Decentralization, in 2 INTERNATIONAl ENCYClOPEDIA OF THE Social Sciences 370 (David L. Sills ed., 1968); Grodzins, supra note 5; Scheiber, supra note 4.

114. See Stewart, Pyramids, supra note 7, at 1211-19.

115. For more on this dynamic, see Mashaw \& Rose-Ackerman, supra note 111, at 117-18; see also Scott Barrett, Strategic Environmental Policy and International Trade, 54 J. PuB. Econ. 325 (1994) [hereinafter Barrett, Strategic Environmental Policy]; Scott Barrett, Strategy and Environment, 27 ColuM. J. WORLD Bus. 202 (1992) [hereinafter Barrett, Strategy and Environment]. For a general discussion of prisoners' dilemmas and strategic behavior, see DIXIT \& NALEBUFF, supra note 31.

116. Stewart, Pyramids, supra note 7, at 1212. 
jobs, and industrial activity, they will increase their constituents' welfare by more than the utility losses inflicted by whatever environmental degradation occurs. The knowledge that one's competitors intend to lower or already have lowered environmental standards induces parties to act preemptively or responsively and to lower their own standards, triggering a downward regulatory spiral and nonoptimal results. ${ }^{117}$ Stewart recognizes that national environmental laws facilitate the collective action necessary to escape from this race. ${ }^{118}$ While parties theoretically can negotiate their way out of this prisoner's dilemma, the nature of environmental problems, involving "recurring technically complex issues," makes ad hoc welfare-optimizing compacts among competing jurisdictions improbable and centralized regulation cost-effective. ${ }^{119}$

Stewart's second focus is the disjunction between the political power of polluters and environmental interests. ${ }^{120} \mathrm{He}$ notes that environmental advocates who try to rally the public in support of relatively diffuse and obscure benefits experience difficulty in achieving a critical threshold of political activity and influence at local or state levels, ${ }^{121}$ and are more often able to aggregate sufficient resources to be effective at the national level. ${ }^{122}$ Whether an asymmetry of political power be-

117. The race to the bottom represents a structural failure insofar as competition among jurisdictions creates economic externalities. Stewart also folds into his first point a discussion of economies of scale in regulatory activities that tracks my technical inadequacy category. See id.

118. See id.; see also Alfred C. Aman, Jr., Administrative Law in a Global Era: Progress, Deregulatory Change, and the Rise of the Administrative Presidency, 73 CoRNELL L. Rev. 1101, 1194 (1988); William W. Bratton \& Joseph A. McCahery, Regulatory Competition, Regulatory Capture, and Corporate Self-regulation, 73 N.C. L. REv. 1861 (1996); Cass R. Sunstein, Constitutionalism After the New Deal, 101 HARv. L. REv. 421, 505 (1987); Roger van den Bergh et al., The Subsidiarity Principle in European Environmental Law: An Economic Analysis 20-24 (1995) (paper prepared for Conference on the Law and Economics of the Environment at the Norwegian Academy of Science and Letters, on file with author) (providing European examples of this phenomenon).

119. See Stewart, Pyramids, supra note 7, at 1212. As suggested earlier, Coase demonstrates that absent transactions costs, efficient outcomes can be negotiated. See Coase, supra note 18.

120. See Stewart, Pyramids, supra note 7, at 1213; see also supra text accompanying notes 79-89. This is the public choice problem in my taxonomy.

121. See Stewart, Development, supra note 7, at 747.

122. See, e.g., Phillip Shabecoff, A Fierce Green Fire 279 (1993). This perceived imbalance has deep roots. Nearly a century ago, Gifford Pinchot, President Theodore Roosevelt's first director of the National Forest Service, decried the "special interests" operating in the political realm that threatened to "nullify the will of the majority" with regard to conservation and environmental policy. See id; see also BRUCE A. Ackerman \& William T. Hassler, Clean Coaldirty Air (1981); J. Clarence Davies III \& Barbara S. Davies, The Politics of Pollution (1975); Richard B. Stewart, The Reformation of American Administrative Law, 88 HARV. L. 
tween environmental and polluting interests continues to exist, and more important, whether this asymmetry is greater at the local or state level than at the national level, remains an issue today.

Stewart's third point concerns the widely recognized market failure associated with pollution externalities. ${ }^{123}$ His final rationale builds on the claim that it is easier to carry out policies aimed at establishing overarching moral principles on a national level than a state or local one. He argues that the fundamental moral obligations of one citizen to another and to future generations must be defined nationally and embodied in federal law. ${ }^{124}$

\section{B. Second-Generation Thinking: Rationales for Decentralization}

From nearly the day that the ink was dry on Stewart's arguments justifying federal environmental regulation, the tides of political thinking and legal scholarship have run the other way. ${ }^{125}$ This secondgeneration thinking ${ }^{126}$ centers on five arguments for decentralization: (1) the benefits of diversity and diseconomies of regulatory scale; (2) arguments for regulatory competition and against race-to-the-bottom fears; (3) public choice claims regarding the representativeness of decentralized decisionmaking; (4) rejection of morality-based arguments for federal regulation; and (5) an implicit assumption that transboundary pollution spillovers are insignificant. ${ }^{127}$

Rev. 1669, 1684-87, 1713-15 (1975); Peter H. Schuck, The Politics of Regulation, 90 YALE L.J. 702 (1981) (book review).

123. This third line of analysis, concerning physical externalities, would be a matter of structural failure in my regulatory failure taxonomy.

124. Just as the advancement of civil rights required federal action, so too does environmental progress. Stewart specifically observes that citizens seem more willing to make sacrifices for unquantifiable gains if they know that others are doing the same, an observation that might support federal policymaking in various environmental areas. See Stewart, Pyramids, supra note 7, at 1264-65. In some respects, Stewart's pyramids-ofsacrifice argument resembles the "choice of public" question and thus represents a matter of psychological externalities raising the possibility of structural deficiencies in the regulatory regime.

125. Actually, the decentralization arguments predate Professor Stewart. The seminal article in this field is that of Tiebout, supra note 8.

126. See supra note 12; see also Richard Briffault, Our Localism: Part II - Localism and Legal Theory, 90 ColuM. L. REV. 346 (1990); Frank H. Easterbrook, Antitrust and the Economics of Federalism, 26 J.L. \& ECON. 23, 33-35 (1983). For a recent discussion, see David L. Markell, States as Innovators: It's time for a New Look to Our "Laboratories of Democracy" in the Effort to Improve Our Approach to Environmental Regulation, 58 ALB. L. ReV. 347 (1994).

127. Although asserted vigorously in political circles, constitutional arguments about the limits of U.S. federal regulatory authority bear little on the normative question of the best level at which to regulate environmental problems so as to maximize social welfare. Moreover, the constitutional polemics have been aired sufficiently elsewhere 


\section{The Benefits of Diversity}

The diversity argument for decentralized regulation represents a rich vein in popular and academic analyses of U.S. federalism. The argument has two separable strands. First, courts, ${ }^{128}$ scholars, ${ }^{129}$ and politicians ${ }^{130}$ have long trumpeted the opportunities for regulatory innovation provided by the "states as laboratories." A decentralized regulatory strategy permits the simultaneous testing of various policy responses. ${ }^{131}$ In particular, if the central policy issue is one of regulatory design, the opportunity to experiment using state regulatory structures may be especially welfare enhancing. Second, economics teaches that when environmental background conditions, emissions levels, climate, weather, risk

and thus will not be dealt with in this article. See United States v. Lopez, $115 \mathrm{~S}$. Ct. 1624 (1995); Garcia v. San Antonio Metro. Transit Auth., 469 U.S. 528 (1985); National League of Cities v. Usery, 426 U.S. 833 (1976); Stewart, Development, supra note 7, at 750-56; Stewart, Pyramids, supra note 7; see also Akhil Reed Amar, Five Views of Federalism: "Converse 1983" in Context, 47 VAND. L. REv. 1229 (1994); Lynn A. Baker, Conditional Federal Spending After Lopez, 95 ColuM. L. Rev. 1911 (1995); William N. Eskridge, Jr. \& John Ferejohn, The Elastic Commerce Clause: A Political Theory of American Federalism, 47 VAND. L. REV. 1355 (1994).

128. See Federal Energy Regulatory Commn. v. Mississippi, 456 U.S. 742, 788-91 (1982) (O'Connor, J., concurring in part and dissenting in part); Connecticut Light \& Power Co. v. Federal Power Commn., 324 U.S. 515, 530 (1945); New State Ice Co. v. Liebmann, 285 U.S. 262, 313 (1932) (Brandeis, J., dissenting) ("It is one of the happy incidents of the federal system that a single courageous state may, if its citizens choose, serve as a laboratory; and try novel social and economic experiments .....").

129. See, e.g., Felix Frankfurter, The Public and Its Government 4950 (1930) ("[O]ur federalism calls for the free play of local diversity in dealing with local problems"); see also Henry M. Hart, Jr., The Relations Between State and Federal Law, 54 Colum. L. REV. 489, 493 (1954). For a more recent discussion, see Markell, supra note 126.

130. As a political argument, decentralization emerged with considerable vigor in the "new federalism" of the Reagan administration. See Ronald Reagan, Inaugural Address (Jan. 20, 1981), in INAUgural AdDREsSes OF THE PRESIDENTS OF THE UNITED States, S. Doc. No. 101-10, at 331 (1989); Exec. Order No. 12,612, 3 C.F.R. 252 (1987); Gray, supra note 4; see also THE REAGAN REgUlAtORY STRATEGY, supra note 111. It has had new life breathed into it with the election of a Republican Congress in 1994. See GINGRICH, supra note 1, at 9. The very similar arguments for "subsidiarity" in the European Union represent the same political thrust. See George A. Bermann, Taking Subsidiarity Seriously: Federalism in the European Community and the United States, 94 ColuM. L. REv. 331 (1994); Trachtman, supra note 3, at 460-63; W. Gary Vause, The Subsidiarity Principle in European Union-American Federalism Compared, 27 CASE W. RES. J. INTL. L. 61 (1995).

131. Diversity also might be seen as nature's approach to problem solving. Biologists often observe that natural systems develop competing approaches to problems with preferred solutions emerging through evolution over time. See, e.g., RICHARD Dawkins, Blind Watchmaker (1986); Paul R. Ehrlich, The Machinery of NAture (1986); Steven Jay Gould, Wonderful Life: The Burgess Shale AND NATURE OF HISTORY (1989) (observing that nature responds to change in a variety of ways through a process Gould calls "adaptive radiation"). 
preferences, policy priorities, and income levels diverge, regulations tailored to localized circumstances will improve social welfare. ${ }^{132} \mathrm{Al}$ though a centralized regulatory body might be capable of such tailoring, the scale diseconomies of centralization argue for local regulation. ${ }^{133}$

\section{Regulatory Competition Versus Race-to-the-Bottom Theory}

Second-generation theorists suggest that there is little or no reason to fear a regulatory race to the bottom. ${ }^{34}$ More pointedly, the secondgeneration literature hypothesizes that far from unleashing a welfare-

132. See Jagdish Bhagwati \& T.N. Srinivasan, Trade and Environment: Does Environmental Diversity Detract from the Case for Free Trade, in FAIR TRADE AND HARMONIZATION: PREREQUISITES FOR FREE TRADE? 159 (Jagdish Bhagwati \& Robert E. Hudec eds., 1996) [hereinafter FAIR TRADE AND HARMONIZATION]; Robert Mendelsohn, Regulating Heterogenous Emissions, 13 J. ENVTL. ECON. \& MGMT. 301, 301-12 (1986) (asserting that the welfare loss from common standards rises with the heterogeneity of the problem at hand); Nordhaus, supra note 28, at 8 ("Efficient policies are highly specific to particular sectors, regions, and time periods.").

133. The second-generation diversity argument corresponds to several categories of regulatory failure. First, the arguments about states as laboratories and diseconomies of scale speak to technical transaction costs. Second, the prospect that diverse subjurisdictions will not have regulations tailored to their circumstances and needs raises the possibility of internalities that appear as a structural failure in my typology but could, as noted earlier, be categorized also as a public choice problem.

134. See Judith M. Dean, Trade and the Environment: A Survey of the Literature, in INTERNATIONAL TRADE AND THE ENVIRONMENT 15 (Patrick Low ed., 1992); Daniel R. Fischel, The "Race to the Bottom" Revisited: Reflections on Recent Developments in Delaware's Corporation Law, 76 Nw. U. L. REv. 913 (1982); Patrick Low \& Alexander Yeats, Do "Dirty" Industries Migrate?, in INTERNATIONAL TRADE AND THE ENVIRONMENT, supra, at 89; Revesz, supra note 1, at 1213-27. Others conclude that there is no empirical evidence of companies moving to "pollution havens." See, e.g., Adam B. Jaffe et al., Environmental Regulation and the Competitiveness of U.S. Manufacturing: What Does the Evidence Tell Us?, 33 J. ECON. LITERATURE 132 (1995); Joseph Kalt, The Impact of Domestic Environmental Regulatory Policies on U.S. International Competitiveness, in INTERNATIONAL COMPETITIVENESS 221 (A. Michael Spence \& Heather A. Hazard eds., 1988). But see U.S. GENERAL ACCOUNTING OFFICE, REPORT ON THE FURNITURE FINISHING INDUSTRY (1990) (finding evidence of industrial migration to Mexico due to environmental costs); Paula M. Block, The Allure of Southeast Asia's Chemical Market, Chemical WeEK, Apr. 15, 1987, at 42. Moreover, the economics literature that casts doubt on the seriousness of competitiveness pressures misunderstands how the race to the bottom plays out. Firms rarely move based on environmental standards. Nor do governments overtly change their laws to keep businesses from migrating. Thus, the image of a "race" does not really make sense. Instead, governments relax their environmental enforcement. Or, even more commonly, governments choose not to adopt more stringent standards, even if more vigorous requirements would be welfare enhancing, because economic interests are heard while environmental ones are not. Empirical studies to measure this regulatory chill or "political drag" would require gathering data on events that did not happen - a difficult task. See EsTY, supra note 52, at 162-63. 
reducing race, interjurisdictional competition pressures governments to regulate efficiently and effectively. ${ }^{135}$

Regulatory competition theory traces back to Tiebout's revolutionary 1956 article arguing that a decentralized governmental system, with horizontally arranged jurisdictions trying to attract residents on the basis of differing tax and benefit structures, produces a Pareto-superior outcome. ${ }^{136}$ Later theorists have tried to extend the reach of Tiebout's analysis by relaxing some of the many assumptions on which his theory rests. ${ }^{137}$ Fischel, for example, applies Tiebout-type thinking to the environmental realm with a model that addresses pollution and industrial location. ${ }^{138} \mathrm{He}$ concludes, under still quite restrictive assumptions, that environmental externalities can be internalized in a welfare-optimizing fashion with polluters compensating residents for their environmental harms and thus making interjurisdictional competition desirable. ${ }^{139}$ Like Tiebout, Fischel assumes away any job-loss problem and builds his model on an assumption that individuals are perfectly mobile. Oates and Schwab try to combat these weaknesses with a model that allows for the immobility of labor and wage effects. ${ }^{140}$ In their two-issue world, communities determine tax rates on capital and environmental standards with an eye toward attracting an optimal mix of industry and pollution.

135. The suggestion of a race to the bottom is a bit of a misnomer. The better understanding of this argument is not that standards will end up literally at the bottom, but rather that they will be suboptimally low from a welfare perspective. Revesz and others do not reject the possibility that regulatory competition will cause governments to lower their standards. They simply suggest that any such lowering will enhance, not diminish, social welfare. See Revesz, supra note 1, at 1232; see also Henry N. Butler \& Jonathan R. Macey, The Myth of Competition in the Dual Banking System, 73 CORNELL L. REV. 677 (1988); Ralph K. Winter, The "Race for the Top" Revisited: A Comment on Eisenberg, 89 COLUM. L. REV. 1526 (1989) [hereinafter Winter, "Race to the Top"]; Ralph K. Winter, State Law, Shareholder Protection, and the Theory of the Corporation, $6 \mathrm{~J}$. LEGAL STUD. 251 (1977) [hereinafter Winter, State Law].

136. While many commentators, including Tiebout, suggest that the proper test of welfare is by reference to "Pareto superiority," Kronman and Coleman have demonstrated the limitations of the Pareto analysis. See Jules L. Coleman, Efficiency, Exchange, and Auction: Philosophical Aspects of the Economic Approach to Law, 68 CAL. L. REv. 221 (1980); Anthony T. Kronman, Wealth Maximization as a Normative Principle, 9 J. LEGAL STUD. 227, 228-35 (1980). The more appropriate principle is the Kaldor-Hicks test. See Jules L. Coleman, Markets, Morals and the Law 98105 (1988); Kronman, supra, at 235.

137. Tiebout's model examines a resident choosing a community that "best satisfies his preference pattern for public goods." Tiebout, supra note 8 , at 418 . Tiebout assumes full individual mobility, a wide choice of communities, full knowledge of each community's taxes and services, and that the public goods chosen have no externalities such as job or wage effects. See id. at 414.

138. See Fischel, supra note 8, at 119.

139. See id. at 125-27.

140. See Oates \& Schwab, supra note 4. 
Oates and Schwab conclude that under these conditions, a rational government sets a tax rate of zero on capital and then achieves a welfaremaximizing environmental policy by cutting pollution until lost wage income matches the gains from reduced pollution damage. No race to the bottom ensues. ${ }^{141}$

In what may constitute the central statement of second-generation thinking, Revesz builds on the preceding scholarship, the regulatory competition literature in the corporate and bank charter contexts, ${ }^{142}$ and game theory analysis of the race to the bottom ${ }^{143}$ to conclude that "there are no models consistent with race-to-the-bottom claims." 144 Interjurisdictional competition, he argues, produces efficient regulatory results and enhanced social welfare. ${ }^{145}$ From this theoretical observation, Revesz moves to a policy prescription that presumptively favors decentralized environmental regulation. ${ }^{146}$ Although other commentators, especially in the political world, do not articulate their claims quite as well or as carefully as Revesz, their similar conclusions have made calls for devolution a common refrain in the environmental realm.

\section{Public Choice Arguments in Support of Decentralized Regulation}

In addition to efficiency gains, advocates of regulatory devolution employ public choice theory to argue against centralized environmental regulation. Two arguments are commonly advanced: first, that decisions made at higher and more distant levels of government compromise selfdetermination and are less "representative" than those made closer to

141. See id. at 336-49. As Revesz observes, "[t]he central insight of the Oates and Schwab study is that jurisdictions that seek to maximize their welfare will not set suboptimally lax environmental standards." Revesz, supra note 1, at 1242.

142. See Revesz, supra note 1, at 1247-53.

143. See id. at 1229-47. Although Revesz suggests that his analysis raises doubts about the "plausibility of race-to-the-bottom claims," id. at 1233, I think he does the opposite. Revesz's payoff matrix shows that under some circumstances centralized regulation will prevent subjurisdictions from being "gamed" into setting suboptimal standards. Sophisticated adherents to the race-to-the-bottom theory would not argue that a race inevitably occurs in the absence of federal regulation, but rather that it sometimes will - exactly as Revesz's game theory analysis indicates.

144. Id. at 1244. Revesz further observes that if races to the bottom occur, addressing the environmental policy race with federal governmental intervention will only drive state-versus-state competition into other realms such as worker safety, minimum wage laws, or fair labor standards. As a result, all regulation would have to be centralized. See id. at 1245-47.

145. See id.

146. See id. at 1253. 
home; ${ }^{147}$ and second, that interest group distortions of political decisionmaking become more severe at higher levels of government.

Environmental problems often have important local dimensions that are more likely to be captured by giving decisionmaking authority to those close to the issue. ${ }^{148}$ Cleanup standards for a toxic waste dump should, for example, turn on what the future land use of the site is likely to be. Similarly, how much money to spend to remove radionuclides from drinking water depends heavily on the potential competing financial needs and risk exposures of the community in question. This information is likely to be lodged at the local level. Of course, decisions made directly by the common citizen avoid altogether the risk that elected representatives might not accurately reflect the public's will. This longing for direct democracy often emerges with particular force in the environmental domain because choices are being made about public health and land use, and they evoke strong feelings and a deep distrust of the elite decisionmaking implied by any form of representative government. ${ }^{149}$

The second strand of the public choice argument against federalized environmental programs relates to the distortion of governmental decisions by interest group politics. Some second-generation commentators suggest that the asymmetries of political power between industrial and environmental interests have been exaggerated. ${ }^{150}$ Others indicate that even if there ever were a perceivable gap in interest group access and influence between the federal and state-local levels, it now has been closed with the emergence of many environmental groups operating at

147. The "representativeness" argument discussed here is not wholly distinct from the "diversity" claims outlined above.

148. As Newt Gingrich suggests: "We must replace our centralized, micromanaged, Washington-based bureaucracy with a dramatically decentralized system more appropriate to a continent-wide country. . . . 'Closer is better' should be the rule of thumb." GINGRICH, supra note 1 , at 9.

149. See Soderbaum, supra note 20 (observing that changes in what constitutes harm often emerge from elite analysis with public acceptance and understanding lagging). See generally DANiel A. FArber \& Philip P. Frickey, LAw AND Public ChOICE (1991); THE THEORY OF Public ChOICE II (James M. Buchanan \& Robert D. Tollison eds., 1984); Gary S. Becker, A Theory of Competition Among Pressure Groups for Political Influence, 98 Q.J. EcoN. 371 (1983); William N. Eskridge, Jr., Politics Without Romance: Implications of Public Choice Theory for Statutory Interpretation, 74 VA. L. Rev. 275 (1988); Cass R. Sunstein, Interest Groups in American Public Law, 38 STAN. L. ReV. 29, 32 (1985).

150. See, e.g., James Q. Wilson, The Politics of Regulation 357-94 (1980); Schuck, supra note 122; Richard B. Stewart, Madison's Nightmare, 57 U. CHI. L. REV. 335, 340-42 (1990). 
these levels. ${ }^{151}$ In addition, some second-generation theorists argue that, irrespective of whether environmental interests are underrepresented at the state and local levels, they are overrepresented at the national level. ${ }^{152}$

More dramatically, some commentators argue that Madison's federal architecture, designed to reduce the influence of economic factions, ${ }^{153}$ has given way to a special-interest-dominated federal government in which regulatory powers are often captured by rent-seeking interests or other narrowly focused groups. ${ }^{154}$ In this world of "Madison's nightmare," 155 environmental groups run amok inflicting huge costs on society because their misguided actions play out with magnified significance on the national or international stages. ${ }^{156}$

\section{Moral Arguments}

Second-generation critics flatly reject the morality of forcing subjurisdictions to pay for levels of environmental protection other than those that they choose. They argue that the welfare loss inflicted on the subjurisdiction cannot be justified. Butler and Macey, for example, observe that Stewart's pyramids-of-sacrifice argument depends on "the

151. See Jonathan H. Adler, Environmentalism at the Crossroads: GREen ACTIVISM IN AMERICA (1995).

152. See, e.g., Stewart, Pyramids, supra note 7, at 1218 (discussing the "ratchet" effect); see also Peter H. Schuck, Regulation, Non-Market Values, and the Administrative State: A Comment on Professor Stewart, 92 YALE L.J. 1602, 1609 (1983).

153. See The Federalist No. 10, at 77-78 (James Madison) (Clinton Rossiter ed., 1961).

154. See Stewart, supra note 150, at 340-42; see also ANTHONY Downs, AN ECONOMIC THEORY OF DEMOCRACY (1957); WILsON, supra note 150, at 390-94; Becker, supra note 149, at 371-74; Robert Crandall, Air Pollution, Environmentalists, and the Coal Lobby, in THE POlTICAL ECONOMY OF DeREgulation 84 (Roger Noll \& Bruce Owen eds., 1983); B. Peter Pashigian, Environmental Regulation: Whose Self-Interests Are Being Protected?, 23 ECON. INQUIRY 551-84 (1985).

155. See Stewart, supra note 150 , at 342 ; see also WILLIAM N. ESKRIDGE, JR. \& Philip P. FRICKEY, Legislation 53-61 (1995).

156. See, e.g., Arlie Schardt, Alar Again, L.A. Times, Sept. 7, 1995, at H18 (discussing the Natural Resource Defense Council's ballyhooing over Alar); U.S. Court of Appeals Dismisses Final Appeal on Alar, U.S. NewswIRE, Oct. 3, 1995, National Desk; see also Nathaniel C. Nash, A Humbled Shell is Unsure on Disposal of Atlantic Rig, N.Y. TIMES, June 23, 1995, at D2; Nathaniel C. Nash, Oil Companies Face Boycott Over Sinking of Rig, N.Y. TimEs, June 17, 1995, at A3. Of course, special interest lobbying by industry can have an equally broad impact on national policymaking. See, e.g., Clean Water Act, 33 U.S.C. \& 1257 (1994) (prescribing special treatment of mining wastes); Clean Air Act, 42 U.S.C. § 7412 (1994) (establishing coke-oven preferential treatment); Identification and Listing of Hazardous Waste, 40 C.F.R. $\S 261.4$ (1980) (enumerating the various special interest exclusions from the Resource Conservation and Recovery Act (RCRA) definition of waste); see also ACKERMAN \& HASSLER, supra note 122. 
flawed presumption that it is moral for the federal government to force people to pay for goods they don't want." 157 In brief, this line of thinking defines the relevant political community narrowly and rejects the claims of right by larger governmental entities to dictate environmental standards.

\section{The Insignificance of Externalities and the Nirvana Fallacy}

Many second-generation theorists acknowledge that externalities justify centralized regulation but then proceed with environmental policy prescriptions that implicitly dismiss the problem of interjurisdictional pollution spillovers. ${ }^{158}$ Other second-generation theorists claim not that transboundary externalities do not exist, but rather that governmental reaction is not worth the bother. Although externalities or other market failures may arise, they argue, the capacity of government to regulate effectively is so limited that welfare losses are minimized by letting unregulated market forces operate. ${ }^{159}$ Doubts about the ability of government to design and implement regulatory policies that counteract market failures in a manner that improves social welfare have been called the Nirvana Fallacy. ${ }^{160}$ Adherents to this line of argument reject

157. Henry N. Butler \& Jonathan R. Macey, Externalities and the Matching Principle: The Case for Reallocating Environmental Regulatory Authority, Symposium, Constructing a New Federalism, YAle J. ON Reg. AND YAle L. \& POLY. ReV. (forthcoming 1996).

158. Revesz, for example, acknowledges that interjurisdictional externalities require federal regulation, but then proceeds to offer policy prescriptions as though such externalities do not exist. See Revesz, supra note 1. Others ignore the interstate spillover problem altogether. See, e.g., GINGRICH, supra note 1.

159. Even if a let-the-harms-fall-where-they-may approach maximizes welfare, it violates the protect-property-rights principle of good environmental policy. In fact, in any case in which the costs of regulating (or of vindicating property rights) exceed the value of the harms inflicted by pollution, nonintervention will optimize welfare. This efficiency, however, is achieved at a cost, in terms of equity, as the polluter's welfare gain comes at the expense of the pollutee's rights. Moreover, to the extent we accept a nonintervention principle whenever the costs of regulation exceed the value of the harms to be addressed, we create a serious moral hazard problem. In such a case, polluters have a significant incentive to drive up transaction costs and thereby avoid having to pay compensation for their actions.

160. See Harold Demsetz, Information and Efficiency: Another Viewpoint, 12 J.L. \& ECON. 1, 1 (1969); Maxwell L. Stearns, The Misguided Renaissance of Social Choice, 103 YALE L.J. 1219, 1229 n.33 (1994); see also Butler \& Macey, supra note 157 (discussing the Nirvana Fallacy in the environmental federalism context); Peter S. Menell, Institutional Fantasylands: From Scientific Management to Free Market Environmentalism, 15 HARV. J.L. \& PUB. POLY. 489 (1992). 
not just federal regulation but all regulation. This makes their claims not truly relevant in the centralization versus decentralization debate. ${ }^{161}$

\section{Testing the Second Generation}

This Part examines whether and how decentralized environmental regulation addresses each of the categories of regulatory failure identified in Part I. It seeks to determine: (1) at which governmental level technical issues are likely to be best resolved; (2) whether the structural impediments to achieving least-social-cost environmental policies will be ameliorated or aggravated by a more decentralized regulatory approach; and (3) whether decentralization reduces or worsens the public choice problems associated with environmental policymaking. The analysis is grounded in the realities of environmental problems and regulation because general regulatory theory, on which much of the existing literature relies, often fails to capture the unique features of the ecological domain.

\section{A. Decentralization and Technical Welfare Loss}

Decentralization appears likely to minimize technical transaction costs in some cases, particularly when "on the ground" information matters. But devolution may impede other more truly technical or scientific dimensions of the regulatory process. In many respects, the technical adequacy issue boils down to a question of whether regulatory economies or diseconomies of scale are salient. Generalizations in this regard are not easy to make. Some issues (how to handle toxic waste sites, for example) are local-information intensive; others (determining safe levels of pesticide residues, for example) have only limited dimensions that vary geographically. Perhaps more important, every regulatory decision represents a conglomeration of various policy activities, some of which will benefit from decentralized processes and others of which will be optimized under a centralized regime. The following taxonomy of regulatory activities highlights the difficulty with sweeping presumptions.

161. The Nirvana Fallacy is really about how to regulate. The fact that our current regulatory approaches are inefficient does not mean that no regulation is ultimately the preferred answer. By the same logic, just because today's federal regulation is flawed does not mean that state or local regulation is preferred. As stipulated at the outset, more efficient regulatory tools and strategies are undeniably needed, and such policy advances represent the best response to Nirvana Fallacy concerns. Some Nirvana Fallacy proponents argue that federal regulation is particularly likely to be counterproductive. This suggestion, however, generally collapses into claims about diseconomies of regulatory scale or public choice distortions. 


\section{Problem Identification}

Initial awareness of an ecological or public health issue or harm often emerges from actual observation of physical change. Since many pairs of eyes spread across the land are more likely to see environmental anomalies before a few observers in a centralized location, the diseconomies of scale in problem identification will often be significant. Of course, certain environmental problems are better detected by some eyes than by others. ${ }^{162}$ Complex scientific interactions such as the depletion of the ozone layer by chlorine compounds (CFCs) offers one such example. Problem identification in these cases depends more on technical sophistication than on geographic coverage. Under these conditions, an optimal environmental policy concentrates technical resources in a small number of places to amass sufficient expertise and equipment to track the otherwise invisible problem. ${ }^{163}$ Because of the diversity of environmental harms that governments seek to regulate, a mix of decentralized and centralized, governmental and nongovernmental problem-identification structures is likely to be useful.

\section{Data Collection and Analysis}

Beyond the problem-identification function, technical capacity generally will be weakened by devolution. It makes no sense to ask every state, city, or town to measure the level, size, and type of particulates in its air, determine their connection to respiratory failure and other health problems, identify the safe level of emissions, and design cost-effective policy responses. Data collection and quality control, fate and transport studies, epidemiological and ecological analyses, and risk assessments all represent highly technical activities in which expertise is important and scale economies are significant. In addition, the core variables within these functions do not vary spatially, and thus diversity claims hold little sway. ${ }^{164}$ Absent centralized functions, independent state regu-

162. Not only will some problems require technical skill or equipment to "see," but some patterns and anomalies also can only be perceived on a broad-scale level.

163. Still, total centralization of technical functions in a single entity rarely will make sense. Several competing facilities are likely to spur more rapid scientific advances. Moreover, given the significant degree of uncertainty that pervades environmental decisionmaking, it is important that the prevailing wisdom constantly be challenged and that new perspectives on problems regularly be explored. In this regard, research diversification helps to guard against putting all one's analytic eggs in the wrong basket. Nevertheless, a single research entity might be optimal if a problem is unusually expensive to address (space exploration, for example) such that multiple efforts fragment funding and leave all efforts inadequate to the task.

164. Specifically, while dose responses vary from person to person, animal to animal, and plant to plant, these variations generally do not occur spatially. If 3 in 100 
lators will either duplicate each other's analytic work or engage in timeconsuming and complex negotiations to establish an efficient division of technical labor. The poorer the jurisdiction, moreover, the more likely its regulators will lack basic technical competence. Likewise, the smaller the regulating entity, the more likely it is to suffer from the absence of scientific scale economies. Both of these dimensions of technical failure are recognized as significant obstacles to good regulation in many states. ${ }^{165}$

Despite the prospect of scientific diseconomies of scale, decentralized policy structures still might be worthwhile if multiple approaches to a problem were likely to improve the quality of regulation, the chances of identifying more effective policy tools, or the efficiency of the regulatory process. Fifty state laboratories might come up with the "right" regulatory answer more often than one centralized body. There are two ways in which the states might be thought to have a better chance of getting this right answer than the federal government. The first involves an environmental problem that does not vary much across the country, such as determining the safe level of pesticide residues. In such a case, fifty efforts to establish this variable might be thought more likely to generate a "correct" result, just as fifty throws of a dart are more likely to yield a bullseye than a single toss.

residents of Connecticut will get sick from a certain level of toxic exposure, 3 in 100 Louisianans will as well. There is no need for both Connecticut and Louisiana to establish this same correlation independently. In the rush to highlight the diversity of the human experience, we often seem to forget the unvarying essence of Homo sapiens as a species and, accordingly, the potential for regulatory economies of scale from centralization. This principle is well established in the field of public health. See, e.g., James A. Merchant et al., Byssinosis and Chronic Bronchitis Among Cotton Textile Workers, 76 ANNALS INTERNAL MED. 432, 433 (1972) (showing that cotton dust exposure of American millworkers created the same respiratory disease problems for them as for British cotton millworkers). Of course, in some cases, widespread cultural patterns (smoking and drinking, for example) may sufficiently shape the background levels of risk so that responses will vary across jurisdictions.

165. See Environmental Protection Agency, Report of the Task FORCE TO ENHANCE STATE CAPACITY (1993). Governmental regulatory capacity likely will evolve over time and so too will the optimal mix of regulatory authority between and among levels of government. In fact, devolving environmental responsibilities to the states makes much more sense than it would have 30 years ago insofar as state regulatory capacity has improved dramatically over the intervening years. Similarly, issues evolve in ways that may justify changes over time in the level of government that regulates them. When a problem first emerges, the scientific uncertainties surrounding it may be so predominant that the technical advantages of a centralized governmental response call for federal regulation. As the issue matures and becomes better understood, the salience of the technical economies of scale may recede, which argues for devolution of primary regulatory responsibility to the states and permitting policies more tailored to localized interests. 
Against this hope, however, weigh several countervailing considerations. Will states-as-laboratories really mean more dose-response experimentation? Will the state efforts be serious experimentation or simply guesswork? How many states have the scientific infrastructure, interest, and resources to fund rigorous analytic efforts? Most U.S. states suffer from serious capacity problems in environmental regulation. ${ }^{166}$ Outside the United States, the number of regulating jurisdictions capable of establishing regulatory programs built on even modest scientific and analytic underpinnings is even more limited. The theoretical argument for diversity and decentralization thus runs very quickly into practical capacity constraints in the technical domain. ${ }^{167}$ When complex science is required, states are not the best laboratories; laboratories are the best laboratories.

Another dimension of the states-as-laboratories argument relates to the notion of "egulatory competition" and addresses the question of whether competition among decentralized jurisdictions will improve governmental efficiency. Without denying the need to eliminate slack in governmental operations, there is neither empirical evidence to support nor any theoretical reason to believe that state-level bureaucrats work more efficiently than federal ones because they perceive themselves to be in competition with other states. ${ }^{168}$ Moreover, nongovernmental organizations, able to draw on outside experts and to achieve scale economies by "selling" their ideas in many jurisdictions simultaneously, may be better positioned to provide technical-competition. Environmental groups, in particular, have an incentive to hustle and to seek quick diffusion of their scientific and policy advances because this is how they win credibility and financial support. ${ }^{169}$

166. See EPA, supra note 165, at 5; see also Leslie Fuller Secrest et al., Seep No Evil, AMER. CITY \& COUNTY, May 1993, at 34.

167. The suggestion that decentralization allows for improved political judgments in regulation (that is, better judgements about how much value a localized community would place on a particular policy) may be correct but misses the point. Specifically, the crucial welfare losses with regard to problems like food safety derive not from political miscalculations, but from technical errors in which the regulators misunderstand causal relationships and thus make directionally incorrect policy interventions or miscalculate risks by orders of magnitude. Of course, the technical-inadequacy argument against environmental policy decentralization may not be generalizable as it turns on the particular technical complexity of making good environmental regulatory decisions.

168. To the contrary, it is the author's experience, having visited dozens of state Departments of Environmental Protection as well as numerous federal EPA offices, that, as a general rule, federal officials are better trained, work longer and harder, and have higher productivity than their state counterparts.

169. See Daniel C. Esty, "Why the World Trade Organization Needs NonGovernment Organizations" (paper presented at University of Michigan Conference, Nov. 8, 1996) (on file with author) (making the argument that the best "competition" in 
The second aspect of the states-as-laboratories argument involves environmental problems that are geographically heterogenous, such as how much money to spend cleaning up a toxic waste dump. The "right" answer to such problems depends on locality-specific factors such as on what chemicals are in the waste, whether the waste is migrating off-site, the likelihood that groundwater is affected, the dependence of those in the community on groundwater for drinking, the relative scarcity of land, the likely future use of the site, the wealth of the community in question, and other circumstances. In such cases, on-theground knowledge is of central importance, and the diversity of circumstances is salient. Thus state-by-state or even community-by-community regulation makes sense. Smaller jurisdictions can tailor their regulatory solutions according to the exact, location-specific parameters of a given hazardous waste problem. ${ }^{170}$

Yet even when a problem is largely localized, substantial technical questions, susceptible to economies of scale, remain. How big are the risks posed by the chemicals present? What cleanup technologies are available? How much will various policy alternatives cost? Ultimately, diversity of circumstances argues primarily against regulatory uniformity, not necessarily against centralization - and certainly not against a hybrid policy structure that is centralized in part. ${ }^{171}$

environmental policy comes from environmental groups and businesses). In the environmental realm, nongovernmental entities already make substantial contributions to the data and information bases upon which regulations are based - and in so doing provide considerable intellectual competition to the government. See, e.g., MARK DORFman, Environmental Dividends: CutTing More Chemical Waste (1992) (spelling out "pollution prevention" ideas); PROJECT 88: HARNESSING MARKET ForCES TO PROTECT OUR ENVIRONMENT 30-34 (Robert Stavins ed., 1988) [hereinafter PROJECT 88] (advancing the idea of $\mathrm{SO}_{2}$ emissions-trading to address acid rain, a concept that was adopted in the 1990 Clean Air Act); DAvid J. SAROKIN ET AL., CuTting Chemical Waste: What 29 Organic Chemical Plants are Doing to Cut Chemical Waste (1985).

170. EPA's traditional one-size-fits-all approach to Superfund site remediation represents a classic example of inappropriate centralized regulation. Decentralized information gathering, analysis, and decisionmaking in hazardous waste cleanup cases almost certainly would improve the technical content of the regulatory process.

171. Indeed, many U.S. federal environmental laws, although centrally adopted, permit states to implement more stringent requirements than the national standard or otherwise to tailor the regulatory program to their own needs. See, for example, the varying "non-attainment" standards of the Clean Air Act, 42 U.S.C. $§ \S 7511-13$ (1994). Nevertheless, there appears to be some tendency of centralized regulatory structures to enact more or less uniform standards. See James E. Krier, On the Topology of Uniform Environmental Standards in a Federal System - and Why It Matters, 54 MD. L. REV. 1226, 1228-38 (1995); see also Richard O. Zerbe, Optimal Environmental Jurisdictions, 4 ECOlOGY L.Q. 193, 222 (1974) (noting that local strategies do not require the "jurisdictional choice of local government"). 


\section{Policy Design}

A decentralized regulatory structure offers a mechanism for testing multiple policy alternatives simultaneously with the promise that better approaches will emerge and be adopted broadly. But such gains derive largely from avoiding uniformity and not from avoiding decentralization per se. ${ }^{172}$ Moreover, the administrative advantage of local implementation does not speak to the question of the optimal level of governmental activity in environmental standard setting. Indeed, given economies of scale in technical work and the risk of structural failure from pollution spillovers and strategic behavior unleashing welfare-reducing races toward the bottom or top, the best solution may be nationally adopted, locally implemented, nonuniform standards. Such a solution entails optimizing both the scale of standards and the scale of institutions. ${ }^{173}$

In some circumstances uniform standards may be welfare enhancing. ${ }^{174}$ When environmental regulations are focused on products (as opposed to production processes), harmonization across jurisdictions can create important economies of scale for the businesses selling these products $^{175}$ and for the states administering environmental controls. For example, national automobile tailpipe standards allow Detroit to produce vehicles from a single production line, thus lowering both average and marginal costs. ${ }^{176}$ National standards also spare the fifty states the

172. See Zerbe, supra note 171 , at 215-21 (discussing losses from uniformity).

173. See E-mail from Jonathan Wiener, Professor, Duke Law School, to Daniel C. Esty, Professor, Yale Law School (Aug. 27, 1996).

174. See supra note 47 (discussing optimal specificity). As noted in Part I, the tailoring of regulations to smaller and smaller subgroups achieves welfare gains by matching policies with local values, but this comes at the cost of increased administrative burden. There is a further question about what level of government is best positioned to determine the optimal level of regulatory activity for any specific problem, particularly in light of the fact that answering optimal-specificity questions consumes resources and involves deliberation costs. The economies of scale in analytic methods argue for having the metaquestion of optimal scale answered nationally. See Wiener, supra note 173.

175. For example, some champions of decentralization also will be strong advocates of federal regulation when the scale economies of the national market are at issue. In fact, 91 preemption statutes, substituting uniform federal standards for diverse state regulations, were enacted into law during the Reagan era. See SUSAN ROSEackérman, Rethinking the Progressive Agenda: The Reform of the AMERICAN REgUlatory STATE 162 (1992).

176. To this day, U.S. automakers are striving to maintain a commitment to a "49state car" in the face of a thrust from a number of Northeastern states to set tailpipe standards that match the more stringent California requirements. See Jake Brown, EPA Proposes 49-State-Car Option, But Automakers, States Continue Talks, BNA, Oct. 2, 1995, available in 1995 WL, BNA-SED Database; Matthew L. Wald, E.P.A. Backs Plan to Allow Cleaner Cars in Most States, N.Y. Times, Sept. 28, 1995, at A16; Adrian Walker, World Considers Deal on Phase-In of Electric Cars, Boston GLOBE, July 31, 1995, at 13. 
expense of trying to determine and enforce their own standards. ${ }^{177}$

Uniformity with regard to production-process pollution controls also may be beneficial in some instances: following common approaches to a common problem may be particularly welfare enhancing if "network" effects are significant. ${ }^{178}$ Even if the pollution policies of one jurisdiction are not perfectly aligned with the needs of another jurisdiction, the latter rationally might adopt the former's standards to avoid the considerable expense of creating a regulatory program from scratch with all of the attendant development costs vis-à-vis data, risk analysis, policy mechanisms, control technologies, training, and enforcement. ${ }^{179}$ These costs will be especially large for small jurisdictions that will have difficulty persuading producers of pollution-control goods and services to tailor products to their jurisdiction's unique specifications. Network effects may be particularly important in the environmental realm because of the technical complexity of the requisite policy analysis and design functions and the relative incapacity of many jurisdictions singularly to bear the costs associated with that complexity.

Uniform standards also may stimulate innovation in pollution-control technologies. Notably, the larger the market, the bigger the potential payoff to investors and the more likely it is that innovators and entrepreneurs will be able to acquire venture capital. Fragmented markets are unattractive to potential investors. ${ }^{180}$ In fact, the relatively decentralized environmental regulatory structure of the United States has already

177. See Rose-ACKERMAN, supra note 175 , at 165 ; Elliott et al., supra note 69 ; Mashaw \& Rose-Ackerman, supra note 111, at 113-34; Susan Rose-Ackerman, Environmental Policy and Federal Structure: A Comparison of the United States and Germany, 47 VAND. L. REV. 1587, 1592 (1994).

178. See Bratton \& McCahery, supra note 118, at 24-26; Philip Dybrig \& Chester Spatt, Adoption Externalities As Public Goods, 20 J. PUB. ECON. 231 (1983); Michael L. Katz \& Carl Shapiro, Network Externalities, Competition, and Compatibility, 75 AM. ECON. Rev. 424 (1985); Michael Klausner, Corporations, Corporate Law, and Networks of Contracts, 81 VA. L. REV. 757 (1995) (spelling out network benefits to common contract terms).

179. The classic example of network effects is the QWERTY typewriter keyboard. The layout of the keys is demonstrably nonoptimal, but changing the standard has proven to be impossible because huge investments in training and knowledge would be lost by a shift to another keyboard layout. See Paul A. David, Clio and the Economics of QWERTY, 97 AM. ECON. Assoc. PAPERS \& PROC. 332 (1985); Steve Lohr, Business Often Goes to the Swift, Not the Best, N.Y. TIMES, Aug. 6, 1995, § 4, at 3; see also Klausner, supra note 178, at 792-808 (discussing network effects in legal interpretations in the corporate contract context).

180. As a general partner in a California venture capitalist firm testified in a written statement presented at a U.S. Senate hearing, the lack of centralization in U.S. environmental regulation "penalizes innovation and repels capital." Hearings on S. 978 Before the Senate Comm. on Environment and Public Works, 103d Cong. 79 (1993) (statement of Dag Syrrist). The statement went on to decry the current regulatory struc- 
proven to be a serious obstacle to entrepreneurs seeking venture capital. ${ }^{181}$ Further devolution promises to exacerbate the difficulty of achieving scale economies sufficient to promote innovation, bring new technologies to bear on U.S. environmental problems, and lower the cost of environmental protection. . $^{182}$

Multiple jurisdictions could settle upon common policy approaches that would allow the scale economies identified above to be achieved without centralized regulation. Indeed, Alan Sykes argues that consumer demand and the workings of the market will yield optimal compatibility in standards across jurisdictions. ${ }^{183}$ But while such market-driven harmonization has emerged in some realms (VCRs and computers, for example), the coordination record in the environmental domain appears far more spotty. ${ }^{184}$

Centralized environmental regulation, moreover, need not mandate fixed uniform standards. One important alternative is minimum standards that provide a limited common goal, ensuring that all parties meet a basic level of environmental protection. For some jurisdictions, baseline standards may be the most appropriate endpoint for their environmental programs given their level of economic development and other specific circumstances. In other jurisdictions, more stringent standards

ture, which "effectively partitioned a national market into several hundred regional and local markets each with unique permitting requirements." Id. at 81 .

181. Far less venture capital flows into environmental goods and services companies than into other economic sectors of comparable size. See Internal Memorandum from the Executive Office of the President, Office of Science and Technology Policy, Environment Division (1995) (on file with author).

182. As Howard Kunreuther has reminded me, a standardized regulatory structure also facilitates development of the insurance market - which could be quite useful as a policy response to environmental risks.

183. See Alan Sykes, Product Standards for Internationally InteGRATED GOODS MARKETS (1995) (focusing on computer software and other products, not processes such as environmental production standards); see also DAvID VoGEL, TRADING UP 189-91 (1995) (observing that in product markets, environmental standards are often harmonized upwards).

184. The Organization for Economic and Community Development (OECD) has had some success in getting its member countries to coordinate their chemical testing protocols. But efforts to harmonize pesticide regulation, basic environmental data collection, and other aspects of environmental regulation have proven far less successful, even when the promise of scale economies are substantial. See OECD, THE OECD Chemicals Programme (1993). Whether the actual environmental standards should be uniform depends on the intersection of a number of factors including: (1) how much the problem at hand varies spatially (which will be affected by the nature of the problem, geography, climate, weather, and other factors); (2) how heterogeneous the affected population is in its values, including wealth (which shapes preferred tradeoffs between income and environmental protection), risk preferences, and other variables; and (3) how the size of welfare gains from scale economies in production and regulatory administration compare with potential welfare losses from diminished diversity. 
will be appropriate given higher levels of available resources and greater public demand for environmental protection. Under a system of minimum standards, governments remain free to adopt a higher level of environmental protection. ${ }^{185}$

Many of the benefits of a decentralized regulatory structure also could be achieved by using more flexible regulatory tools. ${ }^{186}$ Rather than mandating specific uniform control technologies, pollution standards can be performance-based - setting, for instance, an allowable effluent limit per hour or day. ${ }^{187}$ While the pollution-control goal is centrally determined, the individual factory decides how to meet the goal. Even greater flexibility and efficiency can be achieved through ambient standards that allow the regulatory system to reflect background pollution levels and differences in physical conditions. Thus, for example, companies operating in open windy areas may be allowed to emit more than those operating in geographically enclosed areas. ${ }^{188}$

Further flexibility and efficiency can be built into both effluent and ambient standards through a system of differentiated requirements. By varying the goals or the timetables for reaching goals for diverse areas, differences in circumstances can be accommodated within centrally devised regulatory programs. For example, particularly challenging air pollution problems, such as those facing Los Angeles, can be given special consideration within a national clean air program. In fact, the Clean

185. The Treaty on European Union (Maastricht Treaty) art. 130T provides for such a scheme. See Damien Geradin, Trade and Environmental Protection: Community Harmonization and National Environmental Standards, 13 Y.B. EUR. L. 151, 178-86 (1994).

186. In fact, much of the welfare loss in environmental policy today appears to come neither from diseconomies of regulatory scale nor the related problem of standards being set at too high a level of aggregation and hence overriding the particularized circumstances and values of smaller scale communities. Rather, the loss comes from the weakness of the scientific-technical bases for regulation and the vagaries of the existing set of environmental tools and strategies. See, e.g., Revesz, supra note 9.

187. Many Clean Water Act standards take this form. See Clean Water Act $\S \S 301-304,33$ U.S.C. $\S \S 1311-1314$ (1994). Unfortunately, the translation of these effluent standards into specific obligations of dischargers shifts the regulatory focus from performance standards to various "Best Available Technology" requirements. See Clean Water Act $\S \S 301$ (b)(1), 306, 33 U.S.C. $\S \S 1311(b)(1), 1316$ (1994).

188. The nonattainment and the National Ambient Air Quality Standards (NAAQS) provisions for criteria air pollutants of the Clean Air Act could work in this fashion, setting the pollution control goal centrally, but allowing local officials to determine how to meet the standards through State Implementation Plans (SIPs). See Clean Air Act Amendment of $1970 \S 109,42$ U.S.C. $\S 7409$ (1994). But the promise of national ambient standards has not been achieved. See John P. Dwyer, The Practice of Federalism Under the Clean Air Act, 54 MD. L. REv. 1183, 1198 (1995); William F. Pederson, Why the Clean Air Act Works Badly, 129 U. PA. L. REV. 1059, 1071-93 (1981). 
Air Act seeks to differentiate among extreme, severe, serious, and moderate "nonattainment" areas, giving those with greater problems up to seventeen extra years to come into compliance with the national goals. ${ }^{189}$

The use of economic-incentive-based regulatory tools can further loosen the grip of federal regulators and give broad scope to private actors to determine how best to meet environmental goals. The use of effluent fees, pollution trading systems, and ecolabels or other public information strategies permit considerable differentiation among locales and even among individuals with different preferences within the same locale. In addition, fees or emissions allocations can be adjusted to reflect particular circumstances. Moreover, the trading that occurs explicitly under systems like the acid rain control program of the 1990 Clean Air Act and implicitly in any pollution-fee-based regulatory regime allows for efficient market-determined pollution-control programs, thereby maximizing the benefits from any dollar invested in pollutionprevention or -abatement programs and minimizing the welfare losses imposed by the regulatory constraints. ${ }^{190}$

Ultimately, diseconomies of scale and diversity arguments do not argue for state regulation but simply for flexible and efficiency-minded regulatory tools and strategies. Likewise, the promise of technical economies of scale does not necessarily argue for a centralized environmental regime in any strong sense. Specifically, one could envision an environmental policy structure that obtained scale economies in the technical aspect of the regulatory process without centralizing other dimensions of the environmental control system. In fact, the optimal policy response to the problems of technical inadequacy is probably the creation of a National Institute for the Environment (NIE). An NIE, like the National Institutes of Health (NIH), would serve as a centralized data gathering and analysis mechanism. It would offer scientific support to regulating jurisdictions that would use the data and information provided to set their own standards. An NIE also could develop model legislation as one way of consolidating diverse information into a form that would be useful to regulating jurisdictions. Such a mechanism

189. See, for example, ozone (smog) requirements under the 1990 Clean Air Act Amendments, Pub. L. No. 101-549, § 181(a)(2), 104 Stat. 2423 (codified at 42 U.S.C. $\S$ 7511(a)(2)).

190. See Project 88, supra note 169; Daniel J. Dudek et al., Technology-Based Approaches versus Market-Based Approaches, in GREENING INTERNATIONAL LAW 182 (Phillipe Sands ed., 1994); Robert W. Hahn \& Robert N. Stavins, Market-Based Environmental Regulation: A New Era From An Old Idea, 18 Ecology L.Q. 1 (1991); Richard B. Stewart, Controlling Environmental Risks Through Economic Incentives, 13 Colum. J. ENVTL. L. 153 (1988). 
would go a considerable distance toward addressing the capacity problem that historically has plagued state-based environmental regulation. ${ }^{191}$

Decentralization generally fails to minimize technical environmental regulatory costs. While diseconomies exist in a few parts of the regulatory process, most aspects of environmental research and analysis show significant economies of scale. The strength of diversity arguments thus must be seen essentially not as technical, but either as structural (smaller jurisdictions empowered to establish their own standards will reduce the internalities associated with uniform standards, thereby increasing social welfare) or as related to public choice (decentralized political processes are more likely to track localized citizen preferences). In either case, to achieve the goal of minimizing technical welfare loss, technical and scientific responsibilities should not be devolved to state governments. ${ }^{192}$

\section{Implementation, Enforcement, and Policy Evaluation}

The implementation and enforcement of environmental policy is done best on a relatively decentralized basis to ensure that the regulating entity is aware of local circumstances and is accessible to the regulated community. There is, however, an important caveat to this general principle: enforcement against large companies may be accomplished better by the federal government. At the very least, the need to protect states from especially powerful economic and political forces argues for a system of federal oversight of state environmental programs. ${ }^{193}$ More-

191. It is ironic that the Congress, which is pushing regulatory devolution so strongly, is not advancing efforts to address the state capacity problem. Efforts to create a Bureau of Environmental Statistics have failed and the Office of Technology Assessment was abolished. See House Expected to Act on Rescissions Bill; Senate to Continue on EPA Cabinet Status, BNA, Apr. 26, 1993, available in 1993 WL, BNA-BWI Database; Greg Pierce, Study Advises Devolving EPA Powers, WASH. TIMES, Apr. 12, 1995, at A9; Senate Bill would Elevate EPA to Cabinet, BNA, May 20, 1994, available in 1994 WL, BNA-BWI Database. Moreover, data-gathering efforts such as the National Biological Survey have faced sharp budget cuts. See Tom Kenworthy, By Any Name, Biological Service Appears To Be Endangered Species, WASH. POST, June 27, 1995 , at A15.

192. By extension, the technical advantages of centralization argue for increased international scientific and analytic cooperation. Why, for example, does the United States spend $\$ 100$ million per year testing pesticides, some of which already have undergone exhaustive analysis in Europe or Japan? Common testing protocols and data exchange would allow the United States to incorporate risk analyses done elsewhere, thereby improving the speed and cutting the cost of U.S. regulation.

193. Many state officials privately observe that the threat of unleashing the "gorilla in the closet" - the federal EPA - makes it much easier for them to do their job. See National Clean Air Coalition Press Conference Concerning the President's Clean 
over, when problems are transboundary in scope, and especially when the jurisdictions are separate countries, decentralized enforcement breaks down entirely. ${ }^{194}$

The evaluation and refinement of environmental policy strategies benefits from comparative analysis and therefore from some degree of centralization. Nevertheless, because each subjurisdiction has an incentive to cooperate in carrying out evaluation procedures and in sharpening its own programs, there is no need for rigid or coerced centralization of policy evaluation activities.

\section{B. Decentralization and Structural Welfare Loss}

It is well established that internalities should be avoided, externalities should be internalized, and efficiency in the provision of a collective good requires the jurisdiction of the government that provides it to match the boundaries of the good. ${ }^{195}$ There seems, however, to be some confusion over the type and pervasiveness of jurisdictional mismatches in the environmental realm. ${ }^{196}$ To determine what level of government

Air Proposals, Federal News Service, June 12, 1989, available in LEXIS, News Library, FEDNEW File; see also David R. Hedas, Enforcement of Environmental Law in a Triangular Federal System: Can Three Not Be a Crowd?, 54 MD. L. REV. 1552, 1574 (1995).

194. See, e.g., Daniel Bodansky, Customary (And Not So Customary) International Environmental Law, 3 IND. J. Global LEGAL STUD. 105, 110-11 (1995) (observing that uncontrolled transboundary pollution is the rule rather than the exception); Edith Brown Weiss \& Harold K. Jacobson, Why Do States Comply With International Agreements?, 1 HumaN Dimensions Q. 1, 4 (1996) (reporting on a study finding that internationally decentralization does not improve compliance); David Wirth, Climate Chaos, 74 FOREIGN POLY. 3 (1989); see also DunCAN BRACK, INTERNATIONAL Trade AND THE MONTREAL PROTOCOL 99-114 (1996) (discussing widespread noncompliance with the Protocol and illegal trade in CFCs). See generally LAKSHMAN D. GURUSWAMY ET AL., INTERNATIONAL ENVIRONMENTAL LAW AND WORLD ORDER 31-43 (1994).

195. See Olson, supra note 40 , at 42-43; see also BAUMOL \& OATES, supra note 8 , at 287 (arguing that jurisdictions need to be sufficiently large to encompass the benefits and costs associated with the pollutant and its control); Butler \& Macey, supra note 157 (advancing a Matching Principle).

196. Although some commentators suggest otherwise, concern about interstate externalities has provided a driving force for the adoption of national environmental laws in the United States. See H.R. REP. No. 94-1175 (1976); H.R. REP. No. 95-294 (1977) (discussing Clean Air Act Amendments of 1977). But see Revesz, supra note 1, at 1212 (arguing that "interstate externalities explain only isolated parts of the federal environmental statutes"). Concern about transboundary externalities also represents the cornerstone of centralized environmental regulation in the European Union. See, e.g., van den Bergh et al., supra note 118. A related question is how well federal laws address interstate externality issues. That many federal laws do not perform this task particularly well is undeniable; however, this inadequacy is more an argument for federal legislative reform than for broad policy devolution. 
should set environmental policy to minimize structural welfare losses, the critical variables are the prevalence and magnitude of externalities and internalities.

\section{Physical Externalities}

Given the widespread theoretical acceptance of externalities as a rationale for centralized environmental regulation, policy conclusions in favor of decentralization depend on an implicit assumption that interstate externalities are not significant. Such a dismissive attitude toward pollution externalities does not, however, square with environmental reality.

a. Empirical evidence. While a few environmental harms (some waste problems, for example) are geographically localized, many forms of pollution (surface water contamination and most air pollutants, for example) spread across the land. Because state boundaries often do not fully encompass airsheds and watersheds, interjurisdictional externalities arise. Given a fixed extent of pollution, it is axiomatic that decentralization will create more borders and therefore more transboundary spillovers. Moreover, advances in environmental science over the last two decades have resulted in the discovery of a number of previously unrecognized externalities. These include, most notably, global concerns such as ozone layer depletion and possible climate change due to the accumulation of greenhouse gases. ${ }^{197}$ In addition, recent scientific work has broadened the acknowledged geographic scope of the impact of previously identified problems. For example, DDT - long banned in the United States and Canada - has been discovered in the Great Lakes, demonstrating, scientists believe, that high-level winds can transport airborne chemicals thousands of miles, in this case from Mexico. ${ }^{198}$ Similarly, recent studies have discovered significant transboundary spillovers of $\mathrm{SO}_{2}$ and acid rain, heavy metals, and bioaccumulative toxics. ${ }^{199} \mathrm{We}$ will probably continue to find additional linkages and elements of inter-

197. See Adrienne C. Brooks, NASA Identifies Cause of Ozone Depletion, SCIENCE NewS, Dec. 24, 1994; Richard A. Kerr, Antarctic Ozone Hole Fails to Recover, SCIENCE, Oct. 14, 1994, at 422; Richard A. Kerr, Studies Say - Tentatively - That Greenhouse Warming is Here, SCIENCE, June 15, 1995, at 1567; Richard Monastersy, Dusting the Climate for Fingerprints: Has the Greenhouse Warming Arrived? Will We Ever Know, SCIENCE News, June 10, 1995, at 362.

198. See, e.g., R.A. Rappaport et al., "New" DDT Inputs to North America: Atmospheric Deposition, 14 CHEMOSPHERE 1167 (1985); Andrew Lawler, NASA Mission Gets Down to Earth, SCIENCE, Sept. 1, 1995, at 1208.

199. See, e.g., William F. Fitzgerald, Mercury as a Global Pollutant, WORLD \& I (Oct. 1993) at 192; Carrie Levine, Arctic as Polluted as Europe 100 Years Ago Study, Reuters North American Wire, Mar. 3, 1996, available in LEXIS, News Library, 
dependence and thus additional externality-based reasons to consider centralized environmental regulation.

b. What Form of Centralization? The presence of a transboundary harm demands some form of overarching governmental action across the scope of the harm. Lack of a mechanism to facilitate collective action among jurisdictions whose fates are ecologically linked leads to a tragedy-of-the-commons dynamic that promises market failure, allocative inefficiency, welfare loss, and infringements on property rights. At the very least, the jurisdictions sharing an environmental resource or problem must establish a process for clarifying the scope of the property rights in question as well as rules and procedures for allowing these rights to be traded (and, if necessary, vindicated at law) at low cost. Such a structure requires some degree of centralization. Thus, the question is not whether to have centralized regulation, but rather what kind of centralization to pursue.

As discussed in Part $I,{ }^{200}$ how far one moves from cooperative policies toward more full-blown centralization is simply a matter of degree. If environmental property rights are clear and mechanisms for trading and vindicating these rights are available at a reasonable cost, centralized regulation is not needed. But often these conditions are not met. ${ }^{201}$ Beyond this theory, empirical observation supports the conclusion that collaboration among decentralized jurisdictions often yields unsatisfactory results in response to externalities. Even among the U.S. states, collaboration in response to interstate pollution is minimal. ${ }^{202} \mathrm{Be}$ yond federal mandates, states take little account of the harms that their industries cause to downriver or downwind jurisdictions. ${ }^{203}$ Internation-

Txtnws File (finding mercury, PCPs, and insecticides in Arctic fish); R.A. Rappaport et al., supra note 198.

200. See supra text accompanying notes 57-62.

201. As noted in Part I, every time we move from a single jurisdiction (with a fully centralized regulatory regime) to a multijurisdictional world, we reopen the "why regulation" question.

202. The struggles of the Ozone Transport Assessment Group demonstrate this fact. See Anthony Jewell, Utilities Group Says Federal Ozone Rules May Be Unfair to State, CourIER-J. (Louisville, Ky), Feb. 7, 1996, at 2B; Proposed Ozone Transport Plan Would Fall Hard on Utilities, ENERGY REP., Feb. 26, 1996, available in WeStlaw, 1996 WL 8375588; Doug Sword, Midwest Fights Dirty Image, Blame for Pollution Called Unfair, Plain DeAler (Cleveland, Ohio), Mar. 17, 1996, at 17A.

203. See GERRARD, supra note 73, at 98 (noting prevalence of locally undesirable land uses (LULUs) on state boundaries); Richard E. Ayres, Enforcement of Air Pollution Controls on Stationary Sources Under the Clean Air Act Amendments of 1970, 4 ECOLOGY L.Q. 441, 452-53 (1975); Revesz, supra note 186, at 16 (noting that states encourage tall stacks, pushing pollution downwind). Maine's independent governor Angus King recently demanded that the EPA take action to stop pollution from other 
ally, efforts to internalize pollution externalities are even more crude. ${ }^{204}$ Countries often assert their "sovereignty" over their resources and environmental policy as though this mantra provides immunity from responsibility for transboundary pollution spillovers. ${ }^{205}$ Ultimately, though the difficulty of coordinating across jurisdictions - which is undoubtedly greater internationally than among national subjurisdictions speaks to the question of what sort of regulatory regime will be possible; it does not change the need for overarching governmental intervention to avoid market failure and property rights infringements.

\section{Economic Externalities: The Race to the Bottom}

The prisoner's dilemma dynamic inherent in circumstances of economic interdependence and the resulting risk of economic externalities and welfare loss long have been understood. To respond to noncooperative "beggar-thy-neighbor" tariff and currency policies that led to global economic chaos in the 1930s, the architects of the postWorld War II international order recognized the need to erect an elaborate worldwide regulatory regime for international trade. ${ }^{206}$ The prospect

states blowing into Maine. See John Milne, Maine Blames Massachusetts, Others For Polluting Air, Boston GloBe, Aug. 2, 1995, at 20.

204. See generally Bodansky, supra note 194. But see INSTITUTIONS FOR THE EARTH: SOURCES OF EFFective INTERnAtional ENVIRONMENTAL Protection (Peter M. Haas et al. eds, 1993) (identifying some examples of international cooperation). For specific case reports, see Christopher Bobinski, Survey of the Baltic Basin States, Fin. TIMES, Dec. 16, 1992, at 14 (discussing northern Europe acid rain problems); Jane Shaw, Debate Over Acid Rain Will Intensify in 1981, CHEM. ENGINEERING, Feb. 1981, at 435. More recently, Japan has become alarmed at China's pollution spillovers across the Sea of Japan. See Geoffrey Murray, Massive Environmental Cleanup Urged in China, Japan Economic Newswire Plus, Nov. 12, 1994, available in DIALOG, File No. 612.

205. There is, in fact, no sovereign right to pollute. On the contrary, both Principle 21 of the Stockholm Declaration of 1972 and Principle 2 of the Rio Declaration of 1992 establish the opposite principle, that states have a "responsibility to ensure that activities within their jurisdiction or control do not cause damage to the environment or other States or areas beyond the limits of national jurisdiction." Declaration on the Human Environment: Report of the United Nations Conference on the Human Environment, supra note 42, at 10; Rio Declaration on Environment and Development, supra note 42, at 2. Thus, it is the victims of transboundary pollution that suffer an affront to sovereignty. But see Marc Pallemaerst, International Environmental Law from Stockholm to Rio: Back to the Future?, in GreEning InTERnational LAw 1, 5 (Phillippe Sands ed., 1993) (noting that the responsibility for spillovers is juxtaposed with a "sovereign right" to exploit one's own resources).

206. For a complete history of the GATT, see JOHN H. JACKSON, WORLD TRADE AND THE LAW OF GATT (1969). See also ESTY, supra note 52, ch. 4. For a further history of other parts of the "Bretton Woods" regime, see ROBERT SOLOMON, THE INTERNATIONAL MONETARY SYSTEM, 1945-1976, at 10, 13, 31-32, 211-13 (1977). Similar "commons" problems in the context of governmental redistributive 
of economic spillovers in the environmental domain entails a similar situation: horizontally arrayed jurisdictions competing for economic advantage through beggar-thy-neighbor environmental policies.

Fears of a welfare-reducing race to the bottom represent one of the central underpinnings of federal environmental regulation in the United States. ${ }^{207}$ Competitiveness concerns also have been at the heart of the debate about the appropriate scale of environmental regulation in the context of liberalized international trade. ${ }^{208}$ Yet it has become a key tenet of second-generation thinking that such fears are unjustified and even counterproductive from a social welfare perspective. ${ }^{209}$

There is little controversy about the dynamic that underlies such fears. Whenever a jurisdiction's industries are in competition with companies from other locales that have lower environmental compliance costs, governmental officials face pressures either to reduce the regulatory burden or to risk lost sales for their industries, reduced future investment, job displacement, and even industry migration. ${ }^{210}$ The question is whether this strategic dynamic enhances or reduces social welfare. Second-generation theorists refer to these pressures as "regula-

functions also have been identified. See David L. Shapiro, Federalism 46 (1995) (arguing that redistributive governmental activities must be centralized); see also PETERSON, supra note 113, at 76-77.

207. See supra note 66.

208. See ESTY, supra note 52, at 155-80; Stewart, supra note 64; see also Owen Lomas, Environmental Protection, Economic Conflict and the European Community, 33 MCGill L.J. 506 (1988); Max Baucus, Protecting the Global Commons: The Nexus Between Trade and Environmental Policy (Oct. 30, 1991) (address before the Institute for International Economics).

209. Many economists speak out of both sides of their mouths on this issue. On the one hand, they recite the economic orthodoxy that finds no empirical evidence of a race to the bottom. See ROBERT REPETTO, JOBS, COMPETITIVENESS, AND ENVIRONMENTAl Regulation: What ARE The ReAl Issues? 9 (1995); Jaffe et al., supra note 134; Kalt, supra note 134; Low \& Yeats, supra note 134 . On the other hand, they endorse the basic theory of comparative advantage, which suggests that we should expect (and desire) pollution-intensive operations to move to jurisdictions with lower environmental standards. See, e.g., The Freedom To Be Dirtier Than the Rest, EconoMIST, May 30, 1992, at 7 (explaining the economic logic for having more polluting industries located in developing countries); Let Them Eat Pollution, ECONOMIST, Feb. 8, 1992, at 66 (discussing Harvard economist and now Treasury Deputy Secretary Larry Summers's infamous World Bank memo advocating migration of dirty industries to developing countries).

210. See Richard B. Stewart, Environmental Regulation and International Competitiveness, 102 YALE L.J. 2039, 2041, 2084-86, 2098 (1993); Kym Anderson, Environmental Standards and International Trade 7 (April 1996) (unpublished paper prepared for the World Bank's Annual Conference on Development Economics, Washington, D.C., Apr. 25-26, 1996) (maintaining that one country's environmental policy choice is not independent of the choices of other countries). But see REPETTO, supra note 209 (arguing that competitiveness effects are not serious). 
tory competition" and believe that the results are presumptively efficient and welfare optimizing. ${ }^{211}$ Revesz not only proffers the welfareenhancing promise of the regulatory competition dynamic but also disparages the logic of the race to the bottom. He declares that race-to-thebottom arguments in the environmental area have been made "with essentially no theoretical foundation" and that interstate regulatory competition should be seen as "presumptively beneficial."212 Race-to-thebottom theorists obviously disagree on both counts.

a. Regulatory Competition Versus the Race to the Bottom. The two theories can be distinguished by their assumptions. If the environmental policy process resembles a prisoner's dilemma, then suboptimal results may ensue, ${ }^{213}$ but if the market for location rights is relatively competitive and the environmental standard-setting process parallels pricing under perfect competition, then there is no reason to fear a race to the bottom. ${ }^{214}$ Standards may be reduced, but governments will not pursue suboptimal environmental policies just to obtain economic gains. ${ }^{215}$ Thus, the central question is: Does the "market" for environmental policymaking look more like perfect competition, in which efficiency gains can be anticipated from the competitive forces unleashed, or imperfect competition, in which market failures will reduce welfare?

Revesz acknowledges distinctions between the market for location rights and a widget market, but he finds the differences unimportant. ${ }^{217}$ For him, as for other regulatory competition theorists, the law is a

211. See Revesz, supra note 1, at 1253. Even Stewart, the original proponent of federal regulation to respond to the race to the bottom, now seems to believe that stateagainst-state regulatory competition will often lead to better results. See Stewart, supra note 64 , at 1341 n.36.

212. Revesz, supra note 1 , at $1244,1253$.

213. Revesz himself demonstrates this logic. See Revesz, supra note 1, at 122933; see also Alvin K. Klevorick, Reflections on the Race to the Bottom, in FAIR TRADE AND HARMONIZATION, supra note 132, at 459.

214. See Revesz, supra note 1, at 1233-35.

215. Suboptimality might, moreover, arise in the form of standards that are "too high." Indeed, in some industries, locational decisions may turn on employee amenities such as a clean environment, in which case governments might "overspend" to attract the facility, producing a "race to the top." See EDWIN S. MILLS \& BRUCE W. HAMILTON, URBAN ECONOMICS 38 (4th ed. 1989) (observing that higher amenities may allow a company to pay lower wages).

216. As Klevorick notes, if the prisoner's dilemma is an accurate picture of competition among governments, then those who argue that there is a race to the bottom are on firm ground, but if the regulatory market is not subject to failure, then interjurisdictional competition will enhance and not harm welfare. See Klevorick, supra note 213, at 461.

217. See Revesz, supra note 1 , at 1234-35. 
"product," like any other. ${ }^{218}$ Just as price competition disciplines companies in the private marketplace, regulatory competition forces governments to compete for citizens and companies under conditions that closely resemble competition among producers of other goods. ${ }^{219}$ Thus, Revesz asks rhetorically: "If one believes that competition among sellers of widgets is socially desirable, why is competition among sellers of location rights socially undesirable?" 220

The answer to this question is straightforward: states act strategically. ${ }^{221}$ Competition in the regulatory market does not work like product competition. Unlike firms in perfect competition, states in their regulatory mode are not pure price takers. ${ }^{222}$ They cannot ignore the fact that a slight reduction in environmental standards (the price of their location rights) might bring economic welfare gains in excess of any

218. See Bratton \& McCahery, supra note 118 , at 1 ("The law as a product analogy invites a prediction that the governments producing law will compete for customers, rent-producing citizens, firms, and transactions - if given the freedom to do so."). See generally Roberta Romano, Law as a Product: Some Pieces of the Incorporation Puzzle, 1 J.L. ECON. \& ORG. 225 (1985).

219. When governments act in other ways, for example, in their redistributive role, we know that races will be triggered and that such functions must be done centrally. See, e.g., PETERSON, supra note 113, at 76-77 ("The more a local community engages in redistribution, the more the marginal benefit/tax ratio for the average taxpayer declines, and the more the local economy suffers."). Thus, to the extent that environmental policies are redistributive, they must be centralized. "Environmental justice" goals, for example, should be pursued on a national basis. Similarly, addressing certain indivisibly national environmental problems (cleaning up Department of Energy weapons factories or other defense-related contamination, for example) is also redistributive, and requires a centralized regime at least to raise the necessary funds if not to manage the details of each cleanup effort.

220. Revesz, supra note 1 , at 1234 . Revesz assumes that citizens are immobile. In his analogy to the widget market, he assumes that firms are the only consumers of location rights.

221. See Barrett, Strategy and Environment, supra note 115 . For evidence that states (and Indian tribes) in fact do seek to attract industry on the basis of their relatively lax environmental standards, see GERRARD, supra note 73, at 135-38; High Desert Regional Economic Development Authority, Advertisement, ExPANSION MGMT., Nov.-Dec. 1995, at 16 (promising "flexible air standards"); Healdsburg Redevelopment Agency, Advertisement, CAL. STRATEgies, Autumn 1995, at 22 (offering "environmental problem-solving"); see also DAN McGovern, THE CAMPO INDIAN LANDFILL WAR (1995) (discussing waste companies' interest in low-standard Indian reservations as the site for new facilities).

222. Revesz elides this critical point. Indeed, while much of the early part of his article, see Revesz, supra note 1, at 1213-18, focuses on the environmental policy challenge as a prisoner's dilemma and implies strategic behavior and imperfect competition, he then shifts abruptly to a discussion of regulatory competition, see id. at 1234-35, which implies a model of perfect competition and assumes away the problem of strategic behavior. See Brian Langille, "A Day at the Races": A Reply to Professor Revesz on the Race to the Bottom (June 15, 1994) (unpublished manuscript, on file with the Michigan Law Review). 
losses from the resulting environmental degradation. In contrast, perfectly competitive firms face no such incentive because they can sell any quantity that they choose at the market-clearing price. ${ }^{223}$ Moreover, they will lose, not gain, by lowering their price.

Differences between the markets for widgets and location rights need not always produce a race to the bottom. ${ }^{224}$ Yet there are a host of factors suggesting that the market for environmental-policy-driven location rights is relatively imperfect and thus that untrammeled regulatory competition produces suboptimal outcomes. These factors are not universally or uniformly present, but their frequency in the real world is such that the benefits of regulatory competition cannot be presumed. ${ }^{225}$

First, environmental regulation operates in a realm where quantitative welfare comparisons are difficult. The "hard" variables in any cost-benefit calculus dwarf the "soft." Thus, while the logic of regulatory competition in the tax or corporate-control realms may be strong because the "consumers" can see, evaluate, and appreciate the "product" that they are buying, no such transparency exists with regard to environmental regulation. Tangible, demonstrable, and plainly apparent economic benefits of reduced environmental regulation overwhelm the uncertain, intangible, future costs associated with environmental degradation. The assumption of perfect information that undergirds perfect

223. For a discussion of basic Marshallian welfare theory, see RICHARD A. BILAS, MiCROECONOMIC THEORY: A GRAPHICAL ANALYSIS 67-80 (1967); Gerald D. Jaynes, Economic Theory and Land Tenure, in CONTRACTUAL ARRANGEMENTS, EMPLOYMENT, AND WAgeS IN RURAL LABOR MARKETS IN ASIA 43 (Hans P. Binswanger \& Mark R. Rosenzweig eds., 1984); Jerry A. Hausman, Exact Consumer's Surplus and Deadweight Loss, 71 AM. ECON. ReV. 662 (1981).

224. However, a beneficial regulatory competition process is likely to occur only under a narrow set of circumstances. See Truman F. Bewley, A Critique of Tiebout's Theory of Local Public Expenditures, 49 ECONOMETRICA 713, 714 (1981); Brian R. Copeland \& M. Scott Taylor, Trade and Transboundary Pollution, 85 AM. EcoN. REv. 716 (1995); James R. Markusen et al., Competition in Regional Environmental Policies When Plant Locations are Endogenous, 56 J. OF PUB. ECON. 55 (1995) (finding suboptimal "Nash" equilibriums under many circumstances when the assumption of perfect competition is put aside); Martin C. McGuire, Regulation, Factor Rewards, and International Trade, 17 J. PUB. ECON. 335, 354 (1982). But see FISCHEL, supra note 19 (spirited defense of the realism of the Tiebout model); William A. Fischel, Property Taxation and the Tiebout Model: Evidence for the Benefit View from Zoning and Voting, 30 ECON. LIT. 171 (1992).

225. See Ian Ayres, Supply-Side Inefficiencies in Corporate Charter Competition: Lessons from Patents, Yachting, and Bluebooks, 43 KANS. L. REv. 541, 543 (1995); Klevorick, supra note 213 , at 460 (stating that race to the bottom is "highly contextual"); James R. Markusen et al., Environmental Policy When Market Structure and Plant Locations are Endogenous, 24 J. ENVTL. ECON. \& MGMT. 69, 84 (1993); Stewart, supra note 210 , at 2059 (concluding that races to suboptimal outcomes will sometimes occur). 
competition theories cannot be squared with the reality of environmental policymaking: the invisibility and lag times of many environmental harms; threshold effects that produce unpredictable discontinuities in dose-response functions; and the natural political tendency to discount unknown and uncertain future harms. ${ }^{226}$ Revesz's theory can bear more weight if one assumes away technical transaction costs, but to do so is to distance oneself from environmental reality and to diminish the policy relevance of the work.

Second, politicians do not make environmental policy choices by equating the marginal costs and marginal benefits of lowering standards to gain a factory or to avoid losing one. Instead, industrial investments are "lumpy." Thus, the image generated by regulatory competition theory of governments carefully calibrating the price of their location rights (that is, the stringency of their environmental controls) to get the optimal level and kind of industry seems farfetched. ${ }^{227}$ In addition, in the bidding for capital investments, there may well be a "winner's curse" that results in a systematic overvaluation of the benefits of a new factory and a simultaneous undervaluation of its environmental costs. ${ }^{228}$ This tendency to overbid arises because in the competition for a new facility, the winner will be the jurisdiction most optimistic about the net value of the project and thus willing to bid the highest (by lowering its environmental standards the most). ${ }^{229}$ Finally, governments may lower environmental standards ${ }^{230}$ generally to signal their interest in attracting business and jobs. ${ }^{231}$ In such circumstances, when policy is set in the abstract and without any direct connection to the cost of acquiring the marginal firm, there may well be a tendency to overdo the signal and loosen standards too much. ${ }^{232}$

226. Revesz dismisses such results as "errors" in the policy process and argues that any race to the bottom that ensues is a function of the "state's failure to act in an economically rational manner." Revesz, supra note 1 at 1243. But this is an example of where theory and policy intersect. It is not clear that politicians are making an "error." Perhaps they are acting economically irrationally, but they certainly are not acting politically irrationally. If one's theory depends on assuming away noneconomic elements of political reality, the policy relevance of the analysis becomes quite limited.

227. See Markusen et al., supra note 224, at 69.

228. See Peter B. Swire, The Race to Laxity and the Race to Undesirability: Explaining Failures in Competition Among Jurisdictions in Environmental Law, Symposium, Constructing a New Federalism, Yale J. ON Reg. \& Yale. L. \& Poly. Rev. 68, 98 (1996).

229. See id.

230. "Lowering" environmental standards may not entail voting in lax rules but may simply involve less strict enforcement of existing rules.

231. There are many examples of such signals in states' or countries' advertisements about their business climates. See supra note 221 .

232. See Swire, supra note 228. 
Third, governmental bodies are relatively weak instruments of market discipline. ${ }^{233}$ Compare a hypothesized corporate charter race to the bottom with environmental regulatory competition. The original theory in this regard, advanced by Cary, is that company executives will seek to incorporate in Delaware because of the advantages that that state's laws provide in protecting managers' positions at the expense of shareholder welfare. ${ }^{234}$ Winter disputes this theory and argues that market forces constrain managers. ${ }^{235}$ Specifically, he observes that managers who routinely seek to protect themselves at the expense of the shareholders will become targets for takeovers or will drive their firms into bankruptcy.

In the environmental field, the "electoral market" constraining government "managers" works less directly. Political decisionmakers often are free to accept money and other benefits from polluters in return for advantageous regulatory decisions. Unifying the mass of voters who are negatively, but indirectly, affected as a result is extremely difficult. ${ }^{236}$ Thus, there is no comparable control on suboptimal political decisions about environmental regulation of the sort that exists in the market for corporate control. 237

The study of races to the bottom in the bank charter context supports a similar conclusion. ${ }^{238}$ Bank regulation, like environmental rules,

233. Although Revesz acknowledges this weakness in his analogy to perfect competition, he dismisses the concern as simply one arising from governmental undervaluation of environmental benefits and "not a consequence of the competition among states." Revesz, supra note 1, at 1235. But this cursory treatment of the public choice problem is insufficient. It is the very prospect of systematic undervaluation of environmental benefits by politicians that renders the analogy to a perfectly competitive market inapt.

234. See William L. Cary, Federalism and Corporate Law: Reflections Upon Delaware, 83 YALE L.J. 663, 663-84 (1974).

235. See Ralph K. Winter, Jr., Shareholder Protection and the Theory of the Corporation, 6 J. LEGAL STUD. 251, 262-73 (1977); see also Lucian A. Bebchuk, Federalism and the Corporation: The Desirable Limits on State Competition in Corporate Law, 105 HARV. L. Rev. 1435 (1992); Roberta Romano, The State Competition Debate in Corporate Law, 8 CARDOzo L. REv. 709 (1987).

236. See supra notes 51-52. Even Winter acknowledges that states should not be allowed to set their own rules regarding takeovers because the managers will not be good agents for the shareholders. See Winter, supra note 235, at 251-92; see also Mashaw \& Rose-Ackerman, supra note 111, at 118-21.

237. Again, Revesz could argue that the inefficiency arises here not because of regulatory competition but rather because of public choice failures. As a matter of pure theory, this might be correct, but to ignore the realities of the political marketplace reduces the strength of any policy conclusions that might be drawn from such theorizing.

238. See Henry N. Butler \& Jonathan R. Macey, The Myth of Competition in the Dual Banking System, 73 CORNELl L. Rev. 677, 713 (1988). 
represents a public good that is not purely local. The bank charter race arises because bankers protected by FDIC insurance can obtain above average returns through risky lending, confident that success will yield handsome rewards and that a significant portion of the costs of failure will be borne by others. As one state relaxes its regulatory control to enable its bankers to take advantage of this risk-spreading opportunity, other welfare-maximizing states will be tempted to follow suit to avail their own bankers and depositors of the opportunity for high rates of return. 239

This race might be triggered, even in the absence of the FDIC riskspreading scheme, by pressure on politicians to avoid disadvantaging local bankers. Even if all of the downside risk is borne locally, the structure of the bank charter problem, like pollution harms, entails uncertain future risks that might lead a welfare-maximizing politician toward lax regulation given that the benefits of high returns will accrue immediately while the costs will arise in the future (perhaps even on someone else's watch) if at all. When some of the costs clearly will be spread to others (through FDIC insurance or pollution spillovers), the calculus favoring lax regulation and tending to create a race to the bottom becomes overwhelming. ${ }^{240}$

Finally, even if one assumes that the technical analysis of one's own jurisdiction is perfect and that no physical pollution spillovers or public choice distortions exist, one cannot be assured of a welfaremaximizing process of regulatory competition if any other jurisdiction suffers from either technical inadequacies or public choice flaws. Once any party moves off its "true" optimal level of environmental regulation - to a standard that is either too high or too low - others cannot be assured, under the Theory of Second Best, that staying with their own "island jurisdiction" optimization strategy will continue to maximize welfare. ${ }^{241}$ The conclusion I draw is a modest one: the scope for failure in the market for environmental-policy-determined location rights is significant enough to make untenable a presumption that regulatory competition in this domain will be welfare enhancing.

239. This analysis relaxes the assumption that there are no interjurisdictional spillovers, reflecting the reality of both national insurance schemes and many pollution problems.

240. Revesz again could argue that the bank-charter-policy failure arises because of either externalities or public choice problems - not the dynamics of competition. Once again, this rests the theory on very narrow and counterfactual assumptions. Note, furthermore, that Butler and Macey's solution to the bank charter race - risk-adjusted FDIC rates - relies on more refined central regulation, not state-based control.

241. See Anderson, supra note 210, at 12 (arguing that when there is more than one distortion, optimizing any particular policy dimension may not increase welfare). 
b. Economic Models. A second strand of regulatory competition theory consists of extensions of the Tiebout hypothesis. ${ }^{242}$ Early models, Tiebout's included, are based on problematic assumptions. ${ }^{243}$ But Revesz and other regulatory competition theorists rely on the latest refinement of the hypothesis by Oates and Schwab, which aims to overcome these shortcomings. ${ }^{244}$ Ironically, Oates and Schwab can be read to corroborate race-to-the-bottom fears, as they find interjurisdictional competition efficiency enhancing only under tightly defined circumstances. ${ }^{245}$ If governments rely - as they all do - on "inefficient tax instruments," including nonzero taxes on capital, welfare-diminishing levels of pollution result. Oates and Schwab further note that other "distortions," such as policy decisions that deviate from the will of the electorate or the existence of "conflicts of interest within a heterogeneous community," also lead to suboptimal results. ${ }^{246}$

Recognizing the pervasiveness of positive tax rates on capital, Revesz strains to rescue his argument by claiming that these suboptimal results are "due to an 'error' on the part of state regulators rather than to a structural failure of state autonomy in a federal system." ${ }^{247}$ In the end, Revesz's theoretical dismissal of the race to the bottom depends on heroic assumptions, including perfect governmental rationality, a point of departure not unlike the Tiebout and Fischel models with which he himself finds fault.

242. See supra text accompanying notes 136-37.

243. Tiebout's model assumes that: (1) individuals are entirely mobile and choose to live where the taxes imposed and the services provided best match their own "preference patterns"; and (2) everyone lives on dividend income and therefore is immune to job loss concerns. As the North American Free Trade Agreement (NAFTA) debate made clear, in the real world jobs are an issue. In addition to their restrictive assumptions, the work of Tiebout and Fischel can be criticized on a number of other grounds. In particular, their models fail to address the problems of shifting majorities, agenda manipulation, and strategic behavior. See Susan Rose-Ackerman, Tiebout Models and the Competitive Ideal: An Essay on the Political Economy of Local Government, in Perspectives on local Public Finance and Public Policy 23, 36-41 (John M. Quigley ed., 1983).

244. See Revesz, supra note 1, at 1242.

245. See Oates \& Schwab, supra note 4, at 350.

246. See id. at 351; see also Susan Rose-Ackerman, Beyond Tiebout: Modeling the Political Economy of Local Government, in LOCAL PROVISION OF PUBLIC SERVICES: The Tiebout Model After Twenty-Five Years 55, 59-65 (George R. Zodrow ed., 1983) (demonstrating that if the assumption of homogeneity within each community is dropped so that majority positions outvote minority ones, new voting instabilities emerge).

247. Revesz, supra note 1, at 1243. As Richard Stewart notes, one does not even have to assume extreme myopia on the part of governments, but simply standard setting under conditions of uncertainty. See Stewart, supra note 210, at 2045-56. 
More significantly, Revesz does not leave the argument at this point. Rather than offering the conclusion that under some circumstances interjurisdictional competition may not lead to a race to the bottom, ${ }^{248}$ he takes two further steps. From the shaky ground of his analysis of Tiebout and regulatory competition theory, and seemingly in contradiction of himself, ${ }^{249}$ Revesz dismisses the theoretical possibility of races to the bottom and makes the additional leap to a policy prescription presumptively favoring decentralized regulation. ${ }^{250}$ It is here that his logic most seriously falters.

First, the suggestion that there is no theoretical foundation for the race-to-the-bottom dynamic either rests on too narrow a set of assumptions to be of much interest, or overstates the conclusions that can be drawn from Oates and Schwab and their progeny. Models demonstrating the logic of a race to the bottom under certain circumstances abound. ${ }^{251}$ That other models premised on other assumptions show that competitiveness-driven suboptimal environmental policies need not ensue does not support the claim that there is no theoretical basis for the

248. Revesz tries to bolster his dismissal of race-to-the-bottom concerns with the observation that states sometimes exceed federal standards. See Revesz, supra note 1, at 1228. But his anecdotal examples only further prove the difficulty of making sweeping conclusions, since for every example of states exceeding federal standards that Revesz cites, a recent example of states reducing their environmental controls to reestablish their competitiveness can be identified. See, e.g., Joel Stashenko, NY Eases off Lake Pollution Agreements, Rutland HeRALD, July 28, 1995, at 1 (explaining New York's decision to back away from phosphorus emissions controls in Lake Champlain); James P. Sweeney, Environmental Bloc Holds Its Own, But Wait till Next Year, SAN DIEGO UNION-TriB., Sept. 22, 1995, at A6 (reporting on the scaling back of environmental regulation in California); James Rusk, Ontario Proposes Environmental Law Overhaul, TORONTO GlOBE \& MAIl, Aug. 1, 1996, at B13 (reporting on Ontario's "sweeping overhaul" of its provincial environmental regulations that would relieve pulp mills from eliminating chlorine, reduce testing for toxics, and other pollution reducing "burdens"). Whether a particular environmental issue will engender a competitiveness-inspired raceto-the-bottom or a NIMBY-induced race to the top depends on the structure of the particular problem. See John Douglas Wilson, Capital Mobility and Environmental Standards: Is There a Theoretical Basis for a Race to the Bottom?, in FAIR TRADE AND HARMONIZATION, supra note 132, at 393.

249. Revesz's own analysis reveals a race if the structure of the relevant game is a prisoners' dilemma. See Revesz, supra note 1, at 1230-33.

250. See id. at 1253.

251. See Eric W. Bond \& Larry Samuelson, Bargaining With Commitment, Choice of Techniques and Direct Foreign Investment, 26 J. INTL. ECON. 77 (1989) (finding a race to the bottom under a pure property tax scenario); Sam Bucovetsky \& John Douglas Wilson, Tax Competition with Two Tax Instruments, 1991 REGIONAL SCIENCE AND URBAN ECONOMICS 333, 349 (showing that public goods are underprovided when wages are taxed, even capital is not); Markusen et al., supra note 224, at 82-84 (showing "lumpy" investments result in a race to the bottom); Oates \& Schwab, supra note 4, at 342-45 (illustrating a race in which capital is taxed); Wilson, supra note 248 (discussing a race to the bottom under varying conditions). 
race to the bottom unless Revesz can demonstrate that his picture of the environmental policy process more closely resembles reality than do competing views. This he cannot do.

Second, just because a race to the bottom need not occur does not mean that it will not occur. In fact, to the extent that the no-need-toworry viewpoint depends on numerous, and often counterfactual, assumptions, the theoretical existence of a world where races to the bottom do not arise provides little basis for optimism that welfareenhancing regulatory competition will emerge broadly in the real world. Indeed, Revesz's greatest misstep derives from his attempt to draw policy conclusions. He lays down the gauntlet early by challenging environmental federal regulation as "likely to produce results that are undesirable." 252 While we might all agree that the current structure of regulation produces undesirable results, Revesz does next to nothing to show that the source of the problem is the federalness of the regulations.

Ultimately, Revesz's argument that a race to the bottom is not inevitable cannot support the weight he puts on it. Having knocked a brick out of the foundation of federal environmental regulation, Revesz could have asserted that centralized regulation is not justified in all circumstances. He could have then provided examples of cases in which regulatory competition might be preferable. But this is not his claim, as he makes no attempt to delimit the sphere in which his argument holds.

From a policy perspective, the key question is not whether, theoretically, we could design a world without races to the bottom, but whether we now live in one. Interstate pollution spillovers are pervasive, as are public choice distortions of the political process. The fact that politicians set environmental standards strategically with an eye on potential job losses and the investment effects of their policies should not be surprising. ${ }^{253}$ The view that we can avoid races to the bottom by getting governments to adopt more sophisticated taxation schemes and otherwise acting in a manner that represents perfect economic rational-

252. Revesz, supra note 1 , at 1212.

253. See, for example, reports on the 1990 Clean Air Act debate, such as: Margaret E. Kriz, Politics in the Air, 21 NATL. J. 1098 (1989); Robert Kasten, Jr., Why Reich is Wrong on Jobs, WASH. TIMES, June 8, 1993, at F1 (discussing Clean Air Act job effects). See also ESTY, supra note 52, at 21-23. The European Union's inability to implement a proposed carbon-BTU tax offers further evidence of the salience of competitiveness concerns in environmental policymaking. See Electricity Companies Confirm Opposition to EC Carbon Tax Proposals, Press Assn. Newsfile, July 2, 1993, available in LEXIS, News Library, Panews File; Colin Moynihan, Changing Stars For Energy's Direction, DaILy TelegRAPH (London), Feb. 21, 1993, at 39. 
ity and public representativeness may be correct. ${ }^{254}$ Yet in the realm of practice rather than theory, environmental policymakers remain justified in fearing the dynamic of a regulatory race to the bottom. ${ }^{255}$

\section{Psychological Externalities, Internalities, and the "Choice of Public"}

From a pure welfare maximization perspective, nonuse or existence values of environmental resources should be taken into account in setting environmental policy. For example, the value Americans place on African elephants should be reflected in African elephant conservation policy decisions. The ethereal nature of psychological spillovers casts doubt, however, on the substantiality of these welfare claims. Even if the utility gains or losses from such spillovers can be documented, another question must be asked: Do the claims rise to the level of a property right? If not, they may not need to be factored into the regulatory cost-benefit analysis. ${ }^{256}$

a. Choice-of-Public Issues. In important respects, nature and geography define the optimal scope of governmental intervention in the environmental realm. While regulatory strategies generally are established along political boundaries such as cities, states, and countries, ecological problems almost never conform to these often artificial borders. ${ }^{257}$ Thus a regulatory response conforming to political boundaries will often be suboptimal. Moreover, a second dimension to the optimal regu-

254. See Revesz, supra note 1 , at 1243 ; Wilson, supra note 248 , at 36 .

255. Revesz suggests that even if there exists a race in the environmental domain, federal regulation may still not be called for because halting the environmental policy race will simply drive state-versus-state competition into other arenas, such as worker safety or minimum wages. See Revesz, supra note 1, at 1244-45. This suggestion makes little sense. Fundamentally, this line of analysis fails to recognize the technical complexity of environmental policymaking as well as the irreversible nature of some environmental harms. Thus, driving interstate competition out of the inherently obscure realm of environmental policy and into that of other governmental activities, where the costs and benefits of various policies are more easily compared, will be beneficial.

256. One might argue that such interests represent only a conditional right, that is, one that can be enforced only if it is paid for. Thus, Americans with an interest in African elephants or the Amazonian rain forest might be entitled to have their desires factored into the Kenyan or Brazilian policy process only to the extent they were willing to pay. But some commentators argue that certain resources (forests supporting biodiversity, for example) are global public goods creating property rights and not merely conditional interests for which payment must be made. See Christopher D. Stone, What to do About Biodiversity: Property Rights, Public Goods, and the Earth's Biological Riches, 68 S. CAL. L. REv. 577, 583, 619 (1995). But see EsTY, supra note 52, 125-26 (arguing that extrajurisdictional beneficiaries should pay).

257. Ironically, political boundaries defined by nature, such as a river establishing a state border, tend to divide ecosystems in ways that are unhelpful from an environmental policy point of view. 
latory jurisdiction is defined by the concept of citizenship, and therefore bounded by the reach of the "community." Because citizenship implies duties to fellow citizens, those within the community are entitled to have their views factored into the policy process; those outside are not. Decisions about the management of the Grand Canyon, for example, properly include the value placed on this resource by all Americans. ${ }^{258}$ The physical bounds of an environmental resource or pollution harm should determine the choice of public question and the optimal jurisdiction for environmental regulation unless the relevant community is bigger, in which case the community defines the proper scope of governmental activity.

Identifying the community vis-à-vis environmental issues can present a serious challenge. In some circumstances, political boundaries delimit communities of shared values and thus prove useful in defining the optimal regulatory unit. In many cases, however, environmental interests and values are not coterminous with existing jurisdictional lines. What happens, for instance, when "others" mismanage environmental resources from which "we" derive some benefit? Some legal scholars intimate that this question is trivial and that "we" can only legitimately be concerned about our own political jurisdiction's policies and have no business worrying about the "mistakes" that others make. 259 Many economists also implicitly accept the division of the world into a "we" about whose utility we care and a "they" about whom we do not care. Nordhaus, for example, argues that if other jurisdictions set suboptimal environmental policies, we should not worry and might even have cause for celebration. ${ }^{260}$ Low standards in other jurisdictions will shift "dirty" industries to their territory, sparing us from pollution and providing us with goods at lower prices. In effect, such jurisdictions subsidize our consumption of certain goods that otherwise would be more expensive because of our pollution control costs.

But "we" may not be better off when a neighboring jurisdiction makes an environmental regulatory mistake, even one in which the physical harm is confined to that jurisdiction. Nordhaus is right to be concerned with the utility of a defined "us," but the meaning of that term now has broadened for many environmental issues such that a dis-

258. The community is defined here by the fact that the resource is a national park, acquired in the name of all Americans. Communities also may be defined by a sense of shared values, common traditions, or other linkages.

259. See Richard Posner, Utilitarianism, Economics, and Legal Theory, 8 J. LEGAL STUD. 103 (1979). This line of thinking does not help us answer the question of to what jurisdiction - town, county, state, nation, or world - we are to look for answers.

260. See Nordhaus, supra note 28. 
tinct "they" is no longer identifiable. Interest in distant environmental harms may derive from a sense of community identity that exceeds narrow jurisdictional bounds. Simultaneously, our sense of community may be broadened by an expanded interest in environmental issues. In some cases, the utility of people in other places, even other countries, may become subsumed within our own utility calculus, and to that extent "they" become a part of "us." 261

It seems doubtful, for example, that many Americans exposed to stories about horrendous environmental conditions in China would, as economists might forecast, react with glee at the prospect of obtaining products subsidized by a Chinese willingness to absorb environmental insults considered unconscionable here. Instead, the informed public reacts with revulsion, even outrage. ${ }^{262}$ Beyond the threat of physical spillovers that might harm America, ${ }^{263}$ I suspect that Americans feel some identity, despite all their political differences, with the Chinese people who must breathe acrid air. ${ }^{264}$

In other cases, the health of ecosystems to which we have no physical connection may enter directly into our utility calculus. Americans who will never visit Yellowstone National Park value its preservation. ${ }^{265}$ After the Exxon Valdez oil spill, tens of thousands of school children

261. In such circumstances, "our" welfare is linked to "their" welfare, or, in other words, our utility functions are interdependent.

262. Consider the recent high degree of outrage over the importation into the United States of products made in sweatshops. See, e.g., Steven Greenhouse, A Crusader Makes Celebrities Tremble, N.Y. TIMES, June 18, 1996, at B4; Steven Greenhouse, Labor and Clergy are Reuniting to Help the Underdogs of Society, N.Y. TIMES, Aug. 18, 1996, at A1; Harry F. Rosenthal, Manufacturers Agree on No-Sweatshop Guarantees for Shoes, Clothes, AP. Aug. 2, 1996, available in 1996 WL 4434191.

263. China is the world's second largest emitter of greenhouse gases, and it is forecast to be the world's largest emitter by early in the next century.

264. Part of this connection may derive from a sense that the Chinese authorities' indifference to the suffering caused by environmental damage borders on a violation of human rights. In the realm of natural rights, "we-they" distinctions do not exist. See, e.g., I U.N. WORLD CONFERENCE ON HUMAN RIGHTS: VIENNA. DECLARATION AND Programme of ACTION, U.N. Doc. A/Conf.157/24 (1993), reprinted in 32 INTL. LeGAL MATERIALS 1661, 1665 (1993) ("All human rights are universal, indivisible, interdependent and interrelated."). Interestingly, Adam Smith argued that the destruction of all of China would not cause a man of humanity in Europe to lose a moment's sleep, whereas the loss of his own finger would cause him to sleep not a wink. See ADAM SMITH, The TheORY OF Moral Sentiments 136-37 (D.D. Raphael \& A.L. Macfie eds., Clarendon Press 1976).

265. There is a growing literature on "existence values" and "contingent valuation" that tries to measure these welfare gains and losses. See, e.g., ROBERT CAMERON Mitchell \& Richard T. Carson, Using Surveys to Value Public Goods: The Contingent Valuation Method 6467 (1989); Frederick R. Anderson, Natural Resource Damages, Superfund, and the Courts, 16 B.C. ENVTL. AFF. L. REv. 405, 407-08, 408 n.5 (1989); Jeffrey C. Dobbins, The Pain and Suffering of Environmental 
sent the EPA letters and pictures expressing distress over the fate of sea lions, birds, and other wildlife. Although only a tiny fraction of those students ever will visit Prince William Sound, one cannot doubt the sincerity of their identification with the environmental injury that occurred there.

The extent of our interest in a distant environmental harm is also likely to be determined by the scope and severity of the harm itself and by our confidence, or lack thereof, that those on the scene are handling the problem appropriately. When other jurisdictions reveal themselves to have no effective means for addressing environmental harms, our political identity may expand to encompass even very remote injuries. ${ }^{266}$ Just as human rights violations matter to those whose rights are not violated, so too a total disregard for the impact of pollution on human health or ecosystems may lead others to conclude that the failing state has forfeited its claim to sovereign environmental policy judgments. In the context of our current national debate over environmental federalism, this "state failure" argument is hardly an academic concern because some U.S. states simply lack the regulatory capacity to respond adequately to all environmental problems. ${ }^{267}$

For present purposes, I make this political identity argument solely as a matter of fact. I do not advocate greater popular sensitivity to physically distant environmental harms, but merely observe that such harms increasingly figure into our utility and disutility assessments. The interconnectedness of modern life is much more extensive and complex than is suggested by a simplistic focus on pollution impacts within immediately shared physical space or narrowly defined political borders. As people regard themselves as part of an ecologically defined community, they come to define themselves as a political community as well, often to a greater extent than mere physical interdependence would demand. I grew up, for instance, in Western Connecticut alongside the Naugatuck

Loss: Using Contingent Valuation to Estimate Nonuse Damages, 43 DuKE L.J. 879, 880-81 (1994).

266. China's runaway pollution may evolve in this direction. Concern about mismanagement of the rainforests of the developing world may also reflect such sensibilities.

267. See Sam Schuchat, Unfit Stewards, N.Y. Times, Sept. 20, 1995, at A21 (identifying examples of weak state environmental protection efforts); see also supra note 165 (discussing weaknesses in state "capacity"). A number of existing federal environmental programs seem to reflect, moreover, a national ecological and political identity that spans the fifty states. One could argue, for example, that the Clean Water Act's construction grants program, providing federal funds to build wastewater treatment facilities, represents a commitment that no American should live in a community where untreated sewage flows into nearby rivers. See Clean Water Act $\S \S 201-219,33$ U.S.C. $\S \S 1281-1299$ (1994). 
River, which flows from Massachusetts to Long Island Sound. Those living in the area of the river often describe themselves as being from the Naugatuck Valley. This is not simply because downstream residents may be polluted by upstream users of the river, but because the presence of a shared resource creates a political community. ${ }^{268}$ Why else would upstream users identify with downstream users, from whom they do not anticipate direct physical spillovers? Similarly, many people have important aspects of their political identity established by their proximity to the Chesapeake Bay, the Gulf of Mexico, the Mississippi River, the Great Plains, the Rocky Mountains, Puget Sound, or the Central Valley. ${ }^{269}$ Nature defines our sense of community and makes us more cosmopolitan. More fundamentally, we live in an era in which political boundaries matter but do not uniquely describe community identity. ${ }^{270}$ Our analysis of the optimal scale of environmental regulation should reflect this fact.

This choice of public analysis also should be seen as an extension of the learning of international law over the past fifty years. Specifi-

268. From the transcendentalism of Thoreau to Aldo Leopold's admonition to "think like a mountain," Americans have long recognized the role nature plays in transforming man's understanding of himself. But my argument here is a little different. I see man's relationship to man as defined by nature. Geography - the fault lines of natural resources and ecosystems - shapes people's sense of identity in important ways and thus establishes the relevant community for governmental activity in the environmental realm. Those who see themselves as residents of the Gulf Coast, for instance, care not only about how their own community and state affect the quality of life on the Gulf; they also care about how neighboring cities and states respond to the environmental challenges that the Gulf presents - and even how neighboring countries such as Mexico and those of the Caribbean Islands manage their portions of this shared space. Obviously, environmental policy errors in the next town over matter much more than ones thousands of miles away. Nevertheless, people have a nontrivial interest in environmental policies being made much farther afield. Echoes of this geography-and-naturedefines-the-community theory actually run deep in American history. For example, Thomas Paine argued that the physical distance from Great Britain made rule of the colonies inappropriate. See Thomas PAINe, Common Sense 90 (Isaac Kramnick ed., Penguin Books 1982) (1776); see also Akhil Reed Amar, Some New World Lessons for the Old World, 58 U. CHI. L. REV. 483, $485-97$ (1991) (stressing the importance of geography in defining the optimal physical scale of a political jurisdiction).

269. Interestingly, some of the EPA's most successful recent initiatives have been "geographically defined" - focused on the Chesapeake Bay, the Great Lakes, etc. and have tapped into this nature-determined sense of political identity.

270. Most people see themselves as part of a variety of communities, with geographically defined political identities being only one - and perhaps not even the most important - of the units around which their lives are organized. When it comes to environmental problems, people are particularly unlikely to define themselves merely on political-jurisdictional lines, especially if these are narrowly local or state-based. See Jerry Frug, Decentering Decentralization, 60 U. CHI. L. REv. 253, 262-63 (1993) (observing that few people have a sense of community defined by local political jurisdictions). 
cally, interdependence in many forms mutes territorial sovereignty. ${ }^{271}$ Cuius regio, eius religio, the 350-year-old axiom of the Peace of Westphalia establishing a strict principle of national territorial domain as the foundation for relations among states, cannot be counted upon to maximize social welfare in a world of pervasive economic and ecological linkages. ${ }^{272}$ The current devolutionary mood ignores this complex interdependence. ${ }^{273}$ In doing so, it puts at risk some of the important benefits that accrue from having a broader political identity.

Broad-scale regulatory decentralization, for instance, threatens to disrupt the free movement of goods and services across the fifty states. Suppose, for example, that labor standards were deregulated entirely, and Idaho chose to abandon all limitations on child labor. California then might seek to block goods from Idaho as morally subpar, just as today Americans object to the importation of goods produced by Bangladeshi child laborers or Chinese prison workers. In the U.S. context, such threats would be constrained by the constitutionally mandated interstate customs union, but the level of political outrage might be considerable. In fact, in an earlier era, President Franklin Roosevelt argued that federal labor standards were needed for just this reason. In striving to protect the national free trade regime, he declared that "[g]oods pro-

271. See generally Abram Chayes \& Antonia Handler Chayes, THE New SOVEREIGNTY: COMPLIANCE WITH INTERNATIONAL REgULATORY AgREEMENTS (1995); Myres S. McDougal et Al., Human Rights and World Public ORDER 367-449 (1980); Emest S. Easterly III, The Rule of Law and the New World Order, 22 S.U. L. REv. 161 (1995); Harold Hongju Koh, Transnational Public Law Litigation, 100 YALE L.J. 2347 (1991).

272. The concept of territorial sovereignty emerged, moreover, in response to the very specific problem of Europe's seventeenth-century religious wars and worked to control intolerance in a world of religious diversity. Today's environmental situation is not parallel. In an ecologically interdependent world, what others do within their sovereign borders cannot be ignored. Tolerance is not necessarily a virtue in the environmental domain. If Pennsylvania and New Jersey foul the Delaware River, the downriver citizens of Maryland pay the price. If China releases CFCs, the whole world's ozone layer deteriorates, not just the part over China. In the environmental domain, a principle of "you do what you want in your territory and I will do what I want in mine" does not work.

273. Recognition of the economic interdependence and other interconnections of modern American society served to underpin the centralization of government advanced during the New Deal. See, e.g., Natural Resources Committee, The STrucTURE OF THE AMERICAN ECONOMY (1939), cited in HENRY M. HART, JR. \& ALbert M. Sacks, The Legal Process: Basic Problems in the Making and APPLICATION OF LAW, at lxii (rev. ed. 1994). The understanding that law provided the "conditions of continuity" needed to facilitate complex human interactions of the sort that are commonplace in a national economy emerged at this time and provided the foundation for the prosperity the United States has achieved as the world's largest unified market. See id.; see also THE RELEVANCE OF INTERNATIONAL LAw (Karl W. Deutsch \& Stanley Hoffman eds., 1968). 
duced under conditions which do not meet rudimentary standards of decency should be regarded as contraband and ought not to be allowed to pollute the channels of interstate trade." ${ }^{274}$ In effect, Roosevelt recognized the need to respond to the regulatory demands of the political community created as a result of the free trade regime itself. The same logic applies to baseline environmental standards.

Maintaining a free trade area requires a core set of accepted common norms to guide behavior within the community. ${ }^{275}$ Indeed, many would argue that the existence of shared values is what defines a community. Because those in the community have a legitimate interest in the terms on which commerce is conducted by others in the community, they must be able to establish guidelines for behavior that all will follow. ${ }^{276}$ Centralized ground rules for commerce, including environmental conditions, are part of the bargain that makes liberalized trade possible. ${ }^{277}$ Without centrally determined moral baselines for economic interactions, parties to free trade agreements face constant temptations to disregard the principle of nondiscrimination ${ }^{278}$ and to breach their obligations to keep their markets open to others whenever another party conducts its affairs in a manner that could be deemed unacceptable. ${ }^{279}$

274. President's Message to Congress on The Fair Labor Standards Act (May 24, 1934), reprinted in S. REP. No. 75-884, at 2 (1937); see also id., quoted in Powell v. United States Cartridge Co., 339 U.S. 497, 516 (1950).

275. In addition, "shallow" integration (lowering of tariff barriers) often leads to "deeper" integration (across regulatory policies, etc.). See ROBERT Z. LAWRENCE ET AL., A VISION FOR THE WORLD ECONOMY 5 (1996).

276. Of course, there always exists a risk that the baseline rules will be manipulated by rent-seeking interests whose goal is not "fair" trade but protectionism. See ESTY, supra note 52, at 45-46.

277. The threat of trade disruptions from differences over environmental policy are very real, as can be seen from the steady stream of "trade and environment" disputes that have recently faced the international trading regime. See ESTY, supra note 52, Appendix $\mathrm{C}$ (listing recent disputes). The prospect of California imposing trade penalties on Idaho in the same way that the United States has imposed them on Mexico and other countries seems remote given the protection afforded by the Constitution's Commerce Clause. But the lack of past state-versus-state efforts to impose trade penalties over perceived moral failings provides no guarantees against future tensions, especially if a radically decentralized regulatory structure were to emerge.

278. The "nondiscrimination principle" that compels the parties to treat foreign goods and producers as they treat their own goods and producers is the heart of any free trade agreement. See U.S. CoNST. art. $1, \S 8$, cl. 3 (Commerce Clause); General Agreement on Tariffs and Trade, opened for signature Oct. 30, 1947, arts. I, III, 61 Stat. A3, A12-A13, A18-A19, 55 U.N.T.S. 187, 196-200, 204-08 [hereinafter GATT].

279. One of the core problems with Revesz's regulatory competition analysis and the arguments of others seeking to decentralize all regulation is that they implicitly assume that trade policy will not be decentralized and that the considerable benefits of liberalized trade will be preserved despite environmental policy devolution. If, however, decentralization is preferable in the environmental realm, why not in trade? The answer 
At the very least, total regulatory decentralization puts stress on the free trade regime as states express revulsion at the prospect of keeping their markets open to ethically suspect imports and of losing jobs and investment to other states whose standards seem to dip below a moral minimum. ${ }^{280}$ In fact, decentralization may expose the parties to a free trade agreement to the potentially high costs of adjudicating moral claims on a case-by-case basis, and to the regular disruptions of trade that unilateral moral judgments inflict. The alternative is to recognize that in return for the welfare gains of being part of a free trade community, one must surrender a measure of sovereignty and accept at least a core set of centrally determined baseline behavioral rules, including environmental standards. ${ }^{281}$

Interdependence, moreover, may be self-reinforcing. As interdependence in one dimension becomes recognized and the political community is redefined accordingly, that same redefinition will create additional dimensions of interdependence. For example, "shallow" economic integration such as agreement on a free trade zone creates a "thin" community that may thicken over time as people recognize other aspects of their common enterprise. The strengthening of the political community leads to common noneconomic projects like environmental protection that make possible "deeper" economic integration. ${ }^{282}$ The progress of European unification demonstrates this phenomenon. Focused initially only on coal and steel, the European Union has grown to encompass a broad set of economic issues, and more recently environmental issues as well. ${ }^{283}$ The process of further integration now de-

is obvious: If decentralized jurisdictions are given sovereignty over their trade policies, there can be no guarantee that markets will be kept open. The world's experience with "beggar thy neighbor" behavior is long and sordid. See JOHN H. JACKSON, WORLD TRADE AND THE LAW OF GATT 9-10, 37-39 (1969).

280. Ironically, many of those who seek decentralization - which implies acceptance of the ethical standards others choose to set for themselves - are also sharp critics of moral relativism when it comes to international affairs.

281. The GATT also recognizes the need, in some areas, for minimum thresholds for behavior that establish the minimal sense of community required to support economic integration. Products of prison labor, for example, are not entitled to nondiscriminatory treatment. See GATT, supra note 278, art. XX.I(e), 61 Stat. at A61, 55 U.N.T.S. at 262. This moral and political dimension of the argument for some degree of centralized environmental regulation echoes the pyramids of sacrifice rationale for federal regulation articulated by Professor Stewart. See Stewart, Pyramids, supra note 7, at 121719.

282. The demand for labor and environmental side agreements to the NAFTA may reflect the same dynamic. See LAWRENCE ET AL., supra note 275.

283. See ANDré SAPIR, The HARMonization of Social Policies: Lessons FROM EUROPEAN INTEGRATION (1994). The limits of Europe's political redefinition, however, currently are being tested as certain members of the Union resist the efforts of 
pends on the development of a stronger European identity and sense of community, which will result in greater interdependence. ${ }^{284}$ As interdependence grows, so too does the need for new areas of cooperation to allow states more flexibility in making the policy trade-offs that collective action inevitably demands. ${ }^{285}$ Adding the environment to the list of community ventures serves this purpose. ${ }^{286}$ How far this process will continue is hard to predict. Indeed, there is no reason to suppose that community redefinition - both expansion and contraction - moves ineluctably toward any particular end.

In sum, there exists no clear line between "us" and "them" in the environmental realm. In certain important respects the biosphere cannot be subdivided. Despite the current devolutionary climate, ecological interdependence is a fact. ${ }^{287}$ A Kantian cosmopolitan perspective in which each person defines himself politically at least in part as a citizen of the world is an inescapable reality in the realm of environmental policy. ${ }^{288}$ This universality demands, at some level and to some degree, integrated environmental protection programs across state and even national boundaries.

To the extent that we have a worldwide political identity, we need a set of global environmental norms to guide our behavior as citizens on this scale. Similarly, to the extent that we have a national political identity as Americans, there will be another (probably more numerous and more specific) set of environmental rules that represents the moral

other members to broaden the European policy agenda to encompass an ever-growing number of issues. The extent to which environmental issues are within the ambit of this new European community remains to be seen.

284. This need for a European political community lies behind the current debate about the EU's "democratic deficit." See, e.g., J.H.H. Weiler, The Transformation of Europe, 100 YALE L.J. 2403, 2466-74 (1991).

285. See Ernst B. HaAs, The Uniting of Europe: Political, Social, and ECONOMIC FORCES 486-527 (1958).

286. See John G. Ruggie, The Future of International Organizations (1981); see also JOHN EASTBY, FUNCTIONALISM AND INTERDEPENDENCE (1985) (discussing and synthesizing the work of Ernest Haas).

287. In fact, the impetus behind devolution may well be an increasing awareness (and dislike) of interdependence. Devolution, in other words, may be an isolationist response to an integrating world.

288. This is true even if Kant's own policy prescription, a "Union of Nations," seems hopelessly idealistic. See IMMANUEL KANT, Idea for a Universal History with Cosmopolitan Intent, in THE PHILOSOPHY OF KANT 116 (Carl J. Friedrich ed., 1949); see also John Locke, Two Treatises on Government 397 (Peter Laslett ed., Cambridge Univ. Press 1960) (1698) (describing all mankind as part of "this great and natural Community"); John Dunn, The Nation State and Human Community: Life Chances, Obligation, and the Boundaries of Society 37 (1993) (unpublished manuscript, on file with author) (discussing "the collective ecological imperative to save a habitat for the human species as a whole"). 
behavioral minimum that each citizen owes to his fellow citizens. Given these elements of community identity, a presumption in favor of decentralized environmental regulation cannot be justified because it prejudges the critical question of the relevant political community vis-àvis the environmental problem at hand. The existence of resource management and environmental problems of different scales and of communities of interest of varying sizes makes manifest the case for a corresponding hierarchy of regulatory structures.

b. Internalities. Broader jurisdictions, of course, increase the risk of internalities. ${ }^{289}$ Sensitivity to this type of structural regulatory failure lies behind much of the recent political momentum for environmental devolution. ${ }^{290}$ Admittedly, the welfare losses from less accurate centralized representation can be serious. Yet internalities do not make the case for total decentralization, given the presence of technical scale economies or transjurisdictional externalities; selective or partial devolution makes more sense.

Federal law should facilitate such devolution. ${ }^{291}$ National standards, for example, should be either true baselines or tailored to varying local conditions. When communities want to exceed federal standards, they generally should be free to do so. ${ }^{292}$ Policymakers must recognize, furthermore, that there exists a trade-off between devolution designed to address internalities and centralization that minimizes the welfare loss from externalities. The jurisdiction that is of optimal size for one problem will not be right for another. Even within a single policy area, the physical externality argument may point to one scale for intervention, while the scope of the community might argue for another, and the risk of a race to the bottom yet a third. Hybrid regulatory systems capable

289. As the previous section indicates, some internality claims reflect a constricted sense of community and should not be accepted.

290. See, e.g., GINGRICH, supra note 1, at 9; see also Butler \& Macey, supra note 157 , at $31-33$.

291. In general, it will be easier to devolve appropriate degrees of authority from a central base than to coordinate among initially decentralized jurisdictions because internalities generally do not present a zero-sum game. Pure internalities can be fixed by letting a subjurisdiction go its own way at no cost to those in the broader jurisdiction. In the externality case, if the costs thrown onto "outsiders" are to be internalized, the "insiders" who have not been paying to address the harm must do so. To internalize positive externalities, the outsiders must be asked to pay for benefits that previously have accrued to them for free.

292. This freedom makes unequivocal sense in the case of production process standards. When product standards are at issue, the benefits of having a national market with economies of scale for producers must be weighed against the benefits of locally tailored product requirements. 
of addressing various problems and parts of problems at different levels of aggregation therefore make sense.

Minimizing structural welfare losses requires a case-by-case jurisdictional matching principle. Problems that are by-and-large local in scope (waste site cleanups, drinking water quality, and spending on playgrounds, for example) should be regulated at the local level. Problems that arise on a regional scale (controlling pollution in a river system or an airshed, for example) should be managed on an ecosystem basis across states or even countries when necessary. To the extent that an environmental problem, such as acid rain, spans a great number of states, a national regulatory structure may be required. When problems, such as depletion of the ozone layer by CFCs are worldwide in scope, regulation on a global scale will be optimal from an environmental perspective.

\section{Public Choice}

Ensuring that environmental regulation reflects local knowledge and local priorities makes sense. Bureaucrats in Washington (or even in regional offices of the federal EPA) cannot know the future land use of a contaminated waste site as well as those in the community where the site is located. In deciding "how clean is clean enough," local judgment is essential. Similarly, while the sandstone buttes of Utah may look remarkable to an Easterner (and thus worthy of national park status or similar protection), citizens of Utah will know that this geography is relatively commonplace in their area and thus that not every butte deserves federal protection. ${ }^{293}$ In such cases, decentralization improves the decisionmaking process. Broad-based participation in the policy process, moreover, serves an important educational function ${ }^{294}$ and may yield outcomes that are perceived as more fair. ${ }^{295}$ But the goal of giving people control over their own environmental destinies provides no basis for a sweeping presumption in favor of decentralized environmental decisionmaking.

293. I am indebted to my colleague Robert Ellickson for this example.

294. One of the sources of tension in the environmental policy process derives from the fact that what is understood to be harmful evolves over time. Elites often perceive and understand the changed circumstances first, but their judgment may be disregarded as unrepresentative. Education is therefore important to help build popular support for efforts to internalize new externalities.

295. In fact, there may be fewer opportunities for "exit" and "voice" at the state and local levels as well as reduced opportunities to recoup losses in some other policy domain. See Vicki Been, "Exit" as a Constraint on Land Use Exactions: Rethinking the Unconstitutional Conditions Doctrine, 91 ColuM. L. REV. 473, 509 (1991). 
Images of spirited New England town meetings where wellinformed citizens debate the destiny of their community bear little resemblance to today's state and local decisionmaking in general or environmental policymaking in particular. Generally, only those with a direct stake in local land use decisions appear at planning and zoning board meetings. On occasion, an issue will generate enough controversy for a public meeting to draw a crowd. But far more often decisions are made with little or no public participation or discussion. Similarly, at the state level, very few environmental issues generate sufficient media attention to produce any real public debate. Thus, decentralized decisionmaking may exclude from representation, albeit passively, the views of significant numbers of citizens.

Technical complexity may intersect with public choice issues to cast further doubt on the prospect that decentralization will produce better matches between environmental policy and citizen needs. In particular, knowledge of the existence of an environmental problem must be separated from knowledge of what to do about the harm. People often have the former without the latter. With regard to the deeper sort of knowledge relating to appropriate policy responses, the American citizenry often appears to be better informed about national environmental issues that have received widespread media coverage than state or local ones. ${ }^{296}$ In addition, it is useful to separate "first order" preferences (the desire that drinking water be safe to drink, for example) from "second order" preferences (benzene should be reduced to a level of seven parts per million, for example). People cannot be wrong about their first order preferences as these are value judgments. But there is no guarantee that members of the public will select optimal policy prescriptions in pursuit of their broader desires. In fact, the technical complexity of the regulatory process and the need to put competing values on a commensurate basis makes environmental decisionmaking especially obscure to the average citizen.

As a result of these complexities, environmental decisionmaking is particularly susceptible to special interest distortion. ${ }^{297}$ Rent-seeking be-

296. For example, a discussion of toxic contamination frequently makes little sense until described as a Love Canal-type problem.

297. See, e.g., Evan H. Caminker, State Sovereignty and Subordinacy: May Congress Commandeer State Officers to Implement Federal Law?, 95 COLUM. L. REv. 1001,1013 (1995) (describing state interests contributing to passage of Radioactive Waste Act); Stewart, Pyramids, supra note 7, at 1213-15; Michael C. Blumm, Public Lands: The Case Against Transferring BLM Lands to the States, NRLI NEws (Winter 1995), at 13 (stating that while "capture by the organized describes much federal land decisionmaking, it would reign unrestrained if the individual states were the decisionmakers"). 
havior undoubtedly affects national as well as state environmental policymaking, but there is no evidence that public decisionmaking is systematically more distorted at the federal than at state and local levels. ${ }^{298}$ Indeed, given general popular indifference to many state and local environmental decisions, as well as greater media attention to federal-level activities, one might suggest precisely the opposite. ${ }^{299}$

Federal interest group excesses tend to engender a corrective backlash $^{300}$ and spawn countervailing forces. ${ }^{301}$ In contrast, state and local environmental policy manipulation often goes unnoticed. Localized distortion is no doubt smaller and more incremental; but it is no less significant when summed, and perhaps is more insidious for its relative invisibility. Moreover, the interest group structure of these issues (environmental resource users concentrated on one side and a diffuse public on the other, for example) offers at least theoretical support for the suggestion that centralized decisionmaking will provide a more balanced playing field for the contending interests. ${ }^{302}$ The difficulty of mo-

298. But see Stewart, supra note 150 , at $340-42$ (arguing that these distortions at the federal level become magnified).

299. Even Business Week, hardly an apologist for a big federal government, recently suggested that "local bodies can be as bureaucratic and inefficient as the feds and often far more corrupt." Kevin Kelly et al., Power to the States, Bus. WK., Aug. 7, 1995, at 48, 50; see also FISCHEL, supra note 19, at 139 (arguing that local regulation is easiest to distort in support of special interests and against individual property owners); Robert Ellickson, Alternatives to Zoning, supra note 19, at 702 ("Studies have documented the lawlessness of zoning variance decisions in most communities."). Or as Robert Percival more modestly observes: " $[\mathrm{H}]$ istory demonstrates that state and local officials generally are too vulnerable to local economic and political pressures favoring development to be given exclusive responsibility for environmental protection." Percival, supra note 5, at 1178; see also Oliver A. Houck \& Michael Rolland, Federalism in Wetlands Regulation: A Consideration of Delegation of Clean Water Act Section 404 and Related Programs to the States, 54 MD. L. REv. 1242, 1309 (1995) (noting that, with regard to adequate wetlands protection, "state and local governments were not doing the job").

300. For example, a tremendous amount of criticism has been leveled at the Natural Resources Defense Council (NRDC) over Alar and at Greenpeace over the Brent Spar incident. See Better to Blunder than to Lie, THE INDEPENDENT, Sept. 6, 1995, at 16; Dwight Lee, Eco-hype Working Against the Cause?, WASH. TIMES, Nov. 22, 1992, at F3; Thomas Gale Moore, Environmental Kooks Dream Up Crises, S.F. CHRON., Sept. 14, 1992, at B3; Judith Perera, Greenpeace Faces Honesty Backlash, Inter Press Service, Sept. 5, 1995, available in LEXIS, News Library, INPRES File; Joseph Perkins, False Alarms: 'Environmentally Correct' Policies Often Are Based on Distorted Science, SAN Diego Union-TriB., July 2, 1993, at B5.

301. Consider the emergence of the Wise Use Movement in response to environmental groups. See also GregG EASTERBrook, A MOMENT ON THE EARTH (1995).

302. At the centralized level, environmental groups find it easier to reach critical mass and thereby to compete on more equal footing with industrial interests. See INTEREST GRoup POLITICS IN THE AMERICAN WeSt (Ronald J. Hrebenar \& Clive S. Thomas eds., 1987); INTEREST GROUP POLITICS IN THE SOUTHERN STATES (Ronald 
bilizing the public in many separate jurisdictions is well established. ${ }^{303}$ The technical complexity of environmental issues exacerbates the usual asymmetry because concentrated interests find it easier to assemble the data, information, and scientific analysis that carry great sway with regulators who are short on facts. Thus, whatever the asymmetry at the federal level, it is magnified at the state level.

Insofar as uninformed citizens do participate in making technically complex environmental regulatory judgements, their participation is of dubious value, and it cannot be assumed that their real interests are ultimately represented. In fact, popular indifference to the details of environmental policy debates may be rational. Ecological and public health issues are in many cases sufficiently complex that average voters reasonably conclude that the investment of time necessary to participate meaningfully in such debates exceeds any return that might be obtained. If this is the case, decentralized decisionmaking, which would entail more environmental voting, will be welfare reducing even if it is more democratic in some formalistic way. Given the nature of environmental policy questions, the answer to public choice problems may not be decentralized democracy, but rather expert resolution with vigorous legislative oversight. ${ }^{304}$ At the extreme end of the devolutionary spectrum, one could envision a system wherein citizens voted every night by remote control from their homes on environmental regulatory decisions. But seeking public guidance on how many parts per million of EBDC residue to permit on corn simply produces chaos and, as Justice Breyer argues, "[c]haos is not democracy." ${ }^{305}$ Representative democracy need not be undemocratic and may translate into decisions that better reflect the public's interest than purer or more direct forms of democracy. ${ }^{306}$

J. Hrebenar \& Clive S. Thomas eds, 1992). Of course, when costs are concentrated and benefits diffuse, NIMBY concerns may predominate, leading to distortions in the opposite direction. Land use decisions in particular, in which neighbors are often close at hand and well organized, are susceptible to NIMBY distortions because those who might benefit from a new land use (by having a shopping mall built, for example) have a less direct interest and therefore less incentive to participate in the decision process. point).

303. See supra note 79 (describing the abundant public choice literature on this

304. Justice Breyer, among others, has argued for expanded expert decisionmaking in the environmental realm. See STEPHEN BREYER, BREAKING THE VICIOUS CIRCLE: TOWARD EFFective Risk REgUlation 61-64 (1993); see also GraHAM \& WIENER, supra note 74.

305. BREYER, supra note 304 , at 73.

306. Whether every individual votes on every decision or policies are set at the most centralized level by the President, the critical issues remain the same: (1) How well informed is the decisionmaker? Are the technical inadequacies of the policy process minimized? (2) Does the decisionmaker take into account all of the relevant costs 
Doubt about the virtues of an entirely decentralized environmental regulatory regime does not imply that all decisions should be left to centralized experts. As a theoretical matter, however, the recent sweeping claims about the value of decentralization as a mechanism for improved self-determination in the environmental domain must be questioned. The better answer is a multitier regulatory structure capable of mixing and matching decision levels depending on the issue at hand.

\section{CONCLUSION}

This article should not be read as an argument in favor of centralized environmental regulation. It is intended simply to give pause to those who are driving for decentralized environmental regulation across the board. If this article accomplishes its purpose, it will lead to a reexamination of the presumption in favor of decentralized environmental regulation and to a recognition that the diversity of environmental problems we face demands a range of regulatory response strategies and levels of governmental activity. I hope, furthermore, that it will refocus the environmental policy reform debate from where we regulate to how we regulate. Policy progress depends on attention being concentrated on the real issues that create welfare losses: shaky scientific and analytic foundations for regulatory decisions, jurisdictional mismatches that skew cost-benefit calculations, and public choice distortions of the policymaking process.

Regulatory theory in the environmental domain must rest on an understanding of the unique nature of environmental problems and environmental regulation. Examined in light of the particular characteristics of ecological and public health harms - technical complexity, time lags, threshold effects, problems that overlap jurisdictional boundaries, and special interest policy distortions - and the specific regulatory failures that produce welfare losses, the hypothesized advantages of decentralization often diminish. In particular, while decentralization may in some circumstances improve the technical content of environmental policy decisions, frequently it will not. Devolution will help to improve environmental policymaking if it better aligns public values and regulatory outcomes, but the welfare losses from creating new interjurisdictional externalities and exposing the technical incapacity of many decentralized governmental units may overwhelm any representativeness gains obtained. Moreover, the prospect of public choice distortions of 
the policymaking process appear as severe or more severe at a decentralized level.

My call is not, however, for across-the-board centralization. Instead, I seek a middle road between the centralizers and the localizers in favor of a spectrum of regulatory entities. This diversity is structurally isomorphic to and simultaneously driven by the diversity of scales on which public health and ecological harms arise. While implicating a more complicated regulatory process, my argument for multiple tiers of governmental activity in the environmental domain (from local to international) responds to the fact that centralization, even if it allows jurisdictional externalities to be corrected, will not prove to be optimal in all cases. Sometimes the externalities corrected will be relatively small in comparison to the representativeness losses incurred by moving to a higher level of government. In other cases, regulatory failures arising at the more centralized level - internalities, diseconomies of scale, public choice distortions, the absence of competent authorities, and so on will outweigh the gains obtained by correcting a jurisdictional externality.

Ultimately, a regulatory approach that minimizes welfare loss for one type of governmental activity and one type of environmental problem may well lead to greater welfare losses in other regulatory activities or may exacerbate regulatory failures for other issues. The understanding that the appropriate level of environmental regulation fundamentally must be determined issue by issue, guided by nature and the geographic scope of the problem in question, also leads to a presumption against any presumption about the correct level of governmental intervention. The varying dimensions of community identity in the environmental realm add to the importance of having regulatory structures at local, state, national, and international levels. We can and should take advantage of hybrid environmental policy mechanisms that permit more subtle and refined forms of regulation capable of systematically minimizing the sum of the welfare losses from technical, structural, and public choice regulatory failures. 